\title{
EFICIÊNCIA DE INFECÇÃO E MULTIPLICAÇÃO DE ESTIRPES DE Xylella fastidiosa DE CITROS [Citrus sinensis (L.) Osbeck] E DE CAFEEIRO (Coffea arabica L.) EM INOCULAÇÕES CRUZADAS
}

\author{
SIMONE DE SOUZA PRADO
}

Dissertação apresentada à Escola Superior de Agricultura "Luiz de Queiroz", Universidade de São Paulo, para obtenção do título de Mestre em Ciências, Ârea de Concentração: Entomologia.

P I R A C I C A B A

Estado de São Paulo - Brasil

Outubro - 2003 


\section{EFICIÊNCIA DE INFECÇÃO E MULTIPLICAÇÃO DE ESTIRPES DE Xylella fastidiosa DE CITROS [Citrus sinensis (L.) Osbeck] E DE CAFEEIRO (Coffea arabica L.) EM INOCULAÇÕES CRUZADAS}

\section{SIMONE DE SOUZA PRADO}

Engenheiro Agrônomo

\section{Orientador: Prof. Dr. JOÃO ROBERTO SPOTTI LOPES}

Dissertação apresentada à Escola Superior de Agricultura "Luiz de Queiroz", Universidade de São Paulo, para obtenção do título de Mestre em Ciências, Área de Concentração: Entomologia.

P I R A C I C A B A

Estado de São Paulo - Brasil

Outubro - 2003 


\section{Dados Internacio nais de Catalogação na Publicação (CIP)}

DIVISÃO DE BIBLIOTECA E DOCUMENTAÇÃO - ESALQ/USP

\section{Prado, Simone de Souza}

Eficiência de infecção e multiplic ação de estipes de Xylella fastidiosa de citros[Citrus sinensis (L) Osbeck] e de cafeeiro (Coffea a rabica L) em inoculações cruzadas/ Simone de Souza Prado. -- Piracicaba, 2003.

$87 \mathrm{p}$.

Dissertação (mestrado) - - Escola Supeniorde Agricultura Luiz de Queiroz, 2003.

Bibliografia.

1. Bactéria fitopatogênica 2. Café 3. Clorose va riegada doscitros4. Fruti cítricas 5. Requeima I. Título

CDD 634.3

"Permitida a cópia total ou parcial deste documento, desde que citada a fonte - $\mathrm{O}$ autor" 


\begin{abstract}
A $\boldsymbol{D}_{\text {eus, }}$ por estar sempre presente, e aos meus avós Victorino e Alzira (in memorian), Jefferson e $\boldsymbol{M}$ aria do $\boldsymbol{C}$ armo por seus ensinamentos.
\end{abstract}

\title{
Agradeço
}

Aos meus pais $\boldsymbol{V}$ ITOR e $\boldsymbol{E}$ LZA,
irmãos VITOR e SILVIA, pelo
incentivo, atenção, compreensão e
carinho.

\section{Dedico}

$\boldsymbol{A}$ prender é descobrir aquilo que você já sabe.

$\boldsymbol{F}$ azer é demonstrar que você o sabe.

$\boldsymbol{E}_{\text {nsinar é lembrar aos outros que eles sabem tanto quanto você. }}$

Vocês são todos aprendizes, fazedores, professores!

$\boldsymbol{R}$ ichard $\boldsymbol{B}$ ach' 


\section{AGRADECIMENTOS}

Ao Prof. Dr. João Roberto Spotti Lopes, do Departamento de Entomologia, Fitopatologia e Zoologia Agrícola da Escola Superior de Agricultura "Luiz de Queiroz", da Universidade de São Paulo (ESALQ/USP), pela orientação, confiança e ensinamentos prestados no decorrer destes 5 anos e, principalmente pela amizade e apoio;

Aos Professores do Programa de Pós-Graduação do Departamento de Entomologia, Fitopatologia e Zoologia Agrícola (ESALQ/USP) pelos ensinamentos transmitidos e exemplos de profissionalismo, em especial ao Prof. Dr. Gilberto Casadei e ao Prof. Dr. Celso Omoto pela excelente contribuição decorrente da qualificação;

Ao José Francisco Garcia pelo apoio, incentivo, carinho, companheirismo, amizade que nem sempre foram retribuídos e, principalmente por preencher minha vida de amor e alegria;

À Maria Tereza Lopes ou "Matê" pelos ensinamentos sobre "a arte da biologia molecular", pelas discussões e sugestões prestadas e, principalmente pelo carinho, apoio, conselhos e excelente entrosamento nestes 5 anos de convivência e amizade;

À Teresinha Guistolin, pelas sugestões na execução e correção dos trabalhos e, principalmente pelos conselhos prestados, carinho e amizade;

Ao Prof. Dr. Luis Carlos Marchini e ao Prof. Dr. Celso Omoto pelo apoio e ensinamentos prestados na graduação; 
Ao Prof. Dr. Luís Eduardo Aranha Camargo (Fitopatologia - ESALQ/USP) e ao Prf. Dr. Décio Barbin (Depto. de Ciências Exatas - ESALQ/USP) pelas contribuições e conselhos nos trabalhos realizados na graduação e pela carta de recomendação enviada ao Programa de Pós-Graduação em Entomologia da ESALQ, as quais foram de grande valia;

À Prof ${ }^{a}$ Dr $^{a}$ Clarice Garcia Borges Demétrio (Depto de Ciências Exatas - ESALQ/USP) pela orientação e ensinamentos adquiridos na graduação e pelo auxílio prestado com as análises estatísticas, interpretação e discussão dos resultados em conjunto com o Mestre Adriano F. Borgatto na pós-graduação;

Ao Prof. Dr. Silvio Aparecido Lopes da Universidade de Ribeirão Preto - UNAERP e do pesquisador Luís Otávio Saggion Berian do Instituto Biológico de Campinas pelo fornecimento de alguns isolados de citros e de cafeeiro e pelas discussões no decorrer dos trabalhos;

À Coordenação de Aperfeiçoamento de Pessoal de Nível Superior (CAPES) pela concessão da bolsa de estudo, ao Fundo de Amparo à Pesquisa do Estado de São Paulo (FAPESP) e ao Programa Nacional de Pesquisa e Desenvolvimento do Café PNP\&D/Café - EMBRAPA, pelo apoio financeiro aos experimentos;

Ao Fundo de Defesa da Citricultura (Fundecitros), pelo fornecimento das mudas cítricas e pelo apoio financeiro;

Ao pesquisador Dr. Adalton Raga, do Instituto Biobogico de Campinas e à Cooperativa Garcafé pelo apoio na obtenção das mudas de café e ao Engenheiro Agrônomo José Otoboni da Garcafé, pela ajuda na coleta de alguns isolados de cafeeiro da bactéria;

À equipe de trabalho do Laboratório de Insetos Vetores: Charles, Danielle, Eduardo, Érica, Fernanda, Fernando, Flávio, Helen, Marcelo, Matê, Miguel, Paulo, Rodrigo, 
Rosângela, Teresinha e Thiago, pelo auxílio na realização deste trabalho e pela convivência harmoniosa que facilitou o trabalho;

Aos colegas de curso, Carolina Arruda, Cláudio Franco, Edmilson Silva, José Francisco Cruz, José Francisco Garcia, Márcio Tavares, Luciano Pacelli, Paulo Paiva e Uemerson Cunha, pela amizade e apoio durante o curso;

À analista de sistemas Regina de Moraes, aos secretários Ana Fabrette e João Forti e aos funcionários de campo Carlinhos, Dino e Tutu do setor de Entomologia (ESALQ/USP), pela amizade e apoio na condução dos trabalhos;

Ao pessoal do Laboratório de Patologia dos Insetos (ESALQ/USP), principalmente à Solange Aparecida Vieira pela ajuda na parte laboratorial;

À Augusta Moreti e ao Prof. Dr. Luis Carlos Marchini do Laboratório de Insetos Úteis pelas fotos das colônias;

Ao pessoal da Divisão de Biblioteca e Documentação (ESALQ/USP) e em especial às bibliotecárias Eliana Garcia, Kátia Ferraz e Silvia Zinsly pela atenção e revisão das normas para a elaboração desta dissertação. 


\section{SUMÁRIO}

Página

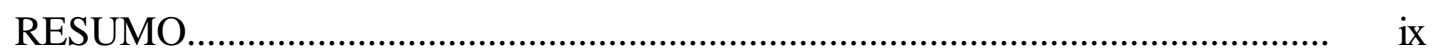

SUMMARY

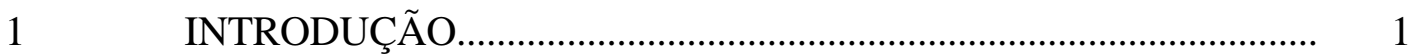

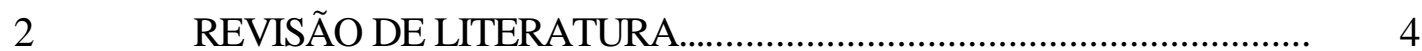

2.1 A bactéria Xylella fastidiosa, agente causal de muitas doenças de 4 plantas.

2.2 Principais doenças causadas por $X$. fastidiosa no Brasil......................... 6

2.2.1 Atrofia dos Ramos do Cafeeiro (ARC)................................................... 6

2.2.2 Clorose Variegada do Citros (CVC)...................................................... 7

2.2.3 Transmissão e epidemiologia de $X$. fastidiosa........................................ 9

2.2.4 Semelhanças entre a atrofia dos ramos do cafeeiro e a clorose 11 variegada do citros

2.3 Variabilidade entre as estirpes de X. fastidiosa ..................................... 12

2.3.1 Variações morfológicas das colônias de diferentes estirpes de $X .13$ fastidiosa.

2.3.2 Variações serológicas, genéticas e patogenéticas entre as diferentes 14 estirpes de $X$. fastidiosa

2.4 Métodos de detecção e quantificação de $X$. fastidiosa .............................. 17

2.4.1 Isolamento e cultivo bacteriano em meio de cultura................................. 18

2.4.2 Teste de "Polimerase Chain Reaction" (PCR) .......................................... 19

3 MATERIAL E MÉTODOS............................................................ 22

Obtenção e manutenção de plantas-teste............................................... 22 
3.2 Obtenção e preservação dos isolados de bactéria..................................... 23

3.3 Métodos de detecção e quantificação bacteriana utilizados nos 25 experimentos

3.3.1 Isolamento primário e quantificação bacteriana em meio de cultura 25 sólido

3.3.2 Teste de "Polimerase Chain Reaction"(PCR).......................................... 26

3.4 Teste de inibição de crescimento de Xylella fastidiosa por 28 homogeneizado de tecido cafeeiro.

3.5 Inoculação cruzada da estirpe de citros de X. fastidiosa em plantas de 29 citros e de café

3.6 Inoculação cruzada de estirpes de citros e de cafeeiro de X. fastidiosa 30 em plantas de citros e de café

3.7 Variações em morfologia e crescimento de colônias em meio de 33 cultura entre estirpes de $X$. fastidiosa de citros e de cafeeiro.

$4 \quad$ RESULTADOS E DISCUSSÃO...................................................... 34

4.1 Teste de inibição de crescimento de Xylella fastidiosa por 34 homogeneizado de tecido cafeeiro.

4.2 Inoculação cruzada da estirpe de citros de X. fastidiosa em plantas de 35 citros e de café

4.3 Inoculação cruzada de estirpes de citros e de cafeeiro de X. fastidiosa 37 em plantas de citros e de café.

4.4 Variações em morfologia e crescimento de colônias em meio de 65 cultura entre estirpes de $X$. fastidiosa de citros e de cafeeiro 


\section{EFICIÊNCIA DE INFECÇÃO E MULTIPLICAÇÃO DE ESTIRPES DE Xylella fastidiosa DE CITROS [Citrus sinensis (L.) Osbeck] E DE CAFEEIRO (Coffea arabica L.) EM INOCULAÇÕES CRUZADAS}

Autora: SIMONE DE SOUZA PRADO

Orientador: Prof. Dr. JOÃO ROBERTO SPOTTI LOPES

\section{RESUMO}

O trabalho teve por objetivo avaliar a capacidade de infecção e multiplicação de estirpes de Xylella fastidiosa de citros [Citrus sinensis (L.) Osbeck] e de cafeeiro (Coffea arabica L.) em inoculações cruzadas, para investigar a possibilidade de disseminação deste patógeno de pomares cítricos infectados para cafezais ou vice versa. As inoculações foram realizadas mecanicamente com um isolado (CCT6570) de $X$. fastidiosa proveniente de árvore cítrica com clorose variegada dos citros (CVC) e um isolado (CCT6756) de planta de café com sintomas de atrofia dos ramos do cafeeiro (ARC). Quatro concentrações de células de cada isolado, variando de $10^{3}$ a $10^{9}$ unidades formadoras de colônias (UFC) por $\mathrm{mL}$, foram inoculadas por agulha em citros e cafeeiro, para determinação de curvas de titulação e doses efetivas para infecção em cada combinação estirpe/hospedeiro. As plantas foram avaliadas por "polymerase chain reaction" (PCR) e isolamento em meio de cultura quanto à infecção por X. fastidiosa e população bacteriana, após 0,$5 ; 2 ; 4$ e 8 meses da inoculação. A estirpe de cafeeiro (ARC) de X. fastidiosa não colonizou citros nas concentrações de inóculo testadas. A inoculação da estirpe de citros (CVC) em cafeeiro resultou em baixas taxas de infecção, 
exigindo uma concentração de inóculo cerca de 10 vezes mais alta do que a necessária para a mesma taxa de infecção (25\%) em citros. A dose efetiva para infecção de $25 \%$ das plantas $\left(\mathrm{DE}_{25}\right)$ foi de $0,29 \times 10^{6}$ e $0,35 \times 10^{7} \mathrm{UFC} / \mathrm{mL}$ para as combinações (estirpe/hospedeiro) ARC/cafeeiro e CVC/citros, respectivamente. Já para a combinação heteróloga CVC/cafeeiro, a $\mathrm{DE}_{25}$ foi de $0,85 \times 10^{8} \mathrm{UFC} / \mathrm{mL}$, evidenciando a dificuldade de colonização de plantas de café pela estirpe de citros. A população bacteriana da estirpe de citros foi mais elevada em citros que em cafeeiro em todas as épocas de avaliação, embora a diferença tenha sido significativa apenas aos 2 meses após a inoculação. Um teste preliminar demonstrou que o método de isolamento primário envolvendo maceração de pecíolo foliar de cafeeiro infectado não inibe o crescimento de $X$. fastidiosa em meio de cultura, propiciando assim, uma estimativa confiável da população de células cultiváveis da bactéria em cafeeiro. Em caráter complementar, realizou-se um estudo de comparação morfológica de seis isolados de X. fastidiosa de citros com CVC e de seis isolados de cafeeiro com ARC, provenientes de diferentes localidades dos Estados de São Paulo e Minas Gerais. Não houve relação entre período de incubação ou diâmetro médio das colônias e o hospedeiro de origem dos isolados. Entretanto, as colônias dos isolados de cafeeiro apresentaram coloração opalescente e margens lisas, enquanto que as de citros mostraram-se mais convexas e escuras, com o centro áspero e margens onduladas, apresentando numerosos filamentos semelhantes a exopolissacarídeos. 


\section{INFECTION EFFICIENCY AND MULTIPLICATION OF CITRUS \\ [Citrus sinensis (L.) Osbeck] AND COFFEE (Coffea arabica $\mathbf{L}$.) \\ STRAINS OF Xylella fastidiosa IN CROSS INOCULATIONS}

Author: SIMONE DE SOUZA PRADO

Advisor: Prof. Dr. JOÃO ROBERTO SPOTTI LOPES

\section{SUMMARY}

The goal of this research was to evaluate infection efficiency and multiplication of citrus [Citrus sinensis (L.) Osbeck] and coffee (Coffea arabica L.) strains of Xylella fastidiosa after cross inoculations, in order to assess the potential for spread of this pathogen from infected citrus groves to coffee plantations and vice versa. Mechanical inoculations were carried out with a X. fastidiosa isolate (CCT6570) from a citrus tree showing citrus variegated chlorosis (CVC) and an isolate (CCT6756) from a coffee tree with coffee stem atrophy (CSA). Four cell concentrations of each isolate, ranging between $10^{3}$ a $10^{9}$ colony forming units (CFU) per $\mathrm{mL}$, were needle-inoculated in citrus and coffee plants, in order to determine titration curves and effective doses for infection in each strain/host combination. The rate of infected plants and the viable bacterial population were determined by polymerase chain reaction (PCR) and primary isolation in culture at 0.5, 2, 4 and 8 months after inoculation. The coffee (CSA) strain of $X$. fastidiosa did not colonize citrus in any of the inoculum concentrations tested. Cross inoculation of the citrus (CVC) strain in coffee resulted in low rates of infection and 
required an inoculum concentration 10 times higher than that necessary to obtain a similar $(25 \%)$ rate of infection in citrus. The effective dose for $25 \%$ infection $\left(\mathrm{ED}_{25}\right)$ was $0,29 \times 10^{6}$ and $0,35 \times 10^{7} \mathrm{CFU} / \mathrm{mL}$ for the homologous strain/host combinations, CSA/coffee and CVC/citrus, respectively. For the heterologous CVC/coffee combination, $\mathrm{ED}_{25}$ was higher $\left(0,85 \times 10^{8} \mathrm{CFU} / \mathrm{mL}\right)$, showing the difficulty of colonizatin of coffee plants by the citrus strain. Bacterial population of the citrus strain was higher in citrus than in coffee plants at all evaluation dates, although statistical differences were found only at 2 months after inoculation. A preliminary test showed that the primary isolation method used, which includes maceration of infected coffee leaf petioles, does not inhibit bacterial grow in culture, thus allowing reliable estimates of $X$. fastidiosa populations in coffee. Another study was carried out to compare colony morphology of six isolates of $X$. fastidiosa from citrus with CVC and six isolates from coffee with CSA, obtained from different localities in the States of São Paulo and Minas Gerais. There was no relationship between incubation period or average colony diameter and the original host of the isolates. However, colonies of the coffee isolates showed opalescent colour and flat margins, whereas the colonies of all citrus isolates were darker and more convex, with rugous center and ondulated margins presenting numerous filaments. 


\section{INTRODUÇÃO}

No Brasil, são conhecidas três doenças causadas pela bactéria fitopatogênica Xylella fastidiosa (Wells et al., 1987): a escaldadura das folhas da ameixeira (EFA) (Kitajima et al., 1975), que foi responsável pelo declínio da cultura nos Estados da região Sul a partir da década de 70 (Kitajima et al., 1981); a clorose variegada do citros (CVC), que vem comprometendo a produção de laranja, principalmente paulista (FNP 2003), após sua descoberta em 1987 (Rossetti et al., 1990); e a atrofia dos ramos do cafeeiro (ARC) ou requeima do cafeeiro (RC), descoberta em 1995 (Paradela Filho et al., 1995).

X. fastidiosa é uma bactéria gram-negativa, limitada aos vasos do xilema (Chagas et al., 1992), onde pode bloquear a translocação de seiva e apresentar-se distribuída de forma irregular (Hill \& Purcell, 1995b). Em citros, sua transmissão se dá através de cigarrinhas (Hemiptera: Cicadellidae) da subfamília Cicadellinae e até o momento foram identificadas 11 espécies vetoras (Lopes et al., 1996; Roberto et al., 1996; Krügner et al, 2000; Yamamoto et al., 2002). Foi após uma busca por hospedeiros alternativos que Paradela Filho et al. (1995) verificaram a ocorrência de X. fastidiosa também em plantas de café, causando redução do crescimento dos ramos (atrofia), encurtamento de internódios, ocorrência de folhas pequenas, cloróticas e deformadas, redução na quantidade e no tamanho dos frutos, e morte dos ramos laterais (Lima et al., 1996; Paradela Filho et al., 1997). A ARC encontra-se disseminada nas principais regiões produtoras de café dos Estados de Minas Gerais (Takatsu et al., 2001), São Paulo (Lima et al., 1996) e Paraná (Carvalho et al., 2000), o que sugere uma antiga associação de $X$. fastidiosa com o cafeeiro, possivelmente como um organismo endofítico (Barbosa, 
2003). Apesar da importância desta doença em cafeeiro, pouco se sabe a respeito de sua transmissão e epidemiologia, o que dificulta o seu manejo.

Existem semelhanças intrigantes entre a ARC e a CVC, além das duas doenças serem causadas pela mesma espécie de bactéria. Assim como a CVC, a ARC foi relatada originalmente na região noroeste do Estado de São Paulo e ocorre freqüentemente perto de pomares de laranja com a CVC (Paradela Filho et al., 1995). Recentemente, Marucci (2003) constatou a transmissão de X. fastidiosa para o cafeeiro pelas espécies Bucephalogonia xanthophis (Berg), Dilobopterus costalimai Young, Homalodisca ignorata Melichar e Oncometopia facialis (Signoret), que são vetoras em citros. Como as duas doenças possuem vetores em comum, existe potencial para infecção cruzada de $X$. fastidiosa em citros e cafeeiro. Além disso, Li et al. (2001) observaram que um isolado de citros da bactéria $X$. fastidiosa causou a doença ARC quando inoculado em plantas de café, induzindo sintomas semelhantes aos de um isolado de cafeeiro. Trabalhos anteriores têm mostrado que isolados de citros de $X$. fastidiosa são morfologicamente e serologicamente semelhantes a isolados de plantas de café (Paradela Filho et al., 1997; Lima et al., 1998) e apresentam alta similaridade genética (Costa et al, 2000).

Paradela Filho et al. (1995) em Li et al. (2001) postularam que o agente causal da CVC originou-se a partir de uma população pré-existente de $X$. fastidiosa em plantas de café. Esta hipótese é reforçada pelo fato de cafezais e pomares terem sido cultivados lado a lado na região de origem das duas doenças (Paradela Filho et al., 1995) e pela existência de cigarrinhas vetoras de $X$. fastidiosa que freqüentam ambas as culturas (Lopes et al., 1998), o que teria possibilitado a inoculação cruzada da bactéria até a seleção natural de um isolado patogênico a citros. Além do aspecto evolutivo, esta questão tem importância na epidemiologia e controle de ambas as doenças, pois pomares cítricos infectados podem estar atuando como fonte de inóculo para a disseminação de $X$. fastidiosa para cafezais ou vice versa.

Buscando-se investigar esta hipótese, a presente pesquisa teve por objetivo avaliar comparativamente a capacidade de infecção, sobrevivência e multiplicação de isolados de $X$. fastidiosa causadores de CVC e de ARC após sua inoculação mecânica 
em plantas de café e citros, determinando-se a dose bacteriana efetiva (DE) necessária para o estabelecimento das infecções. Como um parâmetro complementar para a caracterização das duas estirpes, além da capacidade de infecção cruzada em citros e cafeeiro, foram comparados vários isolados de citros e de cafeeiro quanto ao crescimento em meio de cultura e morfologia de colônias. 


\section{REVISÃO DE LITERATURA}

\subsection{A bactéria Xylella fastidiosa, agente causal de muitas doenças de plantas}

$X$. fastidiosa é uma bactéria gram-negativa, obrigatoriamente aeróbica, possuindo forma de bastonete com 0,25 a $0,35 \mu \mathrm{m}$ de diâmetro por 0,9 a 3,5 $\mu \mathrm{m}$ de comprimento, apresenta uma parede celular enrugada e crescimento ótimo entre 26 e $28^{\circ} \mathrm{C}$ e em pH entre 6,5 a 6,9 (Wells et al., 1987). Esta bactéria encontra-se limitada aos vasos do xilema de seus hospedeiros (Mollenhauer \& Hopkins, 1976), podendo bloquear o movimento de água e a translocação de seiva no seu interior, e distribuindo-se de forma irregular nesses vasos (Hill \& Purcell, 1995b). Além do xilema das plantas, esta bactéria pode ser encontrada no lúmen do canal alimentar de insetos vetores, que podem ser cigarrinhas das famílias Cicadellidae (subfamília Cicadellinae) ou Cercopidae (Purcell \& Hopkins, 1996).

Esta bactéria coloniza inúmeras espécies de plantas arbóreas, perenes e herbáceas, que podem ou não manifestar sintomas (Hopkins, 1989; Hopkins \& Adlerz, 1988). As plantas hospedeiras suscetíveis são principalmente, árvores frutíferas de importância econômica, as quais são propagadas vegetativamente, propiciando a disseminação do patógeno por mudas e borbulhas infectadas (Sempionato et al., 1997).

$X$. fastidiosa foi originalmente associada à doença "Pierce's disease" (PD) de videira (Vitis vinifera L.) na Califórnia, EUA (Goheen et al., 1973; Hopkins \& Mollenhauer, 1973) e recebeu este nome por apresentar crescimento lento quando isolada em meio de cultura (Davis et al., 1978; Wells et al., 1987). Além de PD em videira, a bactéria $X$. fastidiosa causa as doenças denominadas "alfafa dwarf" (AD) em alfafa (Medicago sativa L.) (Goheen et al., 1973), "almond leaf scorch" (ALS) em 
amendoeira (Prunus amygdalus Batsch) (Mircetich et al., 1976), "phony peach disease" (PPD) em pessegueiro [P. persica (L.) Batsch] (Hopkins \& Mollenhauer, 1973), "pear leaf scorch" (PS) em pereira [Pyrus pyrifolia (N.L.Burm.) Nakai] (Leu \& Su, 1993), "elm leaf scorch" (ELS) em olmo (Ulmus americana L.) (Hearon et al., 1980), "oak leaf scorch" (OLS) em carvalho (Quercus rubra L.) (Hearon et al., 1980), "mulberry leaf scorch" (MLS) em amoreira (Morus rubra L.) (Hearon et al., 1980), "sycamore leaf scorch" (SLS) em plátano (Platanus occidentalis L.) (Hearon et al., 1980), “oleander leaf scorch" (OS) em espirradeira (Nerium oleander L.) (Purcell \& Saunders, 1999), "pecan bacterial leaf scorch" (PBLF) em nogueira-pecan (Carya illinoinensis) (Sanderlin \& Heyderich-Alger, 2000), "citrus variegated chlorosis" ou clorose variegada do citros (CVC) em citros [Citrus sinensis (L.) Osbeck] (Rossetti et al., 1990), "coffee stem atrophy" (CSA) ou atrofia dos ramos do cafeeiro (ARC) em cafeeiro (Coffeea arabica L.) (Paradela Filho et al.,1995) e "plum leaf scald" (PLS) ou escaldadura das folhas da ameixeira (EFA) em ameixeira (P. saliciana Lindl.) (Kitajima et al., 1975), sendo estas três últimas de importância no Brasil.

$X$. fastidiosa infecta e coloniza uma grande gama de plantas hospedeiras sem causar doença (Freitag, 1951; Hopkins \& Adlerz, 1988; Raju et al., 1983). Alguns hospedeiros herbáceos de rápido desenvolvimento, tais como o fumo (Nicotiana tabacum) (Lopes et al., 2000) e a vinca (Catharanthus roseus) (Monteiro et al., 2001), mostram sintomas em um curto período de tempo sendo por isso utilizados em estudos das interações planta-patógeno-vetor. Em plantas invasoras presentes em pomares cítricos e em cafezais, a bactéria pode ocorrer, multiplicar-se e movimentar-se de forma sistêmica (Leite et al., 1997; Lopes et al., 2003), mas a importância dessas plantas como fonte de inóculo do patógeno para a disseminação da CVC é questionável.

$X$. fastidiosa parece estar associada ao clima, já que ocorre principalmente nas áreas tropicais e subtropicais do continente americano (Hopkins, 1989). Existem relatos desta bactéria causando doença em amendoeira na Índia (Jindal \& Sharma, 1987), em pereira em Taiwan (Leu \& Su, 1993) e em videira na Europa (Berisha et al., 1998). 


\subsection{Principais doenças causadas por $X$. fastidiosa no Brasil}

\subsubsection{Atrofia dos Ramos do Cafeeiro (ARC)}

As constantes procuras por possíveis hospedeiros alternativos de $X$. fastidiosa levaram a detecção e ao primeiro relato desta bactéria em vasos do xilema de plantas de café provenientes das regiões de Macaubal e São José do Rio Preto (Paradela Filho et al., 1995).

X. fastidiosa foi originalmente detectada em cafeeiro através dos métodos de DIBA ("dot immunobinding assay"), ELISA ("enzyme-linked immunosorbent assay"), Western blot e PCR ("polymerase chain reaction"). Posteriormente, Lima et al. (1996) e Paradela Filho et al. (1997) observaram-na por meio de microscópio ótico.

Plantas de café infectadas com $X$. fastidiosa apresentam encurtamento de internódios, redução do crescimento dos ramos (atrofia), queda prematura das folhas mais velhas, ocorrência de tufo de folhas pequenas, cloróticas e deformadas, além de redução na quantidade e tamanho dos frutos, e secamento dos ramos laterais, que ficam com o aspecto de uma "vareta" seca (Lima et al., 1998; Paradela Filho et al., 1997). Alguns sintomas como o amarelecimento e crestamento das folhas não são freqüentes a ponto de caracterizar a doença (Takatsu et al., 2001).

São sugeridos dois nomes para a doença em cafeeiro: "Atrofia dos Ramos do Cafeeiro" (ARC) ou "Coffee Stem Atrophy" (CSA) devido a má formação (atrofia) e desfolhamento dos ramos (Prado et al., 2000; Li et al., 2001) e "Requeima do Cafeeiro" (RC) ou "Coffee Leaf Scorch" (CLS), devido ao sintoma de requeima nos bordos das folhas (Li et al., 2001; Lima et al., 1998).

Segundo Matiello et al. (1998), a ARC tem sido observada em todas as regiões produtoras de café do Brasil, no entanto, não se sabe ao certo se está causando prejuízos às lavouras cafeeiras. Levantamentos realizados em cafezais dos estados produtores demonstram que a bactéria está presente na maioria das áreas cultivadas do Estado de São Paulo (Lima et al., 1996) e Triângulo Mineiro (Takatsu et al., 2001), tendo sido detectada em vários cultivares de Coffea arabica (Mundo Novo, Catuaí Amarelo e 
Vermelho), além do Coffea canephora (Robusta), sendo provavelmente mais bem distribuída geograficamente que as doenças em citros (CVC) e em ameixeira (EFA).

Segundo Paradela Filho et al. (1997), a população da bactéria nas plantas de café varia de acordo com a época do ano, sendo menor de janeiro a março. No entanto, os sintomas são mais evidentes durante o inverno, especialmente durante os períodos de estresse hídrico, provavelmente devido a uma maior população da bactéria (Lima et al., 1998). Já a presença de X. fastidiosa em plantas de café aparentemente sadias, segundo Barbosa (2003), seria explicada pela possibilidade de a bactéria atuar como um organismo endofítico nas plantas de café, e que somente uma condição de estresse ambiental, como hídrico, nutricional e de temperatura, proporcionaria a expressão dos sintomas.

A presença de $X$. fastidiosa em plantas de café tanto em regiões adjacentes a pomares cítricos infectados com a bactéria, quanto em regiões onde não existem pomares cítricos e, portanto não ocorre CVC, levanta a hipótese de que a disseminação possa ter ocorrido das plantas de café para as plantas de citros, uma vez que algumas das cigarrinhas vetoras da CVC também são observadas se alimentando nas plantas de café (Li et al., 2001; Lima et al., 1996; Prado et al., 2000). Apesar da importância desta doença, pouco se sabe a respeito de sua transmissão e epidemiologia, o que dificulta o manejo da doença.

\subsubsection{Clorose Variegada do Citros (CVC)}

O primeiro relato de X. fastidiosa (Wells et al., 1987) em vasos do xilema de plantas de citros ocorreu em 1987 em pomares da região do norte e do sudoeste dos Estados de São Paulo e Minas Gerais, respectivamente (Rossetti et al., 1990). Hoje a CVC, popularmente conhecida de "Amarelinho", está disseminada pelas principais regiões produtoras de citros do país, inclusive em Sergipe (Leite Júnior et al., 1996) e Bahia (Santos Filho et al., 1999). Há relatos de sua ocorrência também na Argentina (Contreras, 1992) e Costa Rica (Rodriguez et al., 2001). 
A primeira observação de $X$. fastidiosa em vasos do xilema de plantas cítricas foi por meio de microscopia eletrônica (Chagas et al., 1992; Rossetti et al., 1990), Posteriormente, esta bactéria foi isolada de plantas de citros sintomáticas e reinoculada em plantas sadias, fechando-se os postulados de Koch (Chang et al., 1993; Lee et al., 1993). Os métodos de ELISA (Leite Júnior \& Leite, 1991), DIBA (Beretta et al., 1993), Westen blot e PCR também foram utilizados para a detecção da bactéria (Lima et al., 1998).

O principal sintoma da presença de $X$. fastidiosa nas plantas de citros é a clorose foliar, similar a causada pela deficiência de zinco. Folhas mais velhas tornam-se cloróticas devido a presença da bactéria que já se desenvolveu e habitou os vasos do xilema. Na superfície abaxial das folhas surgem lesões de cor marrom-clara que correspondem às áreas cloróticas amarelas na superfície adaxial. Estas áreas cloróticas podem tornar-se marrom-escuras ou necróticas, chegando muitas vezes, a coalescer (Rossetti et al., 1990).

Plantas severamente atacadas apresentam atrofia e diminuição da copa, muitas vezes adquirindo aspecto amarelado, podendo ainda ocorrer queda de folhas, morte de ponteiros, encurtamento de internódios e aumento de brotações nas gemas dos ramos afetados (Laranjeira, 1997). Os frutos de árvores afetadas são pequenos e duros, apresentam alto conteúdo de açúcar, amadurecem precocemente e sua produção é reduzida (Huang \& Chiaradia, 1998; Rossetti et al., 1990). Esses frutos, por serem de baixa qualidade, não são aceitos no mercado de frutas frescas, nem nas indústrias de processamento de suco (Huang \& Chiaradia, 1998).

A incidência da CVC encontra-se estável no Estado de São Paulo desde de 1999, oscilando entre 34\% e 36\%. Em 2002 ocorreu um aumento para 38,28\%, que não foi significativo. No entanto, a severidade da doença e conseqüentemente os prejuízos de perda da produção têm aumentando com o passar dos anos, uma vez que existe uma tendência natural das plantas com sintomas mais leves atingirem para estágios mais avançados da doença (Raio, 2002).

O sucesso na contenção desta doença tem sido devido ao programa de manejo adotado, que envolve a redução do inóculo da CVC, através de poda e/ou erradicação de 
plantas sintomáticas, o controle das cigarrinhas transmissoras e, principalmente, a utilização de mudas certificadas e sadias para a instalação dos pomares (Carlos et al., 1997; Lopes, 1996).

\subsubsection{Transmissão e epidemiologia de $X$. fastidiosa}

A ampla disseminação da CVC no Brasil ocorreu principalmente devido à comercialização deliberada de mudas e borbulhas contaminadas com a bactéria $X$. fastidiosa, principalmente para áreas distantes (Lima et al., 1996; Sempionato et al., 1997). A existência de insetos vetores contribuiu para o aumento da doença dentro dos pomares (Lopes et al., 1996; Roberto et al., 1996), após o plantio de mudas infectadas.

A doença que $X$. fastidiosa causa em plantas de café ainda tem sido pouco estudado, mas segundo Barbosa (2003), a bactéria está disseminada nos cafeeiros das regiões Sul e Zona da Mata de Minas Gerais, tanto em plantas com sintomas característicos de atrofia dos ramos quanto em plantas aparentemente sadias. Nesse mesmo estudo, a doença foi constatada em cafeeiros com mais de 10 anos em uma proporção inferior a $50 \%$ de plantas infectadas, e a distribuição espacial destas plantas foi caracterizada principalmente, como em reboleiras.

Estudos epidemiológicos para a CVC mostram que a disseminação ocorre principalmente de forma secundária, ou seja, de citros para citros dentro dos pomares, sendo que as principais fontes de inóculo são pomares vizinhos infectados (Laranjeira et al., 1998) e o período de maior disseminação da doença ocorre quando a temperatura média anual e a precipitação se elevam (Pereira, 2000).

Os insetos relatados como vetores de $X$. fastidiosa são insetos sugadores que se alimentam em vasos do xilema de uma vasta gama de plantas hospedeiras (Hopkins et al., 1991) e pertencem às famílias Cicadellidae (subfamília Cicadellinae), Cercopidae (Frazier, 1965; Turner \& Pollard, 1959) e Cicadidae (Paião et al., 2002). Até o momento, as cigarrinhas confirmadas como vetoras de $X$. fastidiosa em citros são: Acrogonia citrina Marucci \& Caviochioli, D. costalimai, O. facialis, B. xanthophis, Plesiommata corniculata (Young), Acrogonia virescens (Metcalf), Ferrariana trivittata 
(Signoret), H. ignorata, Macugonalia leucomelas (Walker), Parathona gratiosa (Blanchard) e Sonesimia grossa (Signoret) (Krügner et al., 2000; Yamamoto et al., 2002).

Embora muitas cigarrinhas possam atuar como vetores de $X$. fastidiosa, a eficiência de aquisição e de transmissão pode variar em função da espécie envolvida, de sua afinidade (atratividade e aceitabilidade) com a planta hospedeira (Marucci, 2003; Purcell \& Hopkins, 1996) e do local de alimentação nas plantas (Lopes, 1996).

As cigarrinhas adultas, uma vez infectadas, podem transmitir X. fastidiosa, por toda sua vida (Severin, 1949), devido à capacidade desta bactéria se multiplicar nos vetores (Hill \& Purcell, 1995a). Apenas na fase de ninfa ocorre perda da capacidade de transmissão da bactéria, devido às ecdises (Purcell \& Finlay, 1979), quando ocorre a troca da cutícula do aparelho bucal e tubo digestivo anterior (estomodéu), onde a bactéria se aloja (Purcell, 1994). Aparentemente, a aquisição de X. fastidiosa por cigarrinhas ocorre somente mediante alimentação dos indivíduos em plantas infectadas, não tendo sido verificada a passagem da bactéria por transmissão transovariana (Freitag, 1951).

Na transmissão da estirpe de videira da bactéria X. fastidiosa por Graphocephala atropunctata (Signoret), verificou-se que a cigarrinha pode adquirir a bactéria em apenas 1 hora de alimentação em uma planta infectada, e transmiti-la para plantas sadias imediatamente após a aquisição, sem haver período latente no vetor (Purcell \& Finlay, 1979). G. atropunctata possui alta eficiência de transmissão (90\%) em videira quando comparada com as cigarrinhas em citros, cujas eficiências variam de 1,3\% para $O$. facialis a 11,7\% para B. xanthophis (Krügner et al., 2000). Marucci (2003) observou que $H$. ignorata é mais eficiente na transmissão de $X$. fastidiosa para citros do que $B$. xanthophis e $O$. facialis, mas não diferiu de D. costalimai .

A transmissão de $X$. fastidiosa para plantas de café também ocorre através de insetos vetores e de modo semelhante ao observado para citros, uma vez que Marucci (2003) confirmou a transmissão de X. fastidiosa pelas espécies B. xanthophis, D. costalimai, H. ignorata e O. facialis para o cafeeiro, com eficiências variáveis de 2,2\% para H. ignorata a $20 \%$ para D. costalimai. 
A baixa eficiência de transmissão pelos insetos vetores em citros pode estar relaciona à baixa população da bactéria nas plantas (Almeida et al., 2001), pois populações da estirpe de videira menores que $10^{6}$ a $10^{7} \mathrm{UFC} / \mathrm{g}$ de tecido reduziram a eficiência de transmissão dos insetos vetores (Hill \& Purcell, 1997).

Em pomares cítricos, além de plantas de laranja infectadas com a bactéria, plantas invasoras também podem servir de reservatório de $X$. fastidiosa para aquisição e transmissão pelo inseto vetor para plantas de citros. Lopes et al. (2003) relataram que, após inoculações mecânicas, a população da bactéria nas plantas invasoras variou de $10^{4}$ a $10^{6} \mathrm{UFC} / \mathrm{g}$ de tecido, concentração semelhante à encontrada em folhas sintomáticas de citros utilizadas como fonte de $X$. fastidiosa em experimentos de transmissão, e relatadas em plantas de citros em outro estudo (Almeida et al., 2001).

Após a descoberta de $X$. fastidiosa em cafeeiro e que as cigarrinhas presentes nos pomares e nos cafezais transmitem a bactéria, houve preocupação com a disseminação entre culturas, pois cafezais infectados em áreas adjacentes a pomares de laranja podem estar servindo como fonte de inóculo, onde os vetores podem adquirir a bactéria e transmiti la para plantas de citros (Paradela Filho et al., 1997).

\subsubsection{Semelhanças entre a atrofia dos ramos do cafeeiro e a clorose variegada do citros}

A ARC e a CVC apresentam semelhanças intrigantes, além de serem causadas pela mesma espécie de bactéria. Da mesma forma que a CVC, a ARC foi relatada pela primeira vez na região noroeste do Estado de São Paulo, em cafezais localizados próximo a pomares de laranja com a CVC (Paradela Filho et al., 1995). Aparentemente, as duas são transmitidas pelos mesmos insetos vetores (Lima et al., 1996; Lopes et al., 1998; Prado, 2000). Recentemente, Marucci (2003) verificou a transmissão de $X$. fastidiosa para o cafeeiro pelas espécies B. xanthophis, D. costalimai, H. ignorata e $O$. facialis, que são vetores importantes em citros. 
Li et al. (2001) observaram que um isolado da estirpe de citros de X. fastidiosa, quando inoculado mecanicamente em plantas de café, induziu sintomas semelhantes ao de um isolado da estirpe de cafeeiro da bactéria.

A estirpe de cafeeiro foi mais facilmente detectada pelos testes de ELISA, PCR e cultura que a estirpe de citros inoculada em plantas de café, sugerindo que os níveis populacionais da estirpe de cafeeiro nas plantas de café (combinação homóloga) sejam mais altos que os da estirpe de citros ( $\mathrm{Li}$ et al., 2001). Isto é consistente com a observação de multiplicação diferencial de $X$. fastidiosa após sua inoculação em hospedeiros com suscetibilidade variável (Fry \& Milholland, 1990). Tem sido relatado que a estirpe de citros é morfologicamente, serologicamente e geneticamente semelhante à estirpe de cafeeiro (Costa et al., 2000; Lima et al., 1998; Rosato et al., 1998). Nenhuma diferença foi observada entre os isolados de citros e de cafeeiro, já que as suspensões bacterianas reagiram com antissoro produzido contra $X$. fastidiosa isolada de plantas de citros (Paradela Filho \& al., 1997), e foi constatada a existência da mesma banda depois da amplificação por PCR com oligonucleotídeos específicos para a estirpe de citros (Lima et al., 1998; Pooler \& Hartung, 1995).

\subsection{Variabilidade entre as estirpes de $X$. fastidiosa}

Todas as estirpes de $X$. fastidiosas têm sido consideradas homogênicas e classificadas como uma espécie única (Wells et al., 1987). Entretanto, as variações existentes na gama de hospedeiros, nível de "fastidiosidade", homologia de DNA, patogenicidade, características moleculares e padrões de crescimento em meio de cultura entre os isolados, sugerem a existência de subespécies ou patovares (Hendson et al., 2001; Purcell \& Hopkins, 1996). Por outro lado, essa divisão em subespécies é contestada pelo fato de algumas estirpes conseguirem produzir sintomas semelhantes à de outra estirpe em um hospedeiro comum (Hopkins \& Purcell, 2002).

Segundo Hopkins \& Purcell (2002), muitas estirpes de X. fastidiosa que causam doenças em plantas, ainda não foram testadas quanto à habilidade em causar doenças em outros hospedeiros, além daqueles que foram originalmente isoladas. Estes testes de 
patogenicidade têm grande utilidade em estudos de ecologia, epidemiologia e controle de doenças (Hopkins \& Purcell, 2002), já que a compreensão da diversidade das estirpes, de como elas selecionam seus hospedeiros e qual o seu papel ecológico na vegetação nativa, poderá auxiliar a prevenir o desenvolvimento de novas doenças causadas por $X$. fastidiosa (Chen et al., 2002).

\subsubsection{Variações morfológicas das colônias de diferentes estirpes de $X$. fastidiosa}

A estirpe de $X$. fastidiosa de ameixeira desenvolveu ora colônias circulares com margens onduladas, ora colônias ovais com margens lisas, mas geralmente se apresentaram circulares e elevadas ou rentes à superfície do meio BCYE, 8 a 16 dias após a incubação. $\mathrm{O}$ diâmetro das colônias variou de 0,1 a 0,9 mm depois de 3 semanas (Raju et al., 1982).

Para a estirpe de vinca isolada nos meios PW, SC e BCYE, as colônias se apresentaram circulares com margens inteiras, convexas, de coloração branca opalescente com o diâmetro variando de 0,7 a 1,0 mm (Davis et al., 1983).

$\mathrm{Na}$ estirpe de pessegueiro, as colônias primárias isoladas no meio BCYE foram translúcidas, restritas, rentes ao meio e circulares, com margens distintas e diâmetro variando de 0,1 a 0,4 mm (Wells et al., 1983). Posteriormente, Wells et al. (1987) descreveram o gênero Xylella e observaram a existência de dois tipos de colônias que se caracterizaram como: a) convexas e abauladas, de coloração opalescente lisa com as margens inteiras; ou b) apresentando o centro áspero e irregular com margens finas e onduladas.

Um estudo com as estirpes de videira e de amendoeira mostrou que as colônias decorrentes do isolamento nos meios XF-26, CS20 e PD2 apresentaram coloração branca e opalescente e o diâmetro variando de 0,1 a 0,35, 0,04 a 0,43 e 0,08 a 0,40 mm, respectivamente, após 7 dias de incubação (Chang \& Donaldson, 1993).

A estirpe de citros apresentou um período de incubação de 5 dias no meio PW e de 7 a 10 dias nos meios PD2 e CS20 (Chang et al., 1993). Em isolamento primário, Almeida et al. (2001) observaram um período de incubação de 7 a 8 dias para os 
isolados da estirpe de citros nos meios PW e PWG e de 14 a 15 dias no meio BCYE, com diâmetro de colônia variando de 0,46 a 1,40 mm nos diferentes meios.

No primeiro relato da bactéria $X$. fastidiosa em pereira em Taiwan, Leu \& Su (1993) observaram que a forma geral das colônias foi convexa, redonda, branca leitosa com a margem lisa, e medindo de 0,1 a $0,2 \mathrm{~mm}$ de diâmetro depois de 14 dias de incubação a $30^{\circ} \mathrm{C}$ no meio PD2.

O isolamento da estirpe de cafeeiro realizado por Lima et al. (1998) revelou colônias circulares, em forma de cúpula, e de coloração branca com o diâmetro variando de 0,5 a 1,5 mm, 30 dias após o isolamento em meio SPW.

Em geral, $X$. fastidiosa tem sido isolada de tecidos sintomáticos em meios específicos e é caracterizada por ser de crescimento lento em meio de cultura e apresentar colônias pequenas e opalescentes (Banks et al., 1999).

\subsubsection{Variações serológicas, genéticas e patogenéticas entre as diferentes estirpes de X. fastidiosa}

Embora estudos de patogenicidade demonstram haver certas afinidades entre algumas estirpes de X. fastidiosa surgerindo a formação de diferentes grupos, estas mesmas estirpes quando comparadas geneticamente formam outros grupos e demonstram a variabilidade existente entre as diferentes estirpes em relação ao método de diferenciação utilizado.

Hewitt \& Houston (1941) observaram que a incidência de X. fastidiosa em vinhedos era maior em áreas adjacentes a plantações de alfafa que apresentavam a bactéria, diminuindo à medida que a distância entre as plantações infectadas aumentava. Posteriormente, Davis et al. (1980) relataram que as doenças em videira, amendoeira e alfafa são causadas pela mesma estirpe de X. fastidiosa, e, Chen et al. (1992) confirmaram, através da técnica de RFLP ("restriction fragment length polymorphism"), que as três estirpes apresentam alta similaridade genética $(>0,80)$, formado o grupo de videira. A estirpe de videira é patogenicamente distinta da estirpe de vinca (Davis et al., 
1983), que está provavelmente mais próxima das estirpes de pessegueiro e de ameixeira (Chen et al., 1992).

Wells et al. (1981b), observaram que a estirpe de pessegueiro também produz sintomas de escaldadura das folhas semelhantes aos da doença PLS quando inoculada em plantas de ameixa. Posteriormente, Raju et al. (1982) e Leite Júnior et al. (1998) também observaram resultados semelhantes.

Plantas de amendoeira não mostraram sintomas de ALS quando inoculadas com a estirpe de ameixeira, mas sim quando inoculadas com a estirpe de videira. Com isso, a estirpe de ameixeira pode ser distinguida da estirpe de videira serologicamente por ELISA ou pela falta de patogenicidade em amendoeira (Wells et al., 1981a). Também as estirpes de oleandro e de videira infectam plantas de amendoeira (Hopkins \& Purcell, 2002), mas a estirpe de oleandro não infecta videira e vice-versa (Purcell et al., 1999). Sherald (1993) observou que a inoculação cruzada entre as estirpes de olmo e plátano não resultou em doença nos hospedeiros heterólogos.

Estudos genéticos revelaram alto nível de homologia de DNA entre as estirpes de ameixeira, pessegueiro, vinca e videira (Kamper et al., 1985), embora tenha sido observado que a estirpe de pessegueiro não causa doença em videira e vice-versa (Hopkins \& Adlerz, 1988). Já estirpe de pereira apresenta baixa homologia $(<20 \%)$ em relação às estirpes de ameixeira, pessegueiro, vinca, videira (Kamper et al., 1985), alfafa (Leu \& Su, 1993) e outras (Metha \& Rosato, 2001).

Chen et al. (1995), através da técnica de RAPD ("random amplified polymorfic DNA"), observaram alto grau de similaridade entre sete estirpes de videira $(>0,93)$ e sete de carvalho (> 0,96$)$, e uma baixa similaridade $(0,44)$ quando comparadas às estirpes de ameixeira e de vinca.

Hartung et al. (1994), dependendo do teste utilizado, encontraram relação serológica entre as estirpes de citros, ambrósia americana (Ambrosia sp.), carvalho, videira e amendoeira. Também constataram similaridade entre as estirpes de videira, olmo e amoreira e entre as estirpes de olmo, ameixeira e citros. Pooler et al. (1995) distinguiram cinco grupos: a) formado pela estirpe de citros, b) formado pelas estirpes de olmo e de ameixeira, c) formado pelas estirpes de videira e de ambrósia americana, d) 
formado pela estirpe de amendoeira e e) formado pela estirpe de amoreira. Enquanto que Minsavage et al. (1994) observaram que as estirpes de citros e videira pertencem ao mesmo grupo.

Beretta et al. (1997) obtiveram três grupos diferentes, o de citros, o de amoreira e um outro formado pelas estirpes de videira, ambrósia americana, amendoeira e carvalho. Através da análise da região 16S rDNA por RAPD, Chen et al. (2002) observaram que os grupos de videira e de citros apresentaram uma estabilidade menor, e a estirpe de amoreira foi incluída no grupo de videira.

Hendson et al. (2001) distinguiram três grupos, o de oleandro, o de pessegueiro e o de carvalho. A estipe de amendoeira ora foi encaixada no grupo de videira, ora no grupo de pessegueiro ou não se encaixou em nenhum dos grupos.

Qin et al. (2001), através das técnicas de REP, ERIC e RAPD, descreveram três grupos, sendo o primeiro composto pelas estirpes de citros e de cafeeiro, o segundo com as de amendoeira, videira e ambrósia americana e o terceiro com as de olmo, carvalho e ameixeira. Os mesmos grupos também foram obtidos através da análise completa da região 16S rDNA (Chen et al., 2000).

Metha \& Rosato (2001), em um estudo de homologia de DNA, mostraram que as estirpes de citros, cafeeiro, videira e ameixeira pertencem a um mesmo grupo e que a estirpe de carvalho variou entre os grupos.

Wichman \& Hopkins (2002), analisando o perfil total de proteínas pelo método SDS-PAGE ("dodecyl sulfate polyacrylamide gel electrophoresis"), identificaram quatro grupos patogênicos das estirpes de X. fastidiosa: grupo de videira, grupo de sabugueiro (Sambucus nigra L.), grupo de carvalho e o grupo de oleandro.

Costa et al. (2000) observaram alta similaridade entre os isolados de citros e de cafeeiro $(0,87)$ e baixa similaridade em relação à estirpe de videira $(0,65)$; também observaram uma baixa similaridade entre os isolados da América do Sul e da América do Norte.

As análises entre diversos isolados da estirpe de citros resultaram em baixo nível de heterogeneidade (Coletta Filho \& Machado, 2002; Qin et al., 2001). Esses resultados são consistentes com os de Rosato et al. (1998), baseando-se em uma coleção de 
isolados semelhante. Entretanto, Coletta Filho et al. (2001) observaram uma maior diversidade genética entre isolados da estirpe de citros e comentaram que essa diferença pode ser devida aos isolados analisados serem de diferentes localidades geográficas, com pressões de seleção provavelmente distintas evidenciando-se assim uma relação entre a genética $X$. fastidiosa e a distribuição geográfica.

Li et al. (2002) relatam que as estirpes de citros, as quais infectam plantas de citros e de café (Li et al., 2001) e a estirpe de cafeeiro, as quais infectam plantas de café (Lima et al., 1998; Paradela Filho et al., 1995) são capazes de infectar, colonizar e produzir sintomas da doença de Pierce (PD) em videiras. Segundo Lopes et al. (2000), as estirpes de citros e de cafeeiro são distintas, pois apresentam diferentes mecanismos de patogenicidade em fumo e, possivelmente em citros e cafeeiro. Lopes et al. (2003) observaram que as estirpes de citros e de cafeeiro somente foram detectadas nas combinações homólogas, mas comenta que o reduzido número de plantas pode ter interferido.

Lopes et al. (2003) observaram similaridades entre as estirpes de citros e cafeeiro, quanto à capacidade de infecção e colonização de plantas invasoras após inoculação mecânica.

\subsection{Métodos de detecção e quantificação de $X$. fastidiosa}

Vários são os métodos utilizados na detecção de $X$. fastidiosa em plantas e em insetos. O isolamento em meio de cultura é tradicionalmente usado na detecção de bactérias fitopatogênicas, pois além da detecção, possibilita a recuperação das células viáveis e, portanto, a quantificação da população no interior da planta através da contagem das unidades formadoras de colônia (UFC). No entanto, a utilização deste método é dificultada pelo fato de $X$. fastidiosa apresentar crescimento lento em meio de cultura e exigir de meio rico em nutrientes (Pooler \& Hartung, 1995).

Métodos serológicos tais como "Western Blot", DIBA (Beretta et al., 1993; Paradela Filho et al., 1997) e ELISA (Leite Júnior \& Leite, 1991; Paradela Filho et al., 1997), que utilizam anticorpos policlonais, podem resultar em reações inespecíficas 
(Chang et al., 1993). O ELISA permite a avaliação de um grande número de amostras a um custo mediano, com um limiar de detecção de $10^{4} \mathrm{UFC} / \mathrm{mL}$ (Minsavage et al., 1994).

Os pesquisadores, de uma maneira geral, têm preferido desenvolver técnicas de detecção que permitam uma diagnose rápida e segura (Coletta Filho et al., 2001), como a técnica de PCR. Este método tem sido amplamente utilizado na detecção de X. fastidiosa nas plantas (Minsavage et al., 1994; Paradela Filho et al., 1997; Pooler \& Hartung, 1995), pois permite um diagnóstico relativamente rápido e seguro, com alta sensibilidade $\left(10^{2}\right.$ a $\left.10^{3} \mathrm{UFC} / \mathrm{mL}\right)$ (Minsavage et al., 1994).

\subsubsection{Isolamento e cultivo bacteriano em meio de cultura}

O método de isolamento em meio de cultura é importante, pois permite a quantificação das células viáveis da bactéria com alta confiabilidade, desde que a identidade das colônias obtidas seja confirmada por outros métodos envolvendo PCR ou serologia. Este método apresenta alguns problemas, tais como a demora na obtenção dos resultados (15 a 20 dias), menor sensibilidade quando comparado com o método de PCR e alto risco de contaminação, uma vez que os meios utilizados são ricos em nutrientes (Coletta Filho \& Machado, 2001).

Diversos meios são descritos para o isolamento bacteriano, dentre eles: PD2 ("Pirce's disease") (Davis et al., 1980), PW ("periwinkle wilt Agar") (Davis et al., 1981), PWH ("periwinkle wilt" suplementado com L-histidina) (Lee et al., 1993), SPW ("periwinkle wilt" suplementado) (Hartung et al., 1994) e PWG ("periwinkle wilt gelrite") (Hill \& Purcell, 1995b), que apresentam pequenas modificações tais como a quantidade de reagentes e a mudança de geleificantes. Já os meios BCYE ("buffered charcoal yeast extract") (Wells et al., 1981a) e CS-20 (Chang \& Walker, 1988) apresentam fontes alternativas de nutrientes. Os mais utilizados para o isolamento das várias estirpes de $X$. fastidiosa são o PD2, o BCYE, o PW, o PWS e o CS20 (Campanharo et al., 2003).

Hopkins (1985) desenvolveu um protocolo para estimar a população de células viáveis de $X$. fastidiosa em videira com a doença de Pierce (PD). Este protocolo foi 
baseado na contagem das unidades formadoras de colônia (UFC) em meio de cultura sólido, através de plaqueamentos sucessivos das diluições. Uma modificação desta técnica (Hill \& Purcell, 1995b) foi utilizada em hospedeiros alternativos, onde foram detectadas populações de $10^{9} \mathrm{UFC} / \mathrm{g}$ de tecido com uma sensibilidade teórica de $10^{3}$ UFC/g de tecido amostrado. A mesma técnica foi utilizada com sucesso para quantificar a população de $X$. fastidiosa em citros (Almeida et al., 2001).

O primeiro isolamento de $X$. fastidiosa de plantas de citros foi feito em meio BCYE (Leite Júnior \& Leite, 1991), e para o fechamento dos postulados de Koch usouse o meio PW (Chang et al., 1993), que proporcionou menor período de incubação que o observado no meio PWH (Lee et al., 1993). Posteriormente, desenvolveu-se o meio PWS, que mostrou ser mais eficiente que o PD2 (Hartung et al., 1994).

Uchibaba et al. (1992) notaram que os meios BCYE e PD3 proporcionaram maior desenvolvimento das colônias da estirpe de ameixeira, e que no meio BCYE ocorreu maior recuperação da população da bactéria.

Almeida et al. (2001) compararam os meios BCYE, PW e PWG e bservaram que os meios PW e PWG foram mais eficientes no isolamento da estirpe de citros de $X$. fastidiosa das plantas de citros, propiciando menor período de incubação e maiores tamanhos de colônia. Lacava (2000) também observou que o meio PW proporcionou menor período de incubação da bactéria, enquanto que o meio BCYE proporcionou maior massa bacteriana.

Para o isolamento da estirpe de cafeeiro de X. fastidiosa, já foram utilizados os meios PWS (Lima et al., 1996; Lima et al., 1998) e PWG (Marucci et al., 2003), mas não foram feitas comparações entre eles.

\subsubsection{Teste de "Polimerase Chain Reaction" (PCR)}

O teste de PCR provocou uma verdadeira revolução na biologia devido à sua facilidade, rapidez, versatilidade e sensibilidade. Segundo Coletta Filho (1999), havia a necessidade de uma técnica que detectasse o patógeno, no caso $X$. fastidiosa, em baixas 
concentrações, que apresentasse especificidade em relação ao patógeno e certa rapidez na sua execução.

Este teste possibilita a amplificação exponencial da seqüência de um DNA através de ciclos repetitivos de síntese de DNA. Cada ciclo de PCR consiste de três etapas: a) desnaturação térmica $\left(92\right.$ a $\left.95^{\circ} \mathrm{C}\right)$ da fita dupla do DNA; b) anelamento sob temperatura reduzida $\left(35\right.$ a $\left.60^{\circ} \mathrm{C}\right)$, que varia dependendo essencialmente do tamanho e seqüência do "primer" utilizado, permitindo a hibridização DNA-DNA de cada "primer" com as seqüências complementares que flanqueiam a região alvo; e c) extensão das novas fitas de DNA, produzidas através da elevação da temperatura $\left(72^{\circ} \mathrm{C}\right)$ e com a adição de enzima DNA polimerase e de nucleotídeos (Miller \& Joaquim, 1993). A visualização dos produtos de amplificação é feita sob luz ultravioleta, após eletroforese do DNA em géis de agarose adicionados de brometo de etídio, onde a sua interpretação depende dos propósitos pelos quais se utiliza a técnica.

A especificidade do teste deriva do desenvolvimento de sondas ("primers") de oligonucleotídeos que reconhecem sequiências específicas no DNA do patógeno, no caso, X. fastidiosa. Os "primers" desenvolvidos por Minsavage et al. (1994) não distinguem as estirpes de videira, de ameixeira e de citros e são conhecidos como RST31 e RST33, os quais amplificam um fragmento de 700 pares de base (pb). Os "primers" 272-1 e 272-2 externos não são específicos para $X$. fastidiosa, enquanto que o par o CVC-1 e 272-2-int são específicos à estirpe de citros, distinguindo-a da estirpe de videira, mas não da estirpe de cafeeiro, e, amplificam uma região no genoma da bactéria com comprimento próximo a 500 pb (Pooler \& Hartung, 1995).

Segundo Henson \& French (1993), o método de PCR é altamente sensível na detecção de $X$. fastidiosa, sendo o mais recomendado apesar de não permitir sua quantificação. A bactéria tem sido detectada em diversos hospedeiros pelo método de PCR, tais como em citros (Beretta et al., 1997), videira (Purcell \& Saunders, 1999) e cafeeiro (Lima et al., 1998) entre outros, com resultados precisos devido à alta sensibilidade do teste (Pooler \& Hartung, 1995).

Um dos empecilhos para este teste é a extração de DNA que pode, em alguns casos, liberar compostos que inibem as reações de polimerase em cadeia e, portanto, 
mascarar a presença da bactéria nas plantas ou mesmo nos insetos vetores (Pooler et al., 1997). Mas segundo Paião \& Leite Júnior (2001), a alta sensibilidade apresentada pela técnica faz com que a atuação dos inibidores seja mascarada.

Os insetos vetores, por apresentarem uma quantidade muito pequena de bactéria na cabeça exigem um método de detecção mais sensível, como é o caso do "nestedPCR". Neste tipo de PCR, primeiramente ocorre a amplificação do fragmento de DNA com um par de "primers" (externos) e, posteriormente o produto deste PCR serve como molde para uma segunda amplificação com um novo conjunto de "primers" internos à sequiência amplificada no primeiro PCR (Paião \& Leite Júnior, 2001). 


\section{MATERIAL E MÉTODOS}

O trabalho foi executado no Laboratório de Insetos Vetores (LIV) e casas de vegetação do Departamento de Entomologia, Fitopatologia e Zoologia Agrícola da Escola Superior de Agricultura "Luiz de Queiroz" (ESALQ) - Universidade de São Paulo, em Piracicaba. Contou com o apoio da Prof. Dra. Clarice Garcia Borges Demétrio e Adriano Ferreti Borgatto, do Departamento de Ciências Exatas da ESALQ/USP, e com a colaboração do Prof. Dr. Silvio Aparecido Lopes, da Universidade de Ribeirão Preto (UNAERP) e do pesquisador Luís Otávio Saggion Berian, do Instituto Biológico que forneceram isolados de citros e de cafeeiro de várias localidades.

\subsection{Obtenção e manutenção de plantas-teste}

Utilizaram-se mudas de café (Coffea arabica L.) obtidas a partir de sementes do cultivar Catuaí vermelho (clone 99) fornecidas pelo Instituto Agronômico de Campinas (IAC) e produzidas sob condições protegidas no campo experimental Dr. Alcides Carvalho, pertencente à Garcafé, em Garça, SP. As mudas de laranja doce (Citrus sinensis (L.) Osbeck), obtidas a partir de sementes da variedade Caipira, foram produzidas em viveiro telado pela Empresa Citrograf ${ }^{\circledR}$. Essas mudas, inicialmente em tubetes, foram transplantadas para sacos plásticos de $1 \mathrm{~L}$ contendo solo, esterco e areia na proporção 3:2:1. Um mês antes das inoculações, as plantas de citros foram podadas a $5 \mathrm{~cm}$ do solo e adubadas com farelado Heringer $^{\circledR}(\mathrm{NPK}+\mathrm{Ca}, \mathrm{S}, \mathrm{Mg}$ e $\mathrm{Zn})$ para a obtenção de brotações com crescimento uniforme. Após 2 meses das inoculações, as plantas foram transplantadas para sacos plásticos de $4 \mathrm{~L}$. As plantas foram conduzidas 
permanentemente em casa de vegetação protegida contra a entrada de cigarrinhas vetoras de $X$. fastidiosa.

Quando necessário, aplicou-se os inseticidas Vertimec (abamectina, Novartis, Brasiléia, Suíça) e Meotrin (fepropatrina Hokko, Osaka, Japão) para o controle do minador-dos-citros e do bicho mineiro (cafeeiro), respectivamente. Semanalmente, as plantas de café foram pulverizadas com uma calda contendo água + detergente $(10: 1)$, o que ajudou a conter a manifestação de bicho mineiro.

\subsection{Obtenção e preservação dos isolados de bactéria}

O isolado da estirpe de citros de Xylella fastidiosa foi obtido de plantas de laranja doce infectadas cedidas por W. Li (Estação Experimental de Citricultura de Bebedouro), que haviam sido inoculadas por enxertia, com tecido de laranjeira com CVC da região de Bebedouro/SP. O isolado da estirpe de cafeeiro foi obtido de plantas de café com sintomas de ARC, na Fazenda Cambuhy, Matão/SP. Estes dois isolados foram utilizados nos experimentos de inoculação. No estudo de caracterização morfológica, foram incluídos outros cinco isolados de cada estirpe, provenientes de laranjeiras com CVC (isolados 10, 18, 34, 35 e 37) e de cafeeiro com ARC (isolados 1, 17, 29, 32 e 33), representativos de várias regiões dos Estados de São Paulo e Minas Gerais (Figura 1).

Após o isolamento primário (item 3.3.1), todos os isolados foram purificados por tríplice clonagem, isto é, uma única colônia foi repicada por três vezes em meio de cultura sólido "periwinkle wilt gelrite" (PWG) (Hill \& Purcell, 1995b), sendo que na última todo o conteúdo de colônias da placa foi raspado com o auxílio de uma alça de platina e colocado em tampão fosfato salino ("phosphate buffer saline" - PBS) (10 mM $\mathrm{Na}_{2} \mathrm{HPO}_{4} ; 1,7 \mathrm{mM} \mathrm{KH} \mathrm{PO}_{4} ; 0,14 \mathrm{mM} \mathrm{NaCl} ; 2,7 \mathrm{mM} \mathrm{KCl} ; \mathrm{pH}$ 7,0) para a obtenção de uma suspensão bacteriana concentrada. Esta suspensão foi agitada com uma micropipeta e uma alíquota de $60 \mu \mathrm{L}$ foi adicionada a criotubos novos e autoclavados contendo 200 $\mu \mathrm{L}$ do tampão de preservação succinato citrato fosfato (SPC) $\left(8,6 \mathrm{mM} \mathrm{K}_{2} \mathrm{HPO}_{4} ; 7,3 \mathrm{mM}\right.$ $\mathrm{KH}_{2} \mathrm{PO}_{4} ; 7,3 \mathrm{mM}$ succinato dissódico; $3,4 \mathrm{mM}$ citrato dissódico; $\mathrm{pH}$ 7,0), acrescido de $30 \%$ de glicerol e também autoclavado. 
Municípios onde foram coletados os isolados de citros (CVC) de Xylella fastidiosa;

Municípios onde foram coletados os isolados de café (ARC) de Xylella fastidiosa;

Municípios onde foram coletados isolados de citros (CVC) e de café (ARC) de Xylella fastidiosa

\section{Comendador} Gomes

(35)

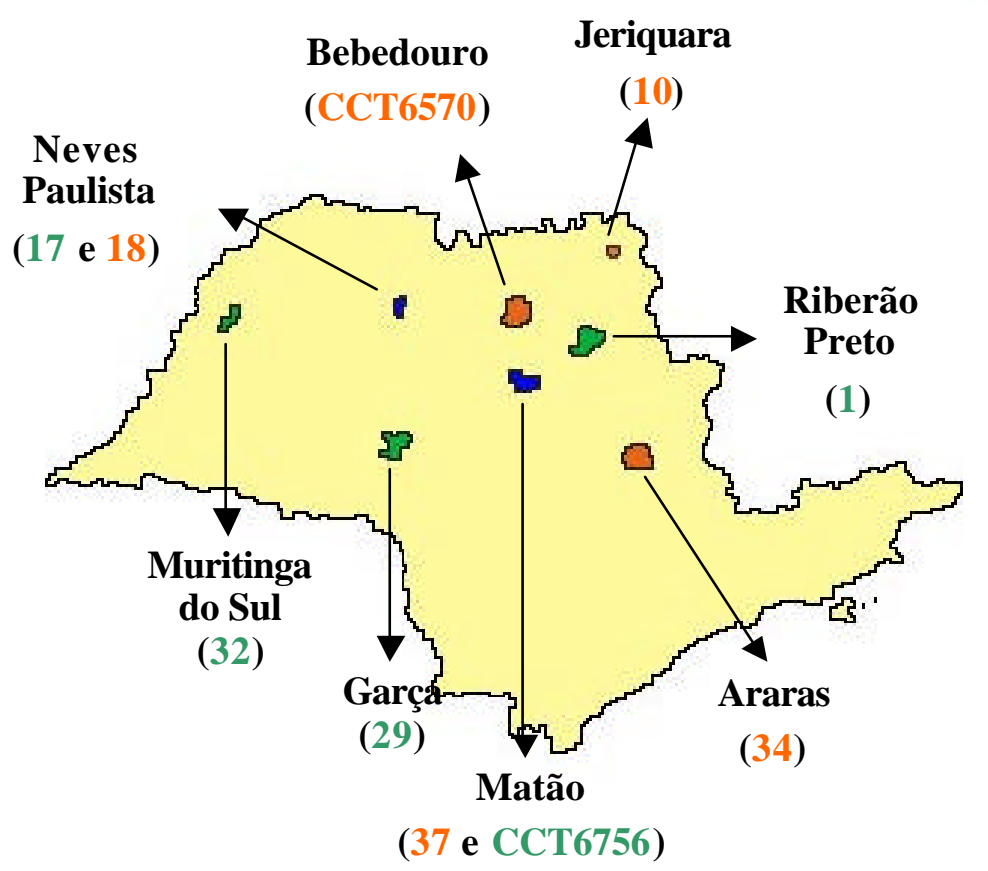

Lavras

(33)

Figura 1 - Localidades de origem dos isolados de Xylella fastidiosa de citros com CVC e de cafeeiro com ARC nos Estados de São Paulo e Minas Gerais. Os números entre parênteses representam o número do isolado e a cor representa os isolados de citros (laranja) e de cafeeiro (verde) 
Estes isolados encontram-se devidamente etiquetados e preservados em ultrafreezer $\left(-80^{\circ} \mathrm{C}\right)$ do Laboratório de Insetos Vetores da ESALQ. Os isolados CCT6570 e CCT6756 encontram-se também depositados na Coleção de Culturas Tropical da Fundação André Tosello (Campinas, SP). Antes da sua utilização nos experimentos, os isolados foram retirados do ultrafreezer e repicados duas vezes em meio de cultura sólido.

\subsection{Métodos de detecção e quantificação bacteriana utilizados nos experimentos}

\subsubsection{Isolamento primário e quantificação bacteriana em meio de cultura sólido}

Utilizourse o método de isolamento primário de X. fastidiosa em meio de cultura descrito por Hill \& Purcell (1995b), que foi adaptado por Almeida et al. (2001) para quantificar a população de X. fastidiosa em plantas de citros. Segundo Almeida et al. (2001), o limite de detecção desse método é de $10^{3} \mathrm{UFC} / \mathrm{g}$ de tecido vegetal.

O pecíolo e a nervura central de cada amostra foliar foram destacados, com o auxílio de uma lâmina cortante esterilizada, e pesados em balança semi-analítica (máximo de 0,10 g/amostra). Em câmara asséptica de fluxo laminar (modelo VLFS-09, Veco, Campinas, SP), utilizando-se somente materiais autoclavados $\left(120^{\circ} \mathrm{C} / 20 \mathrm{~min}\right)$, cada amostra passou por cinco banhos de imersão de $2 \mathrm{~min}$, em recipientes contendo álcool $(92,8 \%$ ) (uma vez), hipoclorito de sódio (2\%) (uma vez) e água destilada estéril (três vezes) para esterilização superficial. Após a desinfecção, ainda na câmara, as amostras foram cortadas em secções de 1-2 mm sobre papel filtro, com o auxílio de uma lâmina cortante esterilizada, e colocadas em tubos de ensaio contendo $2 \mathrm{~mL}$ de tampão PBS, previamente tampados e autoclavados. Nestes tubos de ensaio as amostras foram trituradas em homogeneizador tipo Turrax (modelo MA102, Marconi Equipamentos para Laboratório S.A., Piracicaba, SP) por 10 a 15 s, com uma rotação da haste giratória de, aproximadamente, $20.000 \mathrm{rpm}$. Entre uma trituração e outra, a haste era desinfetada por imersão em recipientes contendo água destilada autoclavada (5 s), álcool 92,8\% (15 s) e novamente água destilada autoclavada (5 s). A suspensão homogeneizada, foi 
diluída 10 vezes na câmara de fluxo laminar, através da transferência de $200 \mu \mathrm{L}$ de cada amostra para um mvo tubo de ensaio contendo $1,8 \mathrm{~mL}$ de tampão PBS autoclavado. Após a diluição, duas alíquotas de $20 \mu \mathrm{L}$ de cada amostra foram plaqueadas em meio de cultura sólido PWG. As placas foram acondicionadas em estufa à temperatura de $28^{\circ} \mathrm{C}$, sendo avaliadas sob microscópio estereoscópico aos 14 dias do plaqueamento, quanto ao número médio de unidades formadoras de colônia (UFC) nas duas alíquotas. As colônias de cada amostra foram submetidas ao teste de PCR com oligonucleotídeos específicos para X. fastidiosa (item 3.3.2), para confirmar a identidade da bactéria isolada.

A concentração bacteriana (C), medida em número de UFC por grama de tecido vegetal (UFC/g) foi calculada com base no peso inicial das amostras foliares e nas diluições do material vegetal em tampão PBS, utilizando-se a fórmula: $\mathrm{C}=$ 100.(1/p).UFC.(10 $)^{\mathrm{n}}$, onde n é o fator de diluição e p, o peso da amostra foliar (g).

\subsubsection{Teste de "Polymerase Chain Reaction" (PCR)}

A extração de DNA foi baseada no protocolo desenvolvido por Minsavage et al. (1994), adaptado para plantas de café por Pinto \& Leite (1999), através da otimização na concentração de ácido ascórbico para 0,1 M e diluição do extrato em 1:100.

Inicialmente, uma porção do pecíolo e nervura central das folhas de cada planta amostrada foi separada e, com o auxílio de uma lâmina, cortada em pedacinhos. As amostras foram maceradas com a ajuda de um pistilo em cadinho contendo $1 \mathrm{~mL}$ de tampão SPC, ácido ascórbico (0,1 M) e 5\% de polivinilpolipirrolidona insolúvel (PVPP Sigma P-6755) previamente lavada com ácido clorídrico (Holben et al., 1988). Após a maceração, $100 \mu \mathrm{L}$ do extrato da planta foi transferido para um tubo tipo "eppendorf" contendo $900 \mathrm{~mL}$ de água destilada e então centrifugado a $11.700 \mathrm{rpm}$ por um período de $2 \mathrm{~min}$, após o qual o sobrenadante foi descartado. O precipitado foi ressuspendido em $1 \mathrm{~mL}$ de água destilada e novamente centrifugado a $11.700 \mathrm{rpm}$ por $2 \mathrm{~min}$. Após o descarte do sobrenadante, o novo precipitado foi ressuspendido em uma solução contendo $567 \mu \mathrm{L}$ de TE $(10 \mathrm{mM}$ de Tris HCL; $1 \mathrm{mM}$ EDTA - ácido etileno diamono tetracético), $30 \mu \mathrm{L}$ de dodecil sulfato de sódio (SDS, Gibco BRL 15525-017) a 10\% e 3 
$\mu \mathrm{L}$ de proteinase $\mathrm{K}(20 \mathrm{mg} / \mathrm{mL})$ (Gibco BRL 25530-015), agitado em "vortex" e incubado a $37^{\circ} \mathrm{C}$ por 1 a $1,5 \mathrm{~h}$. A seguir, adicionou-se a cada amostra $100 \mu \mathrm{L}$ de $\mathrm{NaCl}(5$ M), agitou-se em "vortex", acrescentou-se $80 \mu \mathrm{L}$ de solução de CTAB/NaCl (0,27 M CTAB - brometo de cetiltrimetilamônio; 0,7 M NaCl) e mais uma vez agitou-se em "vortex", incubando-se por $10 \mathrm{~min}$ a $65^{\circ} \mathrm{C}$. Após esse período, as amostras permaneceram por $10 \mathrm{~min}$ em temperatura ambiente e posteriormente, adicionou-se 550 $\mu \mathrm{L}$ de clorofórmio:álcool isoamílico (24:1) em capela de exaustão, agitando-se manualmente por $10 \mathrm{~min}$ e centrifugando-se por $5 \mathrm{~min}$. Em capela, cerca de $700 \mu \mathrm{L}$ do sobrenadante obtido na centrifugação foi transferido para tubos novos contendo $420 \mu \mathrm{L}$ de álcool isopropílico gelado para a precipitação do DNA; os tubos foram invertidos lentamente e acondicionados em ultrafreezer $\left(-80^{\circ} \mathrm{C}\right)$. Passados $10 \mathrm{~min}$, as amostras foram retiradas do ultrafreezer e centrifugadas por $20 \mathrm{~min}$ a $11.700 \mathrm{rpm}$ em temperatura ambiente, sendo o sobrenadante removido cuidadosamente. Os precipitados secaram por cerca de $1,5 \mathrm{~h}$ e em seguida foram ressuspendidos em $50 \mu \mathrm{L}$ de TE, mantidos em temperatura ambiente por $1 \mathrm{~h}$ e estocados a $4^{\circ} \mathrm{C}$ para a realização do teste de PCR. O teste de PCR foi realizado com até 2 semanas após a extração de DNA das amostras. O uso do composto fenol:clorofórmio:álcool isoamílico foi eliminado do protocolo de extração de DNA após a observação preliminar de que o composto não influenciou a detecção bacteriana quando os testes foram realizados poucos dias após a extração de DNA.

Para a amplificação do DNA extraído de plantas, utilizaram-se os oligonucleotídeos ("primers") CVC-1 (AGATGAAAACAATCATGCAAA) e 272-2-int (GCCGCTTCGGAGAGCATTCCT) (Pooler \& Hartung, 1995), que amplificam um fragmento de $500 \mathrm{pb}$, e são específicos para X. fastidiosa de citros e de cafeeiro (Coletta Filho \& Machado, 2001). Segundo Pooler \& Hartung (1995), o teste de PCR permite a detecção de $10^{2}$ bactérias por reação de amplificação. Os oligonucleotídeos foram incluídos na seguinte mistura de reagentes: tampão $1 \mathrm{X}(75 \mathrm{mM}$ Tris- $\mathrm{HCl}(\mathrm{pH} 9,0), 2$ $\mathrm{mM} \mathrm{MgCh}, 50 \mathrm{mM} \mathrm{KCl}, 20 \mathrm{mM}\left(\mathrm{NH}_{4}\right)_{2} \mathrm{SO}_{4}$ - BIOTOOLS do Brasil); $200 \mu \mathrm{M}$ de cada dNTP (10 mM - BIOTOOLS do Brasil); $1 \mathrm{U}$ de Taq DNA polimerase (BIOTOOLS do 
Brasil); 0,4 $\mu \mathrm{M}$ de cada oligonucleotídeo (CVC-1 e 272-2-int) e de $2 \mu \mathrm{L}$ (colônia) a 3 $\mu \mathrm{L}$ (planta) de DNA da amostra, para um volume final de reação de $12 \mu \mathrm{L}$. Após a mistura estar pronta, adicionou-se a cada amostra $30 \mu \mathrm{L}$ de óleo mineral. A amplificação foi realizada em um termociclador PTC-100 (MJ Research Inc, Watertown, MA 02172, EUA), programado para as seguintes condições: 1 ciclo inicial a $94^{\circ} \mathrm{C}$ por 4 min.; 30 ciclos envolvendo desnaturação a $94^{\circ} \mathrm{C}$ por $1 \mathrm{~min}$, anelamento a $60^{\circ} \mathrm{C}$ por $1,5 \mathrm{~min} \mathrm{e}$ extensão a $72^{\circ} \mathrm{C}$ por $1,5 \mathrm{~min}$; e 1 ciclo final de extensão a $72^{\circ} \mathrm{C}$ por $10 \mathrm{~min}$, estabilizando a $4^{\circ} \mathrm{C}$ por tempo indeterminado (Pooler \& Hartung, 1995).

Após a amplificação, adicionourse $2 \mu \mathrm{L}$ de corante (azul de bromofenol 0,25\% e sacarose 40\%) por amostra e o produto da PCR foi visualizado através de eletroforese em gel de agarose (1,5\%), em tampão TBE (44,5 mM Tris, 44,5 mM ácido bórico e 1 mM EDTA, $\mathrm{pH} 8$,0) suplementado com $0,5 \mu \mathrm{g} / \mathrm{mL}$ de brometo de etídio. Os fragmentos amplificados foram visualizados sob luz UV e documentados em um fotodocumentador “Eagle Eye II" (Stratagene, La Jolla, CA 92037, EUA).

\subsection{Teste de inibição de crescimento de Xylella fastidiosa por homogeneizado de tecido cafeeiro}

O método de isolamento primário em meio de cultura (item 3.3.1) é eficiente na quantificação de X. fastidiosa (Hill \& Purcell, 1995b); entretanto, deve ser usado em casos onde o tecido vegetal não apresente efeito inibitório sobre o crescimento bacteriano, uma vez que esse método envolve a maceração dos tecidos, podendo interferir na interpretação dos resultados (Purcell \& Saunders, 1999). Assim, realizou-se este experimento para verificar se ocorre inibição de crescimento da estirpe de cafeeiro (isolado CCT6756) de $X$. fastidiosa por homogeneizado de tecido cafeeiro e também se o tipo de maceração pode afetar o crescimento da bactéria. Desta forma comparou-se: A) suspensão bacteriana macerada em cadinho na presença de tecido cafeeiro; B) suspensão bacteriana macerada em homogeneizador tipo Turrax (20.000 rpm por $15 \mathrm{~s}$ ) com tecido cafeeiro; C) somente a suspensão bacteriana não homogeneizada; D) suspensão 
bacteriana macerada em cadinho sem a presença de tecido vegetal; e E) suspensão bacteriana macerada em homogeneizador tipo Turrax sem a presença de tecido vegetal.

A partir do isolado CCT6756 preservado a $-80^{\circ} \mathrm{C}$ e repicado duas vezes em meio de cultura PWG (item 3.2), preparou-se uma suspensão com concentração de, aproximadamente, $10^{8} \mathrm{UFC} / \mathrm{mL}$ de PBS. Uma alíquota de $20 \mu \mathrm{L}$ desta suspensão bacteriana foi adicionada a tubos de ensaio ou cadinhos contendo $2 \mathrm{~mL}$ de PBS autoclavado, sendo a diluição resultante processada conforme os tratamentos descritos acima. Nos tratamentos A e B foram adicionados $0,1 \mathrm{~g}$ de nervura central e pecíolo de folhas de cafeeiro previamente esterilizado conforme descrito no item 3.3.1.

Após os tratamentos, as amostras foram diluídas $10^{-1}$ e $10^{-2}$ e plaqueadas em meio de cultura sólido PWG. A contagem de UFC foi realizada após 14 dias, obtendo-se uma média dos dois plaqueamentos (item 3.3.1).

O delineamento experimental foi inteiramente casualizado com cinco tratamentos e quatro repetições. Os dados foram transformados para $\log \mathrm{UFC} / \mathrm{g}$ de tecido e submetidos à análise de variância, sendo as médias comparadas pelo teste de Tukey $(a ́<0,05)$.

\subsection{Inoculação da estirpe de citros de $X$. fastidiosa em plantas de citros e de café}

Um primeiro experimento de inoculação da estirpe de citros de $X$. fastidiosa em plantas de citros e de café foi realizado em janeiro/2002 para confirmar a ocorrência de colonização de cafeeiro pela estirpe de citros ( $\mathrm{Li}$ et al., 2001), utilizando-se um isolado bacteriano distinto (CCT6570) e outro método de inoculação.

Preparou-se uma suspensão concentrada de $10^{9} \mathrm{UFC} / \mathrm{mL}$ de PBS do isolado CCT6570, após o mesmo ter sido tirado do ultrafreezer e repicado em meio de cultura por duas vezes (item 3.2). A bactéria foi inoculada mecanicamente por agulha nas plantas-teste conforme descrito por Hopkins (1985), depositando-se uma gota de $5 \mu \mathrm{L}$ de suspensão bacteriana sobre o caule e perfurando-se o local por cinco vezes com alfinete entomológico $\mathrm{n}^{\circ}$ 0. A inoculação foi realizada $1 \mathrm{~cm}$ abaixo do primeiro par de folhas totalmente distendido das plântulas de café e de citros, nas horas mais quentes do 
dia e após uma ondição de estresse hídrico da planta, para que as gotas da suspensão fossem absorvidas mais rapidamente (1-3 min). A concentração da suspensão bacteriana foi quantificada através do plaqueamento em meio de cultura PWG.

Foram inoculadas 45 plantas de citros e 45 plantas de café. A testemunha constou de 15 plantas de cada um dos hospedeiros, as quais foram inoculadas somente com PBS. A avaliação da sobrevivência e multiplicação bacteriana foi realizada 4 meses após a inoculação, determinando-se a proporção de plantas infectadas e a população bacteriana pelo método de isolamento em meio de cultura sólido (PWG) (item 3.3.1). Utilizou-se, também, o teste de PCR para a detecção de X. fastidiosa (item 3.3.2).

O delineamento estatístico utilizado foi inteiramente casualizado com dois tratamentos e três repetições, sendo 15 plantas por repetição. Os dados de proporção de plantas infectadas em cada hospedeiro foram comparados através do teste de diferença entre duas proporções (Magalhães \& Lima, 2002) e com os dados de quantificação bacteriana foram comparadas as populações de células viáveis do isolado nas duas plantas hospedeiras através da análise de variância, sendo as médias comparadas pelo teste de Tukey $(a ́<0,05)$.

\subsection{Inoculação cruzada de estirpes de citros e de cafeeiro de $X$. fastidiosa em plantas de citros e de café}

Realizoutse o experimento de inoculação cruzada das estirpes de citros e de cafeeiro de $X$. fastidiosa em plantas de citros e de café, envolvendo diferentes concentrações de inoculo, para se avaliar a sobrevivência e multiplicação das duas estirpes e determinar a dose efetiva para infecção em cada combinação estirpe/hospedeiro.

Inocularam-se quatro concentrações de inóculo das estirpes de citros e de cafeeiro de $X$ fastidiosa nas duas plantas hospedeiras, em dois experimentos distintos. No primeiro, inoculou-se o isolado de cafeeiro CCT6756 (fevereiro/2002) e no segundo, o isolado de citros CCT6570 (março/2002). Os dois isolados foram retirados do ultrafreezer e repicados em meio de cultura PWG por duas vezes (item 3.2). As colônias 
do segundo repique foram retiradas com alça de platina e homogeneizadas em PBS para o preparo de uma suspensão bacteriana concentrada $\left(10^{8}-10^{9} \mathrm{UFC} / \mathrm{mL}\right)$, que foi diluída em série para a obtenção das demais concentrações. Todas as suspensões resultantes foram plaqueadas em meio de cultura PWG para a quantificação bacteriana (item 3.3.1).

As concentrações do inóculo obtidas para a estirpe de citros foram 3,2 x $10^{8}$ $\mathrm{UFC} / \mathrm{mL}, 6,2 \times 10^{7} \mathrm{UFC} / \mathrm{mL}, 3,0 \times 10^{5} \mathrm{UFC} / \mathrm{mL}$ e $5,0 \times 10^{3} \mathrm{UFC} / \mathrm{mL}$. Já para a estirpe de cafeeiro, as concentrações do inóculo foram 3,0 x $10^{9} \mathrm{UFC} / \mathrm{mL}, 9,5 \times 10^{7} \mathrm{UFC} / \mathrm{mL}$, $7,5 \times 10^{6} \mathrm{UFC} / \mathrm{mL}$ e $1,5 \times 10^{4} \mathrm{UFC} / \mathrm{mL}$. As suspensões bacterianas foram inoculadas nas plantas conforme descrito no item 3.5.

Os dois experimentos foram montados segundo um esquema fatorial, com delineamento inteiramente casualizado, sendo um dos fatores a espécie hospedeira (cafeeiro e citros) e o outro, a concentração do inóculo, totalizando oito tratamentos (2 hospedeiros x 4 doses), com três repetições de 15 plantas. Assim, cada isolado foi inoculado em 180 plantas de citros e 180 de café, sendo que 20 plantas de cada hospedeiro foram inoculadas apenas com PBS (controle negativo). Os experimentos foram instalados em datas diferentes, por motivo operacional (tempo necessário para processamento das amostras nos testes de isolamento). As plantas foram etiquetadas e após a inoculação (Figura 2A), as parcelas foram dispostas na casa de vegetação, conforme sorteio realizado através do programa SAS 6.12 (Figura 2B).

Mensalmente, as plantas inoculadas foram avaliadas quanto ao aparecimento de sintomas de CVC e de ARC. Com 2, 8, 16 e 32 semanas após a inoculação, foram realizadas as avaliações de sobrevivência e multiplicação bacteriana, determinando-se a proporção de plantas infectadas e a população bacteriana pelo método de isolamento em meio de cultura (item 3.3.1). Para confirmar a detecção de X. fastidiosa, utilizoutse o teste de PCR (item 3.3.2). 


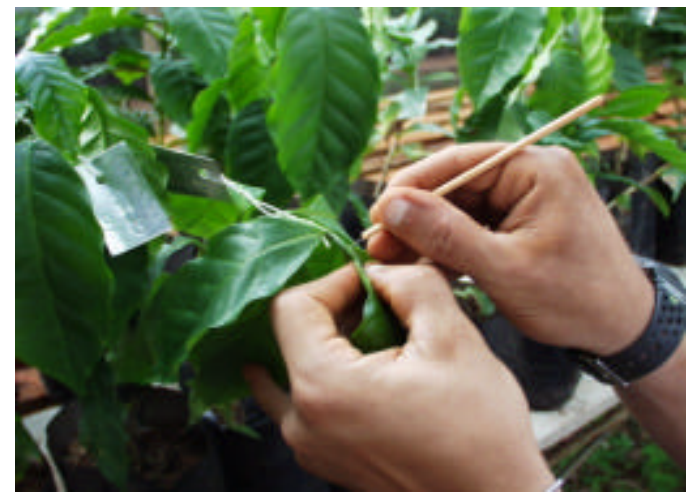

A

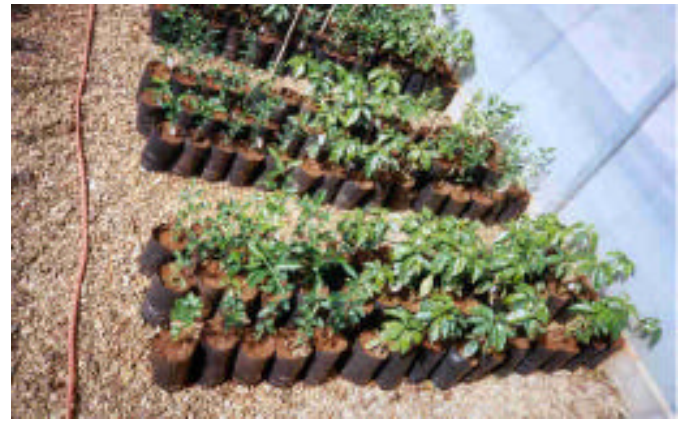

B

Figura 2 - Inoculação da bactéria Xylella fastidiosa em planta de café (A), arranjo das plantas na casa de vegetação seguindo o sorteio realizado pelo SAS (B)

Para a estimativa de dose efetiva, utilizourse o programa Maple 7.00 e para a elaboração da curva de titulação, pelos dados serem de proporção de plantas, utilizou-se uma regressão binomial do tipo logística que são exemplos de modelos lineares generalizados (Nelder \& Wedderburn, 1972).

O modelo de regressão logístico foi usado para o logarítmo das concentrações do inóculo bacteriano, observando-se que em alguns casos a "deviance" residual (generalização da soma de quadrados para a análise de variância) não é próxima ao número de graus de liberdade, evidenciando problemas de dispersão dos dados sendo que em alguns casos ocorreu variação dos dados maior do que o esperado no modelo binomial (superdispersão) e em outros casos esta variação foi menor do que esperado no modelo binomial (subdispersão). Nestes casos, considerou-se no modelo um fator de heterogeneidade $(\phi)$. Para os ajustes dos dados, foram realizadas regressões lineares, quando estas foram significativas realizaram-se regressões quadráticas e, as quadráticas quando significativas realizaram-se regressões cúbicas.

A partir da quantificação bacteriana, compararam-se as populações de células viáveis das estirpes de CVC e de ARC nas plantas através da análise de variância, sendo as médias comparadas pelo teste de Tukey $(a ́<0,05)$. 


\subsection{Variações em morfologia e crescimento de colônias em meio de cultura entre estirpes de $X$. fastidiosa de citros e de cafeeiro}

Isolados de $X$. fastidiosa de citros e de cafeeiro foram comparados quanto à morfologia e crescimento de colônias em meio de cultura sólido PWG. Seis isolados de $X$. fastidiosa de cada hospedeiro foram coletados em diferentes regiões geográficas e purificados conforme descrito no item 3.2. Para a instalação dos experimentos, foram preparadas suspensões concentradas dos isolados, e realizadas diluições seriais de $10^{-1}$, $10^{-2}, 10^{-3}, 10^{-4}, 10^{-5}$ e $10^{-6}$, e somente plaqueadas as diluições $10^{-5}$ e $10^{-6}$, sendo quatro alíquotas por placa em quatro placas para cada isolado.

No primeiro experimento foram avaliados três isolados de citros com CVC (CCT6570, 18 e 37) e três isolados de cafeeiro com sintomas de ARC (CCT6756, 32 e 33), quanto ao período de incubação a $28^{\circ} \mathrm{C}$, diâmetro de colônias 15 dias após o plaqueamento, aspecto morfológico das colônias sob microscópio ótico e mudanças na coloração do meio.

Diariamente, todas as placas foram observadas quanto ao aparecimento de UFC para a determinação do período de incubação de cada isolado.

No segundo experimento, repetiram-se os seis isolados anteriores e foram acrescentados mais seis isolados, sendo três da estirpe de citros (10, 34 e 35) e três da estirpe de cafeeiro (1, 17 e 29). Analisaram-se os mesmos parâmetros já descritos.

$\mathrm{O}$ diâmetro médio das colônias aos 15 dias após a instalação dos experimentos foi avaliado estatisticamente, medindo-se o diâmetro de 10 colônias tomadas ao acaso por alíquota, em 8 alíquotas, totalizando 80 colônias/isolado. A medição foi realizada com o auxílio de uma ocular micrométrica Wild (modelo MM 5235; Heerbrugg, Suíça) acoplada a um microscópio estereoscópico. Os dados de diâmetro de colônias foram submetidos à análise de variância, sendo as médias comparadas pelo teste de Tukey $(a ́<0,05)$.

Em microscópio ótico (modelo AXIOLAB, ZEISS) com aumentos de 40 e 100 vezes, observou-se a morfologia externa das colônias, que foram fotodocumentadas pelo programa “KS300 3.0” (ZEISS). 


\section{RESULTADOS E DISCUSSÃO}

\subsection{Teste de inibição de crescimento de Xylella fastidiosa por homogeneizado de tecido cafeeiro}

A população bacteriana recuperada em meio de cultura sólido PWG após homogeneização de tecido cafeeiro com suspensão de X. fastidiosa em cadinho ou triturador tipo Turrax foi maior $(\mathrm{F}=7,21 ; \mathrm{P}=0,002)$ que as obtidas de suspensões homogeneizadas sem adição de tecido da planta (Tabela 1). Quanto aos dois tipos de homogeneização utilizados, cadinho e Turrax, não houve diferença estatística na recuperação das células viáveis tanto na presença quanto na ausência de tecido cafeeiro.

Este experimento mostra que o tecido de cafeeiro, quando macerado com uma suspensão da estirpe de cafeeiro de X. fastidiosa, não inibe o crescimento bacteriano, mas ao contrário, parece favorecê-lo. Este resultado indica que o método de isolamento envolvendo homogeneização de tecido vegetal infectado e subseqüente plaqueamento em PWG sólido (Hill \& Purcell, 1995b), é adequado para o isolamento primário de $X$. fastidiosa de cafeeiro e quantificação bacteriana.

Em estudo semelhante, Purcell \& Sanders (1999) relataram que a homogeneização de suspensões de $X$. fastidiosa com tecido vegetal de certas plantas, tais como, nogueira (Junglans hindsii) e cafeeiro (Rhamnus californica), liberou inibidores de crescimento da bactéria. No entanto, Hartung et al. (1994) e Almeida et al. (2001) observaram que a presença de macerado de tecido cítrico estimulou o crescimento de estirpes de citros de X. fastidiosa em meios de cultura. Marucci et al. (2003) não observaram efeito inibitório de tecido de plantas de boldo (Vernonia condensata Baker) 
e de lixeira [Aloysia virgata (Ruiz \& Pavan)], que são hospedeiras de cigarrinhas, sobre o crescimento in vitro de uma estirpe de citros de X. fastidiosa.

Tabela 1. Crescimento da estirpe de cafeeiro de Xylella fastidiosa em meio de cultura sólido, 14 dias após homogeneização com ou sem tecido cafeeiro

Tratamentos (métodos de homogeneização)

População bacteriana

$\log \mathrm{UFC} / \mathrm{g} \pm \mathrm{EPM}^{2}$

S.B. ${ }^{1}+$ pecíolo + nervura central (cadinho)

$6,02 \pm 0,04 a^{3}$

S.B. + pecíolo + nervura central (Turrax)

$5,81 \pm 0,15 \mathrm{ab}$

Apenas S.B. (não homogeneizado)

$5,19 \pm 0,17$ bc

Apenas S.B. (cadinho)

$5,02 \pm 0,24$ c

Apenas S.B. (Turrax)

$4,72 \pm 0,22$ c

\footnotetext{
T'Suspensão bacteriana (isolado CCT6756) com concentração de $10^{9}$ UFC/mL em tampão fosfato salino;

${ }^{2}$ Erro padrão da média;

${ }^{3}$ Médias seguidas de mesma letra não diferem estatisticamente pelo teste de Tukey $(\alpha<$ $0,05)$.
}

\subsection{Inoculação da estirpe de citros de $X$. fastidiosa em plantas de citros e de café}

Aos 4 meses após a inoculação da estirpe de citros (CVC) em plantas de citros (combinação homóloga) e de café (combinação heteróloga), a porcentagem de plantas de citros infectadas foi estatisticamente maior que as de café, tanto pelo teste de isolamento em meio de cultura $(Z=4,87 ; P=0,01)$ quanto pelo teste de PCR $(Z=3,19 ; P=0,01)$ (Figura 3). 


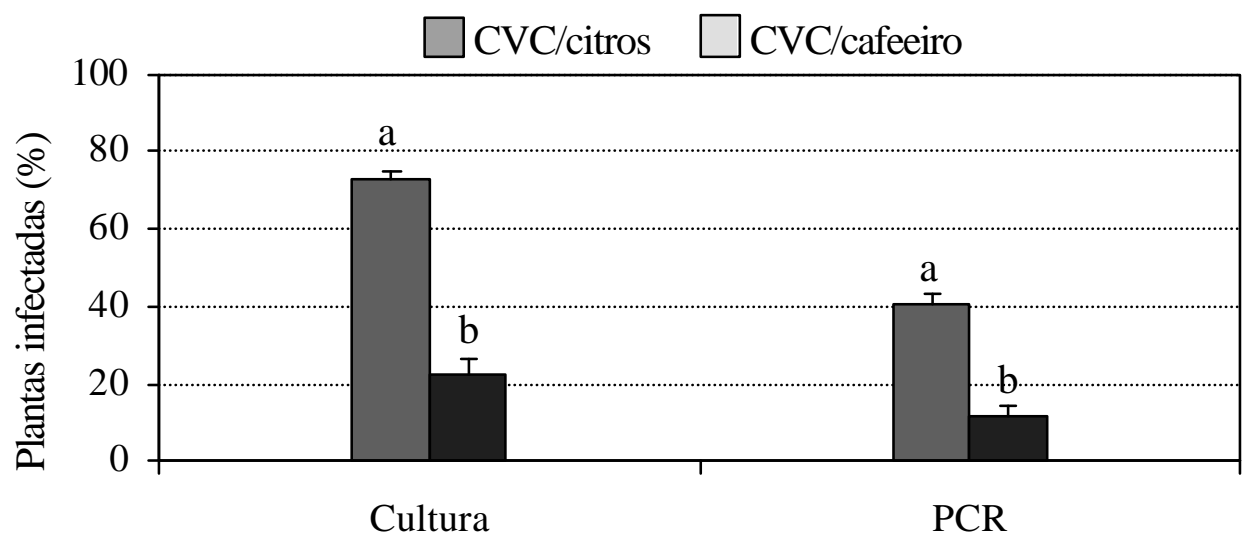

Método de detecção

Figura 3 - Porcentagem de plantas de citros e de café positivas para Xylella fastidiosa por cultura e PCR, 4 meses após a inoculação com agulha de uma suspensão de células $\left(10^{9} \mathrm{UFC} / \mathrm{mL}\right)$ da estirpe de citros (CVC; isolado CCT6570). Médias com letras diferentes diferem entre si pelo teste de Tukey $(\alpha=0,05)$

Além dos dados de porcentagem de plantas infectadas, o método de isolamento em meio de cultura permitiu a quantificação da população bacteriana no interior da planta com eficiência assegurada para as duas plantas, já que tecidos de plantas cítricas e de cafeeiro não inibem o crescimento de $X$. fastidiosa.

A população bacteriana na combinação homóloga foi 8,6 vezes maior $(Z=4,87$; $\mathrm{P}=0,01$ ) que na heteróloga (Tabela 2). Estes resultados confirmam que a estirpe de citros de X. fastidiosa também infecta plantas de café (Li et al., 2001), porém, com menor eficiência. A menor incidência de infecção e população bacteriana na combinação heteróloga se devem, provavelmente, a uma menor afinidade da estirpe de citros com a planta de café, mostrando que há multiplicação diferencial de $X$. fastidiosa entre diferentes hospedeiros, conforme relatado por Fry \& Milholland (1990). 
Tabela 2. Isolamento e quantificação populacional de Xylella fastidiosa em citros e cafeeiro, 4 meses após a inoculação de uma suspensão de células $\left(10^{9}\right.$ $\mathrm{UFC} / \mathrm{mL}$ ) da estirpe de citros (CVC; isolado CCT6570)

\begin{tabular}{cc}
\hline $\begin{array}{c}\text { Combinação } \\
\text { estirpe/planta }\end{array}$ & $\begin{array}{c}\text { População bacteriana } \\
\left(\log \text { UFC/g de tecido } \pm \mathrm{EPM}^{1}\right)\end{array}$ \\
\hline CVC/citros & $6,25 \pm 0,1 \mathrm{a}^{2}$ \\
CVC/cafeeiro & $5,32 \pm 0,2 \mathrm{~b}$ \\
${ }^{1}$ Erro padrão da média; & \\
${ }^{2}$ Médias seguidas de mesma letra não diferem estatisticamente pelo teste de Tukey \\
$(\alpha<0,05)$.
\end{tabular}

\subsection{Inoculação cruzada de estirpes de citros e de cafeeiro de $X$. fastidiosa em plantas de citros e de café}

$\mathrm{Na}$ avaliação de 2 semanas após a inoculação, não foi detectada nenhuma das duas estirpes de $X$. fastidiosa nas plantas de citros e de café. Estes resultados diferiram do obtido por Almeida et al. (2001), que isolaram a estirpe de citros (isolado CCT6570) das plantas de citros com apenas 1 semana após a inoculação.

Das quatro concentrações de inóculo utilizadas para a estirpe de cafeeiro (ARC), as três maiores $\left(10^{9}, 10^{7}\right.$ e $\left.10^{6} \mathrm{UFC} / \mathrm{mL}\right)$ resultaram em infecções que puderam ser detectadas por cultura e PCR na combinação ARC/cafeeiro, a partir de 2 meses da inoculação (Tabela 3). No caso das inoculações com a estirpe de citros (CVC), apenas as duas maiores concentrações $\left(10^{8}\right.$ e $\left.10^{7} \mathrm{UFC} / \mathrm{mL}\right)$ produziram infecções detectáveis em citros e cafeeiro (Tabelas 4 e 5). Os sintomas típicos de CVC somente foram observados nas plantas cítricas inoculadas com a estirpe de citros nas duas maiores concentrações, $10^{8}$ e $10^{7} \mathrm{UFC} / \mathrm{mL}$, nas taxas médias de 40 e $4,4 \%$ das plantas, respectivamente. Para as inoculações da estirpe de cafeeiro em citros (combinação heteróloga), não foi possível detectar a bactéria em nenhum dos tratamentos por cultura e por PCR, possivelmente pelo não estabelecimento (ou baixa sobrevivência) de infecções primárias desta estirpe na planta cítrica. 
Tabela 3. Porcentagem de plantas de café positivas para Xylella fastidiosa por cultura ou PCR, após períodos sucessivos de38 inoculação por agulha de diferentes concentrações de células da estirpe de cafeeiro (ARC; isolado CCT6756)

\begin{tabular}{ccccccccccc}
\hline $\begin{array}{l}\text { Concentração } \\
\text { do inóculo } \\
\text { (UFC/mL) }\end{array}$ & Repetição & \multicolumn{2}{c}{2 meses } & \multicolumn{2}{c}{4 meses } & \multicolumn{2}{c}{8 meses } & \multicolumn{3}{c}{ cumulativa (8 meses) } \\
\cline { 3 - 11 } & Cultura & PCR & Cultura & PCR & Cultura & PCR & Cultura & PCR & $\begin{array}{c}\text { Cultura }+ \\
\text { PCR }\end{array}$ \\
\hline \multirow{2}{*}{$10^{9}$} & I & 20,0 & 20,0 & 30,8 & 0,0 & 28,6 & 13,3 & 53,3 & 33,3 & 60,0 \\
& II & 20,0 & 33,3 & 60,0 & 46,7 & 50,0 & 57,1 & 66,6 & 73,3 & 86,6 \\
& III & 26,6 & 26,6 & 86,7 & 60,0 & 25,0 & 6,6 & 93,3 & 66,6 & 100,0 \\
\hline \multirow{2}{*}{$10^{7}$} & I & 13,3 & 20,0 & 42,9 & 13,3 & 13,3 & 14,3 & 46,6 & 20,0 & 53,3 \\
& II & 13,3 & 40,0 & 53,8 & 23,1 & 50,0 & 40,0 & 64,3 & 64,3 & 71,5 \\
& III & 20,0 & 26,6 & 45,5 & 26,7 & 30,8 & 33,3 & 53,3 & 53,3 & 53,3 \\
\hline \multirow{2}{*}{$10^{6}$} & I & 6,6 & 0,0 & 9,1 & 0,0 & 0,0 & 0,0 & 6,6 & 0,0 & 6,6 \\
& II & 20,0 & 13,3 & 23,1 & 13,3 & 46,2 & 40,0 & 40,0 & 40,0 & 46,6 \\
& III & 0,0 & 6,6 & 15,4 & 6,6 & 0,0 & 0,0 & 13,3 & 6,6 & 13,3 \\
\hline \multirow{2}{*}{$10^{4}$} & I & 0,0 & 0,0 & 0,0 & 0,0 & 0,0 & 0,0 & 0,0 & 0,0 & 0,0 \\
& II & 0,0 & 0,0 & 0,0 & 0,0 & 0,0 & 0,0 & 0,0 & 0,0 & 0,0 \\
& III & 0,0 & 0,0 & 0,0 & 0,0 & 0,0 & 0,0 & 0,0 & 0,0 & 0,0 \\
\hline
\end{tabular}


Tabela 4. Porcentagem de plantas de citros positivas para Xylella fastidiosa por cultura ou PCR, após períodos sucessivos de39 inoculação por agulha de diferentes concentrações de células da estirpe de citros (CVC; isolado CCT6570)

\begin{tabular}{ccccccccccc}
\hline $\begin{array}{l}\text { Concentração } \\
\text { do inóculo } \\
(\text { UFC/mL) }\end{array}$ & Repetição & \multicolumn{2}{c}{2 meses } & \multicolumn{2}{c}{4 meses } & \multicolumn{2}{c}{8 meses } & \multicolumn{3}{c}{ cumulativa (8 meses) } \\
\cline { 3 - 11 } & Cultura & PCR & Cultura & PCR & Cultura & PCR & Cultura & PCR & $\begin{array}{c}\text { Cultura }+ \\
\text { PCR }\end{array}$ \\
\hline \multirow{2}{*}{$10^{8}$} & I & 53,3 & 6,6 & 73,3 & 80,0 & 46,6 & 26,6 & 80,0 & 80,0 & 93,3 \\
& II & 33,3 & 13,3 & 53,3 & 73,3 & 46,2 & 40,0 & 86,6 & 80,0 & 86,6 \\
& III & 66,6 & 20,0 & 50,0 & 53,3 & 53,3 & 28,6 & 93,3 & 73,3 & 93,3 \\
\hline \multirow{2}{*}{$10^{7}$} & I & 30,8 & 13,3 & 16,6 & 40,0 & 7,1 & 20,0 & 40,0 & 53,3 & 60,0 \\
& II & 26,6 & 13,3 & 0,0 & 46,6 & 20,0 & 26,6 & 40,0 & 60,0 & 60,0 \\
& III & 21,4 & 13,3 & 6,6 & 33,3 & 6,6 & 0,0 & 26,6 & 40,0 & 40,0 \\
\hline \multirow{2}{*}{$10^{5}$} & I & 0,0 & 0,0 & 0,0 & 0,0 & 0,0 & 0,0 & 0,0 & 0,0 & 0,0 \\
& II & 0,0 & 0,0 & 0,0 & 0,0 & 0,0 & 0,0 & 0,0 & 0,0 & 0,0 \\
\hline \multirow{2}{*}{$10^{3}$} & III & 0,0 & 0,0 & 0,0 & 0,0 & 0,0 & 0,0 & 0,0 & 0,0 & 0,0 \\
& I & 0,0 & 0,0 & 0,0 & 0,0 & 0,0 & 0,0 & 0,0 & 0,0 & 0,0 \\
& II & 0,0 & 0,0 & 0,0 & 0,0 & 0,0 & 0,0 & 0,0 & 0,0 & 0,0 \\
\hline
\end{tabular}


Tabela 5. Porcentagem de plantas de café positivas para Xylella fastidiosa por cultura ou PCR, após períodos sucessivos de40 inoculação por agulha de diferentes concentrações de células da estirpe de citros (CVC; isolado CCT6570)

\begin{tabular}{|c|c|c|c|c|c|c|c|c|c|c|}
\hline \multirow{2}{*}{$\begin{array}{l}\text { Concentração } \\
\text { do inóculo } \\
\text { (UFC/mL) }\end{array}$} & \multirow[b]{2}{*}{ Repetição } & \multicolumn{2}{|c|}{2 meses } & \multicolumn{2}{|c|}{4 meses } & \multicolumn{2}{|c|}{8 meses } & \multicolumn{3}{|c|}{$\%$ cumulativa ( 8 meses) } \\
\hline & & Cultura & PCR & Cultura & PCR & Cultura & PCR & Cultura & PCR & $\begin{array}{c}\text { Cultura }+ \\
\text { PCR }\end{array}$ \\
\hline \multirow{3}{*}{$10^{8}$} & $\mathrm{I}$ & 23,1 & 0,0 & 6,6 & 0,0 & 6,6 & 0,0 & 20,0 & 0,0 & 20,0 \\
\hline & II & 45,5 & 0,0 & 6,6 & 6,6 & 0,0 & 0,0 & 33,3 & 6,6 & 33,3 \\
\hline & III & 0,0 & 0,0 & 13,3 & 6,6 & 21,4 & 0,0 & 33,3 & 6,6 & 33,3 \\
\hline \multirow{3}{*}{$10^{7}$} & I & 0,0 & 0,0 & 0,0 & 0,0 & 0,0 & 0,0 & 0,0 & 0,0 & 0,0 \\
\hline & II & 0,0 & 0,0 & 0,0 & 0,0 & 0,0 & 0,0 & 0,0 & 0,0 & 0,0 \\
\hline & III & 11,1 & 0,0 & 0,0 & 0,0 & 0,0 & 0,0 & 11,1 & 0,0 & 11,1 \\
\hline \multirow{3}{*}{$10^{5}$} & $\mathrm{I}$ & 0,0 & 0,0 & 0,0 & 0,0 & 0,0 & 0,0 & 0,0 & 0,0 & 0,0 \\
\hline & II & 0,0 & 0,0 & 0,0 & 0,0 & 0,0 & 0,0 & 0,0 & 0,0 & 0,0 \\
\hline & III & 0,0 & 0,0 & 0,0 & 0,0 & 0,0 & 0,0 & 0,0 & 0,0 & 0,0 \\
\hline \multirow{3}{*}{$10^{3}$} & I & 0,0 & 0,0 & 0,0 & 0,0 & 0,0 & 0,0 & 0,0 & 0,0 & 0,0 \\
\hline & II & 0,0 & 0,0 & 0,0 & 0,0 & 0,0 & 0,0 & 0,0 & 0,0 & 0,0 \\
\hline & III & 0,0 & 0,0 & 0,0 & 0,0 & 0,0 & 0,0 & 0,0 & 0,0 & 0,0 \\
\hline
\end{tabular}


A maior concentração de inóculo foi a que resultou em maior porcentagem de plantas infectadas em todas as combinações estirpe/hospedeiro (Tabelas 35). Para esta maior concentração, as avaliações por cultura e PCR foram realizadas também aos 12 meses após a inoculação. Os dados de porcentagem cumulativa de plantas positivas para $X$. fastidiosa por cultura ou PCR nas três combinações, ARC/cafeeiro, CVC/citros e $\mathrm{CVC} /$ cafeeiro mostram que a incidência de infecção aumentou até aos 8 meses, estabilizando-se aos 12 meses (Figura 4).

As porcentagens médias de plantas infectadas nas combinações ARC/cafeeiro e CVC/citros foram, em geral, maiores aos 4 meses após a inoculação (Figuras 5 e 6). Na combinação ARC/cafeeiro houve uma oscilação maior nos dados obtidos por cultura, isto é, aos 2 meses foi detectado um reduzido número de plantas infectadas, que aumentou drasticamente aos 4 meses, e depois declinou aos 8 meses (exceto para a menor concentração, de $10^{6} \mathrm{UFC} / \mathrm{mL}$ ) (Figura $5 \mathrm{~A}$ ). Já na combinação CVC/citros, a porcentagem de plantas positivas por cultura cresceu mais rapidamente, atingindo $50 \%$ aos 2 meses, aumentando aos 4 meses e reduzindo um pouco aos 8 meses (Figura 6A). Por PCR, no entanto, observourse aumento significativo em incidência de infecção na combinação CVC/citros apenas aos 4 meses (Figura 6B).

A combinação heteróloga $\mathrm{CVC} /$ cafeeiro, na maior concentração inoculada $\left(10^{8}\right.$ UFC/mL), resultou em uma incidência de infecção semelhante à obtida por cultura na combinação ARC/cafeeiro (22-23\%), aos 2 meses (Figuras 5 e 7). Aos 4 meses, no entanto, observouse um declínio na porcentagem de plantas infectadas (Figura 7A), chegando a zero, 12 meses após a inoculação (Figura 8).

A comparação das combinações $\mathrm{CVC} /$ citros e $\mathrm{CVC} /$ cafeeiro na maior concentração de inóculo $\left(10^{8} \mathrm{UFC} / \mathrm{mL}\right)$, realizada pelo teste de diferença entre duas proporções (Magalhães \& Lima, 2002), mostrou que a porcentagem de plantas infectadas na combinação homóloga foi maior do que na heteróloga aos $2(\mathrm{Z}=2,69 ; \mathrm{P}=$ 0,01), $4(Z=5,01 ; P=0,01)$ e 8 meses $(Z=4,00 ; P=0,01)$ após a inoculação (Figura 8). O teste de PCR só detectou a bactéria na combinação heteróloga aos 4 meses e a incidência de infecção foi muito menor do que na combinação homóloga $(Z=6,45 ; P=$ 0,01) (Figura 8B). 

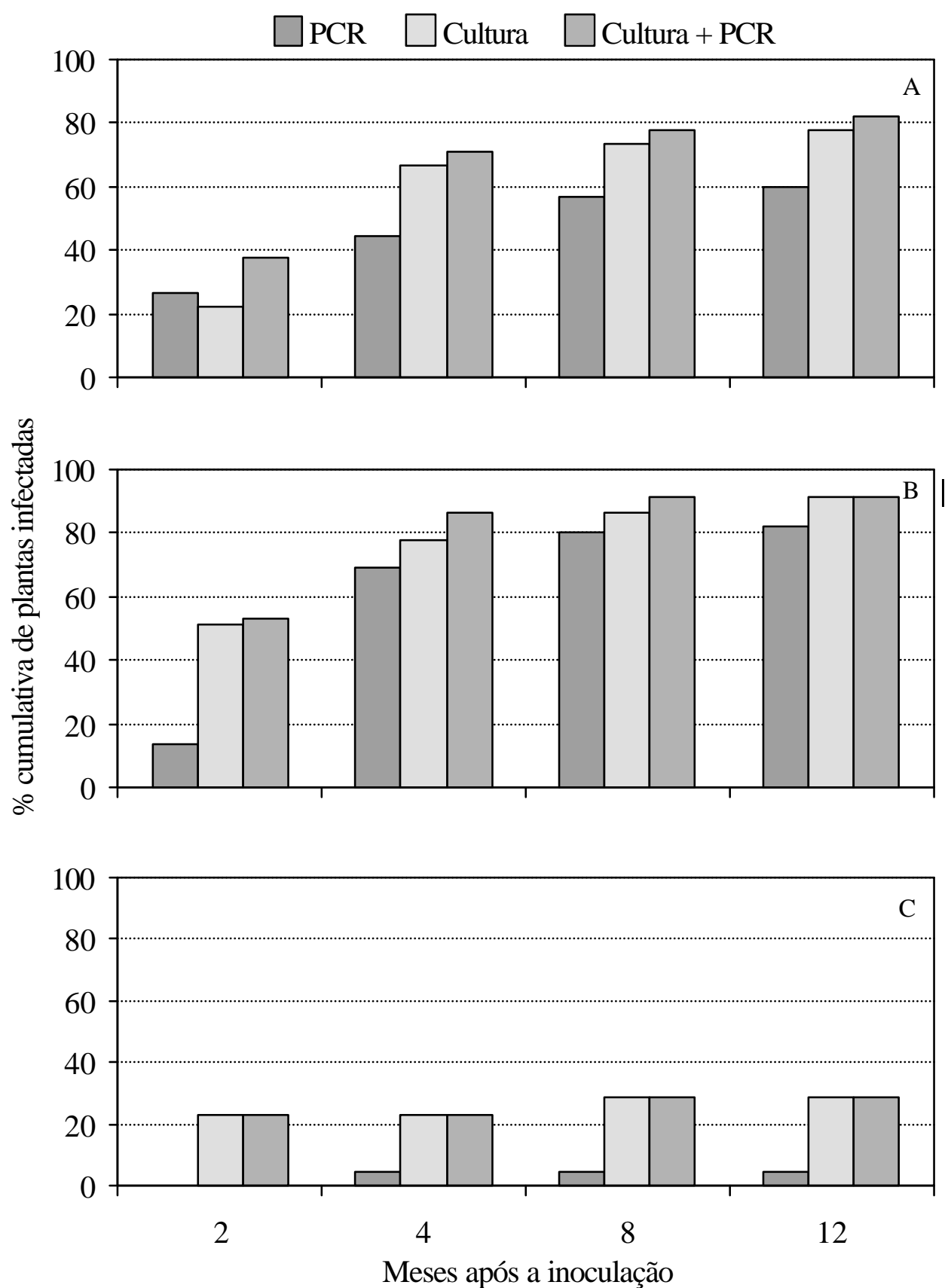

Figura 4 - Incidência cumulativa de plantas positivas para Xylella fastidiosa por PCR ou cultura, após a inoculação por agulha de suspensão de células das estirpes de citros (CVC $-10^{8} \mathrm{UFC} / \mathrm{mL}$ ) e de cafeeiro (ARC $-10^{9} \mathrm{UFC} / \mathrm{mL}$ ) nas seguintes combinações estirpe/hospedeiro: ARC/cafeeiro (A), CVC/citros (B) e CVC/cafeeiro (C) 


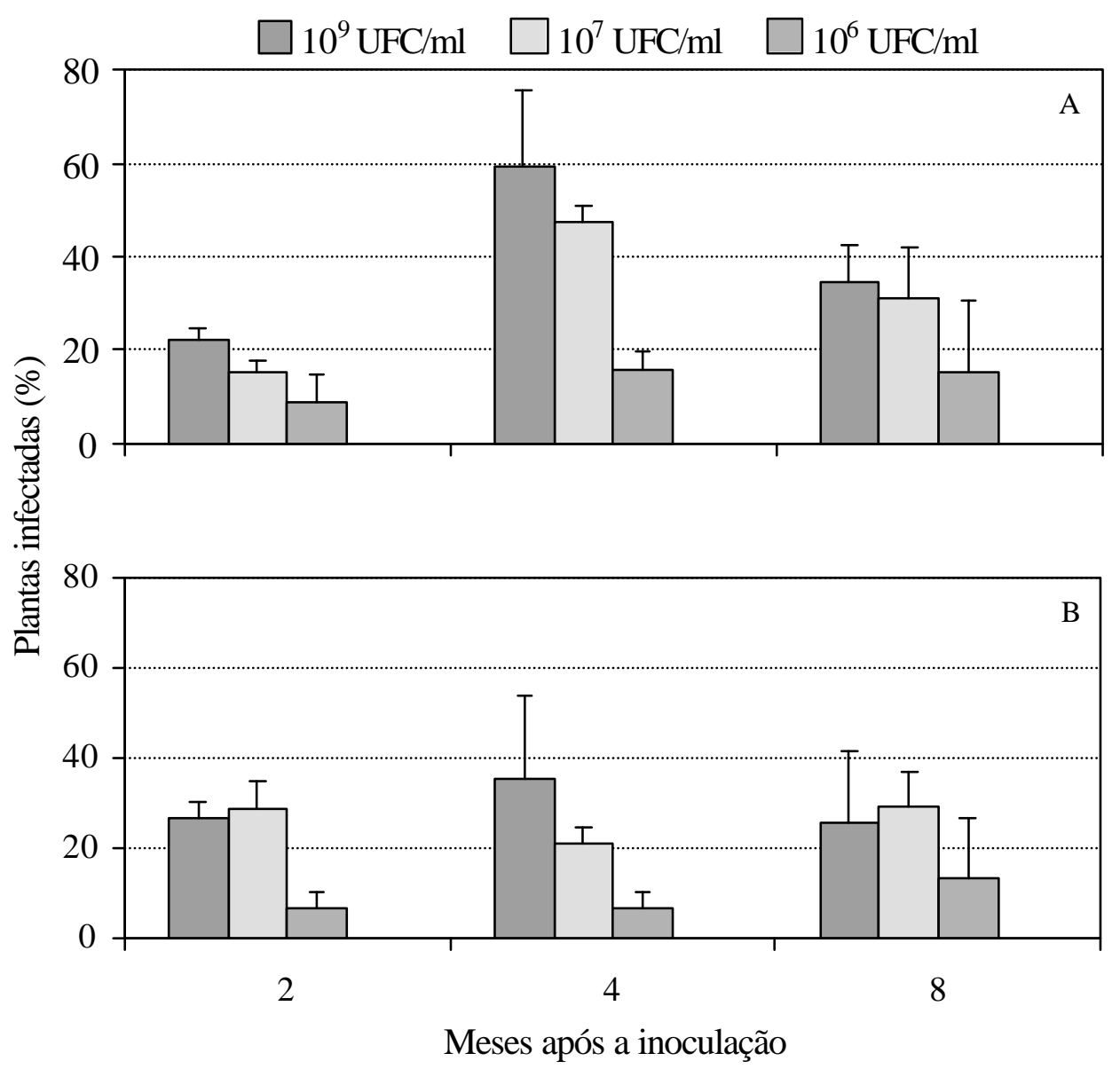

Figura 5 - Porcentagem média $( \pm$ EPM) de plantas de café positivas para Xylella fastidiosa por cultura (A) e PCR (B) após a inoculação por agulha de diferentes concentrações de células da estirpe de cafeeiro (ARC; isolado CCT6756) 


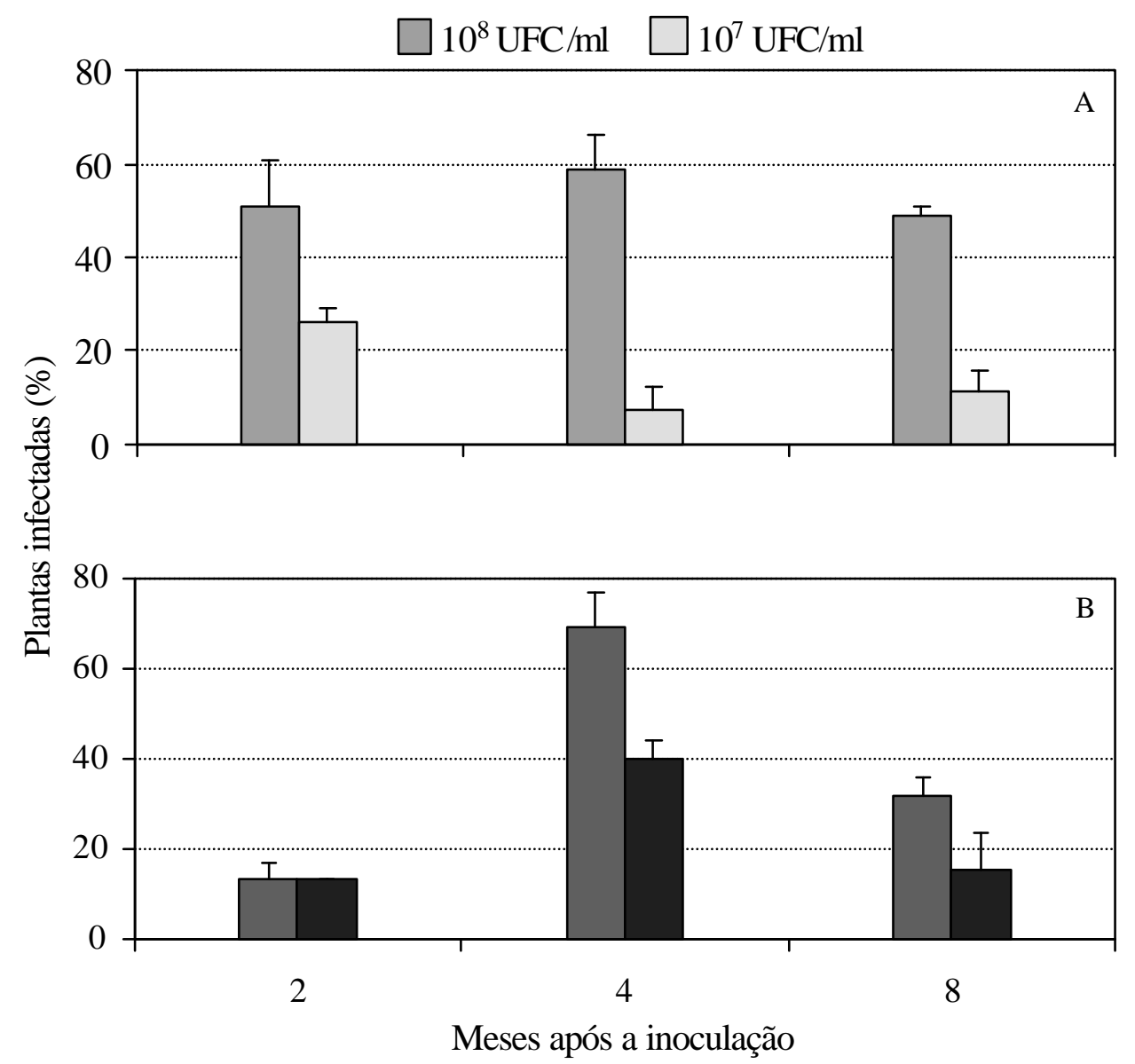

Figura 6 - Porcentagem média $( \pm$ EPM) de plantas cítricas positivas para Xylella fastidiosa por cultura (A) e PCR (B) após a inoculação por agulha de diferentes concentrações de células da estirpe de citros (CVC; isolado CCT6570). 


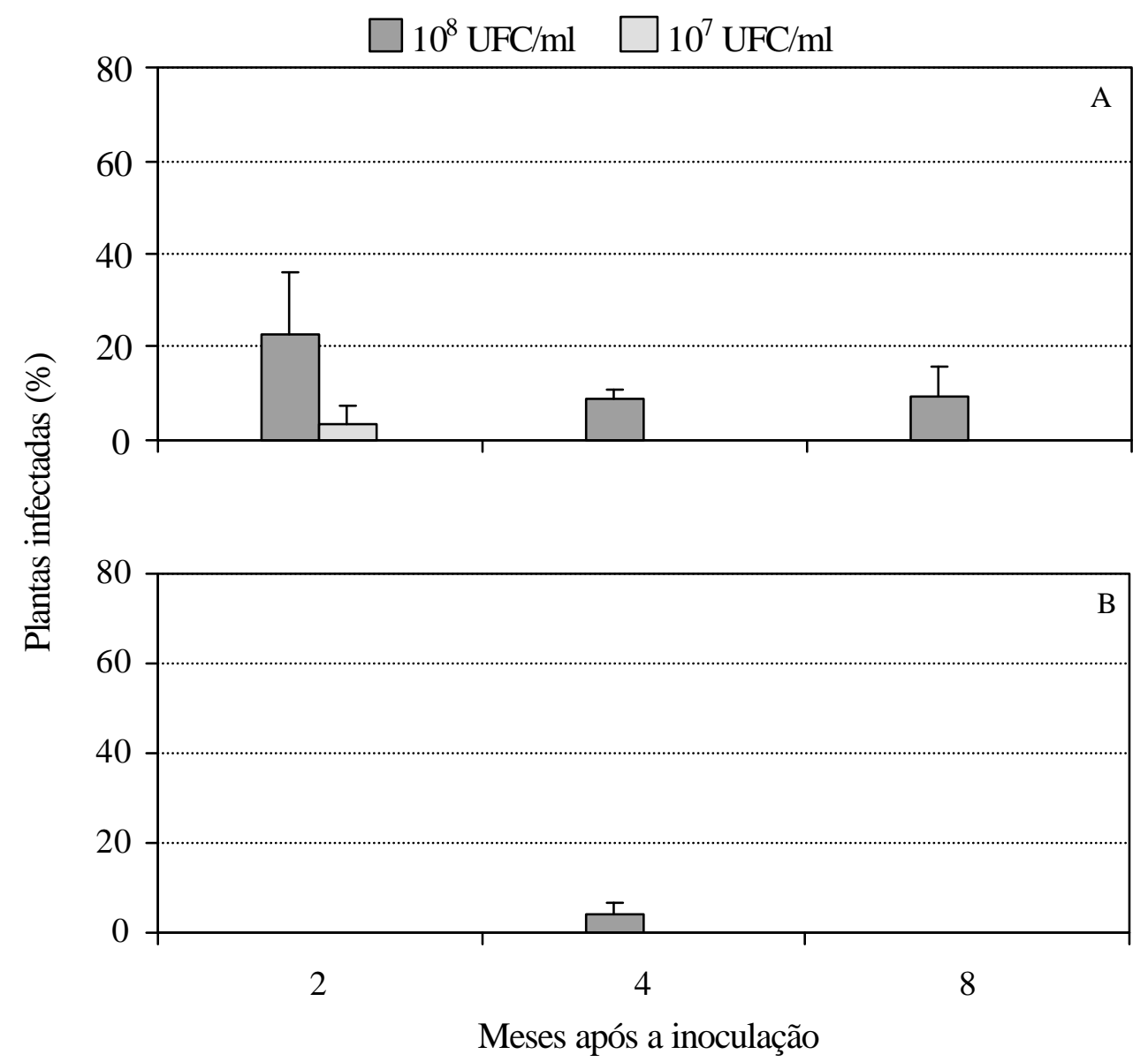

Figura 7 - Porcentagem média $( \pm$ EPM) de plantas de café positivas para Xylella fastidiosa por cultura (A) e PCR (B) após a inoculação por agulha de diferentes concentrações de células da estirpe de citros (CVC; isolado CCT6570) 


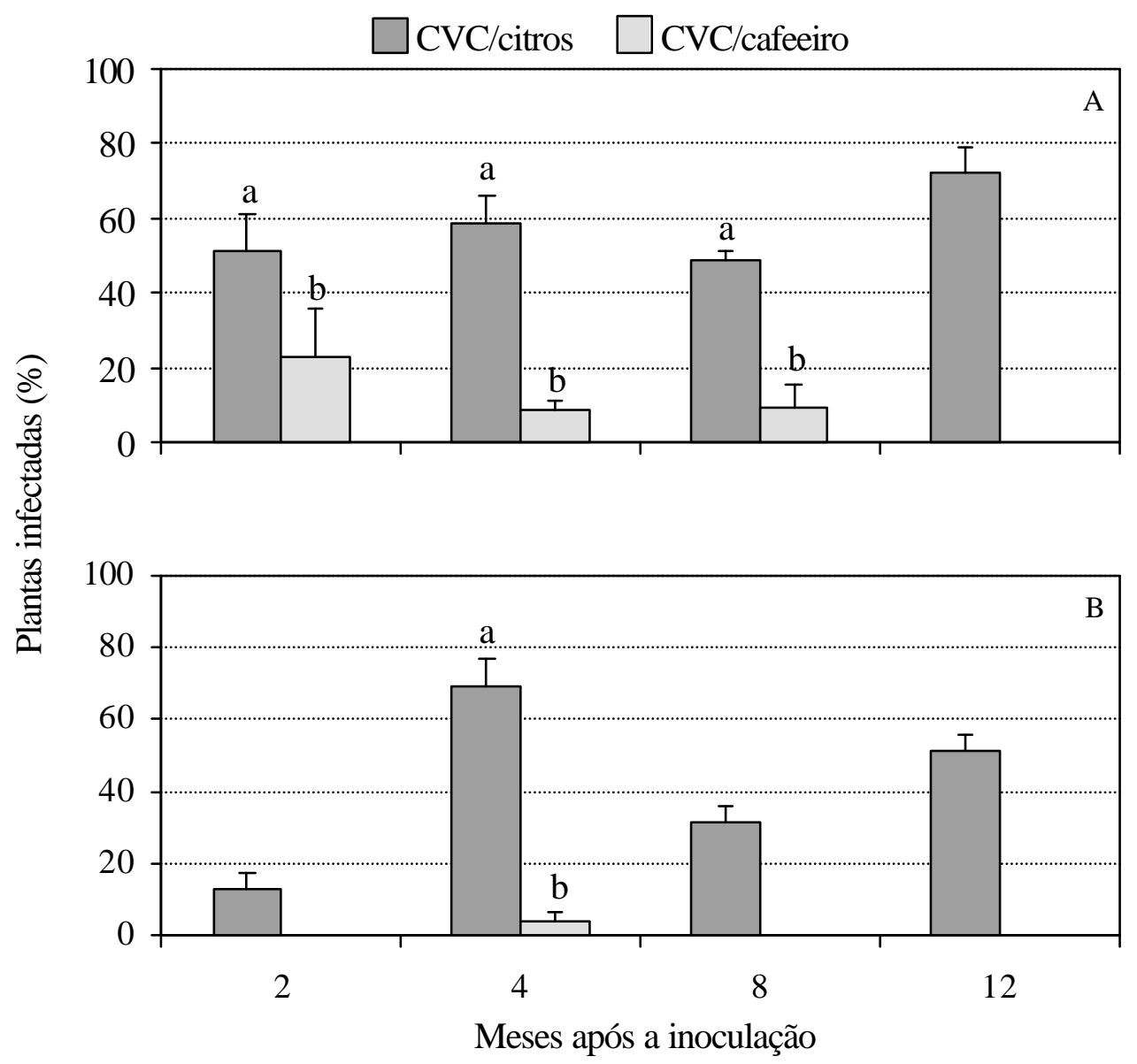

Figura 8 - Porcentagem média $( \pm$ EPM) de plantas de citros e de café positivas para Xylella fastidiosa por cultura (A) e PCR (B), em diferentes períodos após a inoculação por agulha de uma suspensão de células $\left(10^{8} \mathrm{UFC} / \mathrm{mL}\right)$ da estirpe de citros (CVC; isolado CCT6570). Para um mesmo período, médias com mesmas letras não diferem entre si pelo teste de Tukey $(\alpha=0,05)$ 
A comparação estatística entre as duas estirpes em combinações homólogas (CVC/citros x ARC/cafeeiro) não pôde ser realizada devido aos experimentos terem sido instalados em hospedeiros e dias diferentes, e apresentarem diferenças nas concentrações inoculadas. Entretanto, analisando-se os dados obtidos com a maior concentração de inóculo testada $\left(10^{8}\right.$ e $10^{9} \mathrm{UFC} / \mathrm{mL}$ em citros e cafeeiro, respectivamente) (Figura 4), observou-se que a inoculação da estirpe de citros resultou em maiores porcentagens cumulativas de plantas infectadas. Verificourse, também, um crescimento mais rápido na incidência de plantas positivas por cultura para a combinação CVC/citros, que atingiu cerca de $50 \%$ com apenas 2 meses após a inoculação no uso da maior concentração testada $\left(10^{8} \mathrm{UFC} / \mathrm{mL}\right)$.

Em estudo semelhante, $\mathrm{Li}$ et al. (2001) inocularam mecanicamente as estirpes de citros e de cafeeiro em plantas de café, sendo que cada planta-teste foi inoculada 20 vezes com a agulha acoplada a seringa. A concentração do inóculo variou de $10^{8}$ a $10^{9}$ UFC/mL. Após 8 meses da inoculação, a bactéria X. fastidiosa pôde ser detectada por PCR em 50\% (5 em 10) das plantas de café inoculadas com a estirpe de cafeeiro (isolado CLS-Xf3124) e em 70\% (7 em 10) das plantas de café inoculadas com a estirpe de citros (isolado CVC-Xf2105). Possivelmente, a maior incidência de infecção de cafeeiro pela estirpe de citros obtida por $\mathrm{Li}$ et al. (2001) se deve ao método de inoculação, que envolveu um volume de inóculo provavelmente maior que o utilizado na presente pesquisa $(5 \mu \mathrm{L})$. Além disso, é possível que o isolado de citros testado por Li et al. (2001) seja mais agressivo em cafeeiro que o utilizado nesta pesquisa.

As curvas de titulação e a dose efetiva (DE) foram calculadas utilizando-se os dados de incidência de plantas infectadas obtidos a partir do isolamento em meio de cultura aos 2, 4 e 8 meses após a inoculação, separadamente (Tabelas 3 a 5). Utilizaramse, também, os totais cumulativos de incidência obtidos por cultura e/ou PCR aos 8 meses. Os dados cumulativos de incidência foram particularmente adequados para a elaboração de curvas de titulação para X. fastidiosa, pois representam um registro global das infecções que se estabeleceram durante o período de 8 meses após a inoculação. Devido à distribuição irregular da bactéria nos vasos do xilema (Mizubuti et al., 1994; Alves, 2003), flutuação populacional (Hopkins, 1985) ou mesmo mortalidade bacteriana 
em certos hospedeiros (Purcell \& Saunders, 1999), os testes de PCR e de cultura podem não detectar todas as infecções existentes nas plantas-teste em avaliações isoladas, tais como aos 2, 4 ou 8 meses após a inoculação.

O modelo de regressão logístico foi usado para o logaritmo das doses de inóculo bacteriano. Os valores para o ajuste do modelo logístico com ou sem o fator de heterogeneidade para as combinações ARC/cafeeiro, $\mathrm{CVC} /$ citros e $\mathrm{CVC} /$ cafeeiro estão apresentados na Tabela 6. Em alguns casos, a "deviance" residual se distanciou do número de graus de liberdade, evidenciando o problema da dispersão dos dados. Nestes casos, o modelo é adequado quando o fator de heterogeneidade é incluído. $\mathrm{Na}$ combinação ARC/cafeeiro, os modelos logísticos adotados (com $\mathrm{P}<0,05$ ) possuem o preditor linear dado por uma regressão quadrática aos 2 e 4 meses após a inoculação e, por uma regressão linear aos 8 meses (Tabelas 6 e 7). Na combinação CVC/citros, os modelos logísticos mais adequados $(\mathrm{P}<0,01)$ possuem o preditor linear dado por uma regressão linear (Tabelas 6 e 8). Na combinação CVC/cafeeiro adotou-se o modelo logístico com o preditor linear dado por uma regressão linear $(\mathrm{P}<0,01)$ (Tabela 6 e 8). $\mathrm{Na}$ avaliação com os dados cumulativos os modelos logísticos adotados possuem o preditor linear dado por uma regressão quadrática (Tabela 6, 7 e 8).

Em geral, as curvas de titulação mostraram que a relação entre dose de inóculo e incidência de infecção é variável dependendo da combinação estirpe/hospedeiro. Para ARC/cafeeiro, as curvas obtidas após 4 e 8 meses da inoculação mostram um aumento significativo na proporção esperada de plantas infectadas a partir de uma concentração de inóculo de $\approx 10^{5} \mathrm{UFC} / \mathrm{mL}$ ( $\approx \ln 13$ ), ocorrendo estabilização na incidência de infecção com concentrações superiores a $10^{7} \mathrm{UFC} / \mathrm{mL}(\ln 16)$ (Figura 9 B,C). 
Tabela 6. Estatísticas obtidas ajustando-se o modelo logístico aos dados parciais de proporção de plantas positivas para Xylella fastidiosa por cultura aos 2, 4 e 8 meses após a inoculação, e para a proporção cumulativa aos 8 meses

\begin{tabular}{|c|c|c|c|c|c|c|}
\hline \multirow[b]{2}{*}{$\begin{array}{l}\text { Meses após } \\
\text { inoculação }\end{array}$} & \multirow[b]{2}{*}{$\begin{array}{l}\text { Combinação } \\
\text { estirpe/planta }\end{array}$} & \multirow{2}{*}{$\begin{array}{l}\text { F.H. }{ }^{1} \\
(\phi)\end{array}$} & \multirow[b]{2}{*}{ G.L. $^{2}$} & \multirow[b]{2}{*}{$\begin{array}{l}\text { "Deviance" } \\
\text { residual }\end{array}$} & \multicolumn{2}{|c|}{$\mathrm{P}^{4}$} \\
\hline & & & & & $\begin{array}{c}\text { Regressão } \\
\text { linear }\end{array}$ & $\begin{array}{l}\text { Regressão } \\
\text { quadrática }\end{array}$ \\
\hline \multirow{3}{*}{2} & ARC/cafeeiro & 0,74 & 8 & 9,40 & 0,001 & 0,040 \\
\hline & CVC/citros & 0,64 & 9 & 9,16 & $<0,001$ & 0,060 \\
\hline & CVC/cafeeiro & 1,00 & 9 & 10,85 & $<0,001$ & 0,856 \\
\hline \multirow{3}{*}{4} & ARC/cafeeiro & 1,00 & 8 & 10,29 & $<0,001$ & 0,003 \\
\hline & CVC/citros & 0,71 & 9 & 10,37 & $<0,001$ & 0,844 \\
\hline & CVC/cafeeiro & 0,25 & 9 & 8,53 & $<0,001$ & 0,846 \\
\hline \multirow{3}{*}{8} & ARC/cafeeiro & 1,58 & 9 & 9,19 & 0,023 & 0,108 \\
\hline & CVC/citros & 0,46 & 9 & 8,54 & $<0,001$ & 0,345 \\
\hline & $\mathrm{CVC} /$ cafeeiro & 0,87 & 9 & 9,60 & 0,009 & 0,922 \\
\hline \multirow{3}{*}{ Cumulativo } & ARC/cafeeiro & 1,49 & 9 & 9,76 & 0,001 & 0,536 \\
\hline & CVC/citros & 0,49 & 9 & 8,90 & $<0,001$ & 0,087 \\
\hline & CVC/cafeeiro & 0,60 & 9 & 9,72 & $<0,001$ & 0,892 \\
\hline
\end{tabular}

${ }^{1}$ Fator de heterogeneidade $(\phi)$;

${ }^{2}$ Graus de liberdade do resíduo;

${ }^{3}$ Semelhante à soma de quadrados numa análise de variância;

${ }^{4}$ Valor da probabilidade, $\mathrm{P}<0,05$ é significativo; 
Tabela 7. Equações baseadas no modelo logístico relacionando concentração de inóculo (dose) e proporção de plantas infectadas (p) por Xylella fastidiosa para a estirpe de cafeeiro (ARC) em plantas de café aos 2, 4, 8 meses após a inoculação

\begin{tabular}{cc}
$\begin{array}{c}\text { Meses após } \\
\text { inoculação }\end{array}$ & Equação \\
\hline 2 & $\ln \left(\frac{\hat{p}_{i}}{1-\hat{p}_{i}}\right)=-18,7244+1,8358 \ln ($ dose $)-0,0479 \ln (\text { dose })^{2}$ \\
4 & $\ln \left(\frac{\hat{p}_{i}}{1-\hat{p}_{i}}\right)=-34,0699+3,6577 \ln ($ dose $)-0,0962 \ln (\text { dose })^{2}$ \\
8 & $\ln \left(\frac{\hat{p}_{i}}{1-\hat{p}_{i}}\right)=-4,9957+0,2254 \ln ($ dose $)$ \\
$\ln \left(\frac{\hat{p}_{i}}{1-\hat{p}_{i}}\right)=-6,7498+0,4490 \ln ($ dose $)$
\end{tabular}

Equação obtida com dados cumulativos de proporção de plantas infectadas aos 8 meses após a inoculação. 
Tabela 8. Equações baseadas no modelo logístico relacionando concentração de inóculo (dose) e proporção de plantas infectadas (p) por Xylella fastidiosa para a estirpe de citros (CVC) em plantas de citros e de café aos 2, 4, 8 meses após a inoculação

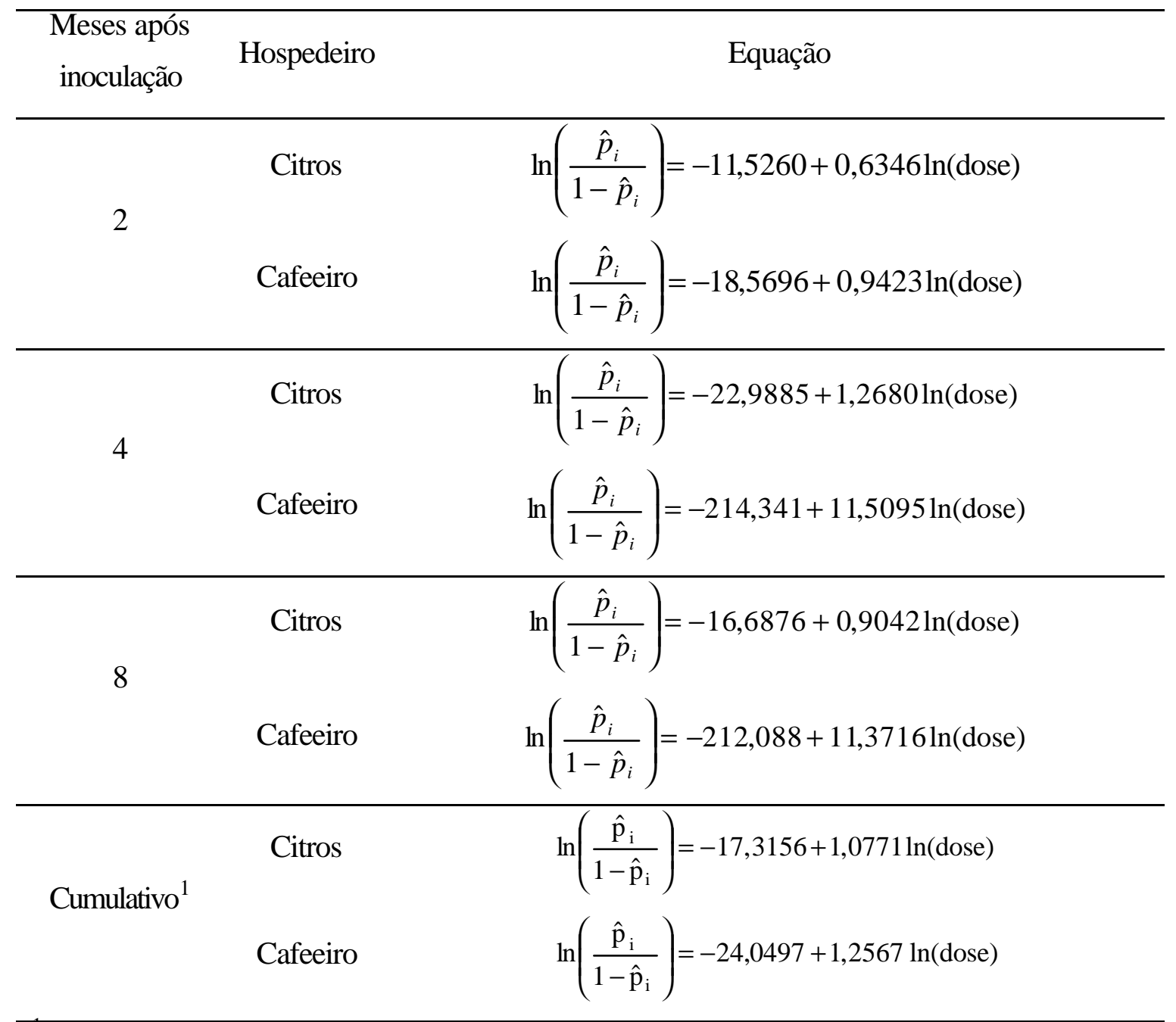

I Equações obtidas com dados cumulativos de porcentagem de plantas infectadas aos 8 meses após a inoculação. 

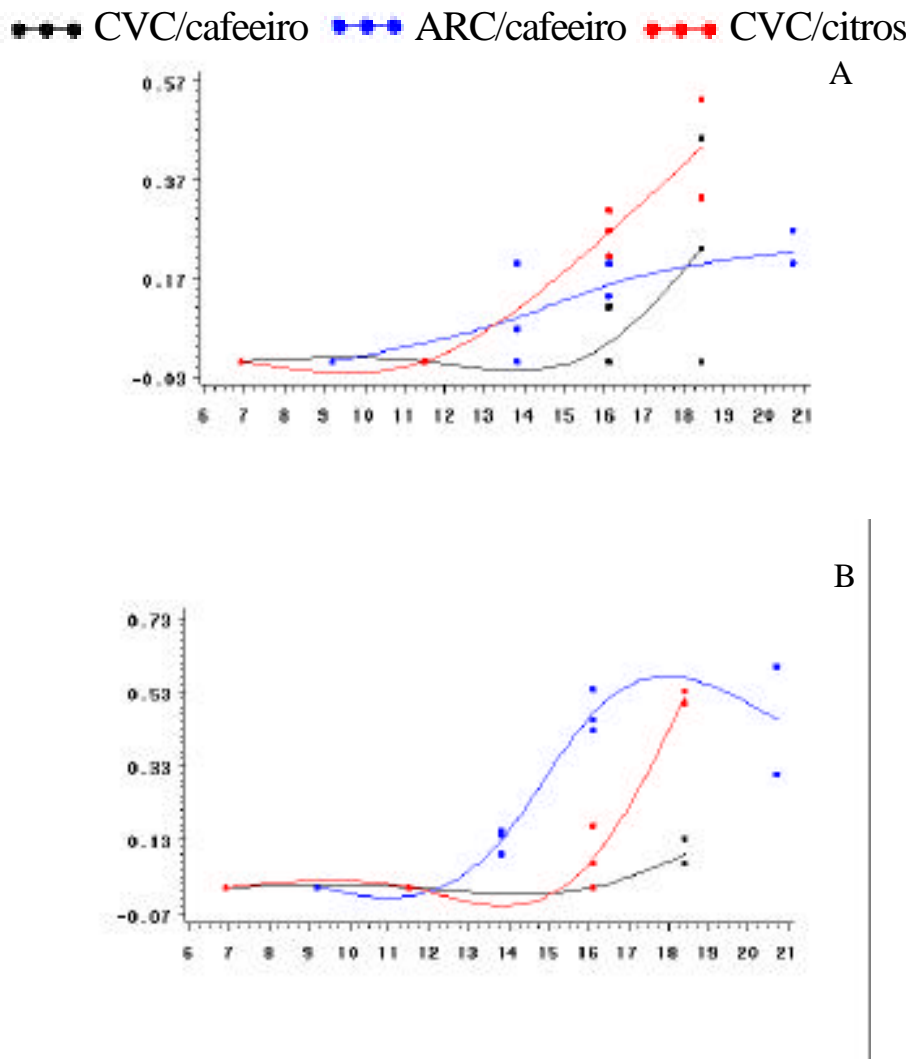

$\mathrm{C}$

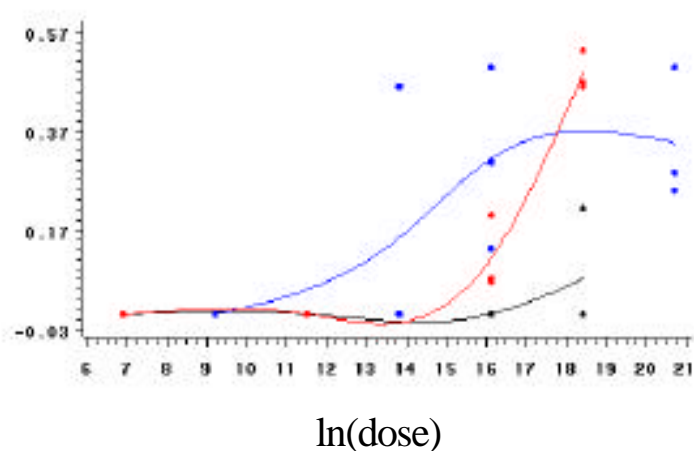

Figura 9 - Curvas de titulação obtidas para a relação entre concentração de inoculo (dose) e proporção de plantas infectadas por Xylella fastidiosa aos 2 (A), 4 (B) e 8 meses (C) após a inoculação das estirpes de cafeeiro (ARC) e de citros (CVC) em combinações homólogas (ARC/cafeeiro e CVC/citros) e heterólogas (CVC/cafeeiro) 
Para a combinação $\mathrm{CVC} /$ citros, ocorreu um aumento significativo na proporção esperada de infecção em concentrações de inóculo a partir de $10^{6} \mathrm{UFC} / \mathrm{mL}(\ln 15)$. Neste caso, entretanto, não se observou uma estabilização na curva de incidência com concentrações de até $10^{8} \mathrm{UFC} / \mathrm{mL}(\approx \ln 18)$ (Figura 9). Este fato sugere que doses mais elevadas da estirpe de citros poderiam resultar em maiores taxas de infecção em plantas cítricas. Já no caso da combinação heteróloga (CVC/cafeeiro), verificourse um aumento na incidência da infecção apenas com doses superiores a $10^{7} \mathrm{UFC} / \mathrm{mL}(\ln 16)$, baseandose na avaliação com 2 meses pós a inoculação (Figura 9A). Em avaliações posteriores (4 e 8 meses), a proporção de plantas infectadas foi muito baixa mesmo em doses superiores a $10^{7} \mathrm{UFC} / \mathrm{mL}(\ln 16)$ (Figura 9 B,C), talvez por morte de infecções primárias da bactéria após alguns meses da inoculação.

Analisando-se as curvas obtidas com dados cumulativos de infecção aos 8 meses, observou-se um crescimento na proporção esperada de infecção a partir de concentrações de inóculo de $10^{5} \mathrm{UFC} / \mathrm{mL}(\ln 13)$ para ambas as combinações homólogas (CVC/citros e ARC/cafeeiro), e de $10^{8} \mathrm{UFC} / \mathrm{mL}(\ln 18)$ para a heteróloga (CVC/cafeeiro) (Figura 10).

Após o ajuste do modelo logístico foram obtidas as equações e calculados os valores das doses efetivas (DE) (Tabela 9).

Para as combinações ARC/cafeeiro e CVC/citros 6ram calculados os valores de dose efetiva para $20 \%$ de plantas infectadas $\left(\mathrm{DE}_{20}\right)$ aos 2, 4 e 8 meses após a inoculação (Tabela 9). Na combinação CVC/cafeeiro, devido à baixa proporção de plantas infectadas nas avaliações aos 4 e 8 meses após a inoculação, não foi possível determinar as doses efetivas para $20 \%$ de plantas infectadas $\left(\mathrm{DE}_{20}\right)$, sendo determinada nestes casos, as doses efetivas para 5\% ( $\left.\mathrm{DE}_{5}\right)$ (Tabela 9). Na avaliação com os dados cumulativos, a baixa proporção de plantas infectadas obtidas na combinação CVC/cafeeiro impossibilitou a estimativa da dose efetiva para $50 \%$ de infecção $\left(\mathrm{DE}_{50}\right)$, determinandose, neste caso, a dose efetiva para 25\% ( $\mathrm{DE}_{25}$ ) (Tabela 9). Talvez, a utilização de um método mais eficiente de inoculação, ou a aplicação de maiores concentrações ou volumes de suspensão bacteriana, possibilitaria a estimativa de valores de DE para taxas de infecção superiores. 


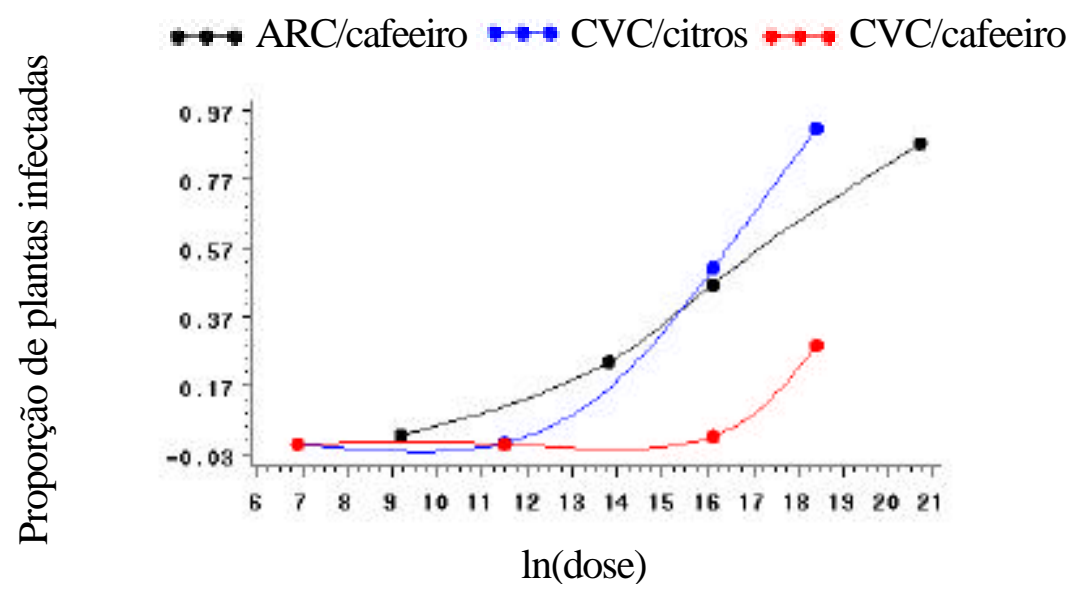

Figura 10 - Curvas de titulação obtidas para a relação entre concentração de inóculo (dose) e proporção cumulativa de plantas infectadas por Xylella fastidiosa aos 8 meses após a inoculação das estirpes de cafeeiro (ARC) e citros (CVC) em combinações homólogas (ARC/cafeeiro e CVC/citros) e heterólogas (CVC/cafeeiro) 
Tabela 9. Valores de dose efetiva (DE) obtidos para as inoculações de estirpes de Xylella fastidiosa em citros e cafeeiro, baseando-se em dados de proporção de plantas infectadas aos 2, 4 e 8 meses após a inoculação

\begin{tabular}{|c|c|c|c|c|}
\hline $\begin{array}{l}\text { Meses após } \\
\text { inoculação }\end{array}$ & $\begin{array}{l}\text { Combinação } \\
\text { Estirpe/planta }\end{array}$ & $\begin{array}{c}\mathrm{DE}_{5} \\
\left(\mathrm{UFC} / \mathrm{mL}^{2}\right)\end{array}$ & $\begin{array}{c}\mathrm{DE}_{20} \\
(\mathrm{UFC} / \mathrm{mL})\end{array}$ & $\begin{array}{c}\mathrm{DE}_{25} \\
(\mathrm{UFC} / \mathrm{mL})\end{array}$ \\
\hline \multirow{3}{*}{2} & ARC/cafeeiro & $0,45 \times 10^{6}$ & $0,21 \times 10^{8}$ & $-2^{2}$ \\
\hline & CVC/citros & $0,75 \times 10^{6}$ & $0,87 \times 10^{7}$ & - \\
\hline & CVC/cafeeiro & $0,16 \times 10^{8}$ & $0,83 \times 10^{8}$ & - \\
\hline \multirow{3}{*}{4} & ARC/cafeeiro & $0,38 \times 10^{6}$ & $0,17 \times 10^{7}$ & - \\
\hline & CVC/citros & $0,73 \times 10^{7}$ & $0,25 \times 10^{8}$ & - \\
\hline & CVC/cafeeiro & $0,83 \times 10^{8}$ & - & - \\
\hline \multirow{3}{*}{8} & ARC/cafeeiro & $0,90 \times 10^{4}$ & $0,90 \times 10^{7}$ & - \\
\hline & CVC/citros & $0,40 \times 10^{7}$ & $0,22 \times 10^{8}$ & - \\
\hline & CVC/cafeeiro & $0,97 \times 10^{8}$ & - & - \\
\hline \multirow{3}{*}{ Cumulativo $^{1}$} & ARC/cafeeiro & $0,48 \times 10^{4}$ & $0,15 \times 10^{6}$ & $0,29 \times 10^{6}$ \\
\hline & CVC/citros & $0,62 \times 10^{6}$ & $0,26 \times 10^{7}$ & $0,35 \times 10^{7}$ \\
\hline & CVC/cafeeiro & $0,20 \times 10^{8}$ & $0,68 \times 10^{8}$ & $0,85 \times 10^{8}$ \\
\hline
\end{tabular}

${ }^{1}$ Valores de DE obtidos com base em percentuais cumulativos de plantas infectadas aos 8 meses após a inoculação;

2 Número de unidades formadoras de colônias após isolamento primário em meio de cultura PWG por $\mathrm{mL}$;

3 -: valores não calculados.

Baseando-se nas curvas de titulação obtidas, determinourse a $\mathrm{DE}_{5}$ de $0,45 \times 10^{6}$ UFC/mL para ARC/cafeeiro e de 0,75 x $10^{6} \mathrm{UFC} / \mathrm{mL}$ para CVC/citros, aos 2 meses após a inoculação (Tabela 9; Figura 9A). Já para a combinação heteróloga CVC/cafeeiro, a $\mathrm{DE}_{5}$ foi de $0,16 \times 10^{8} \mathrm{UFC} / \mathrm{mL}$ aos 2 meses.

Para os dados cumulativos de infecção aos 8 meses, obtiveram-se valores de $\mathrm{DE}_{5}$ de $0,48 \times 10^{4} \mathrm{UFC} / \mathrm{mL}$ para ARC/cafeeiro, 0,62 × $10^{6} \mathrm{UFC} / \mathrm{mL}$ para CVC/citros e $0,20 \times 10^{8} \mathrm{UFC} / \mathrm{mL}$ para CVC/cafeeiro (Tabela 9). A $\mathrm{DE}_{25}$ (dose efetiva para $25 \%$ de 
infecção) para a combinação ARC/cafeeiro foi de $0,29 \times 10^{6} \mathrm{UFC} / \mathrm{mL}$, e para a CVC/citros foi de $0,35 \times 10^{7} \mathrm{UFC} / \mathrm{mL}$. Já para a combinação heteróloga CVC/cafeeiro, a $\mathrm{DE}_{25}$ foi de $0,85 \times 10^{8} \mathrm{UFC} / \mathrm{mL}$.

Calcularam-se intervalos de confiança para os valores de $\mathrm{DE}_{5}$ e $\mathrm{DE}_{20}$ obtidos aos 2, 4 e 8 meses após a inoculação. Para a combinação ARC/cafeeiro, houve sobreposição de todos os intervalos de confiança (Figura 11), indicando não haver diferença estatística entre as doses efetivas obtidas nos diferentes períodos de avaliação. Para a combinação CVC/citros, a comparação dos valores dos ntervalos de confiança mostra que os valores de $\mathrm{DE}_{5}$ e de $\mathrm{DE}_{20}$ aos 2 meses após a inoculação são significativamente menores que os observados aos 4 meses (Figura 12).

A comparação dos intervalos de confiança obtidos para as combinações CVC/citros e CVC/cafe eiro tanto na avaliação aos 2 meses (Figuras 12A e B) quanto na avaliação cumulativa (Figura 13), demonstrou que as doses efetivas $\left(\mathrm{DE}_{5}, \mathrm{DE}_{20}\right.$ e $\left.\mathrm{DE}_{25}\right)$ foram maiores em cafeeiro. Estes resultados demonstraram que a estirpe de citros precisa de uma maior concentração de inóculo para infectar plantas de café do que para infectar plantas de citros. Isto ocorre, provavelmente, devido a uma menor capacidade da bactéria em colonizar uma planta hospedeira diferente da planta de origem.

A reduzida colonização do cafeeiro pela estirpe de citros ocorreu, possivelmente, devido a limitações ao movimento da bactéria nos vasos do xilema, o que pode ter resultado em perda de virulência. A estirpe de citros também poderia estar agindo como uma estirpe não virulenta em cafeeiro, onde a taxa de multiplicação inicial seria semelhante a das estirpes virulentas e, no entanto, após atingir um pico entraria em declínio, chegando a morrer na planta (Hopkins, 1985). 


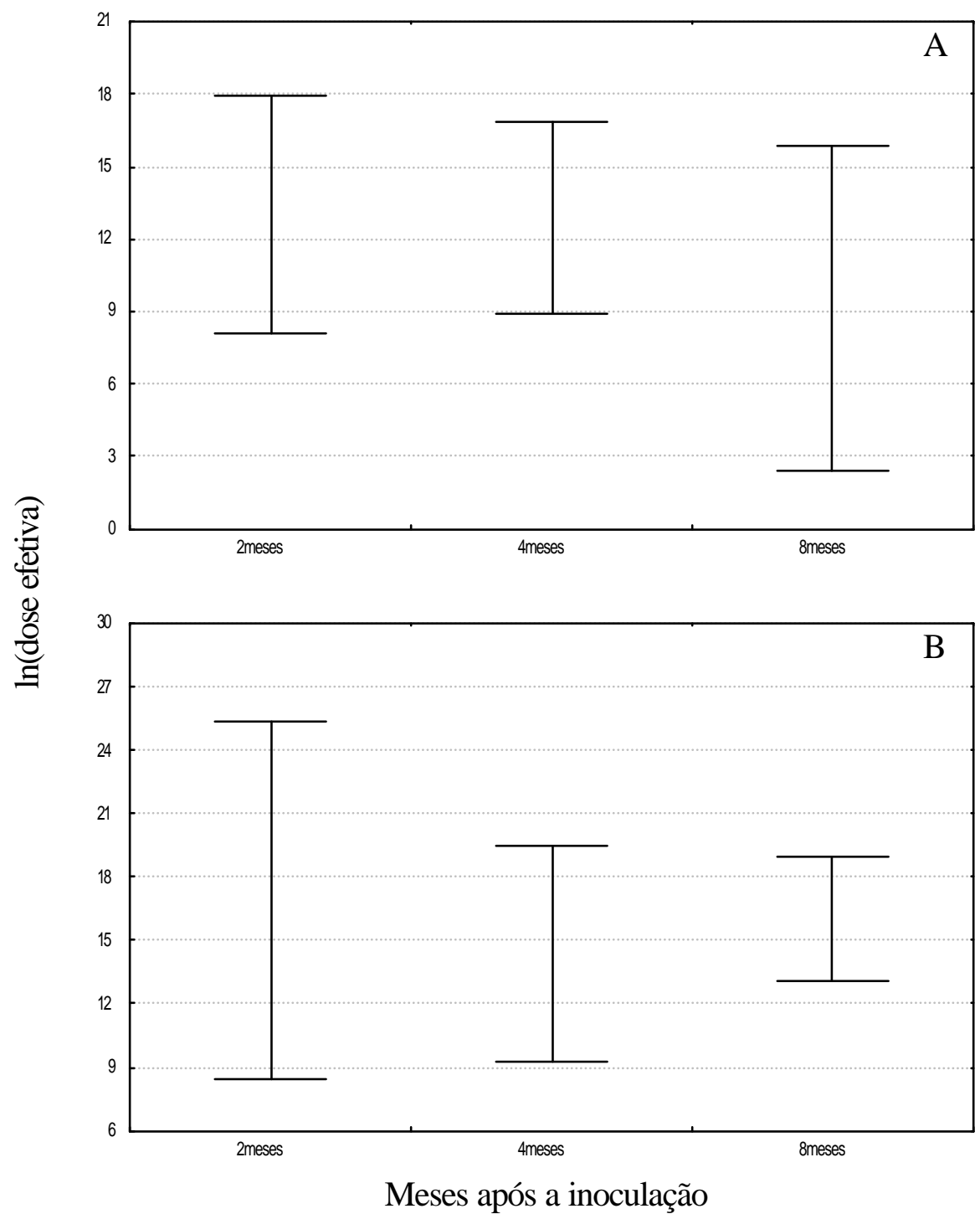

Figura 11 - Intervalos de confiança para $\mathrm{DE}_{5}(\mathrm{~A})$ e $\mathrm{DE}_{20}$ (B) obtidos para a estirpe de cafeeiro (ARC) de Xylella fastidiosa em plantas de café aos 2, 4 e 8 meses após a inoculação 


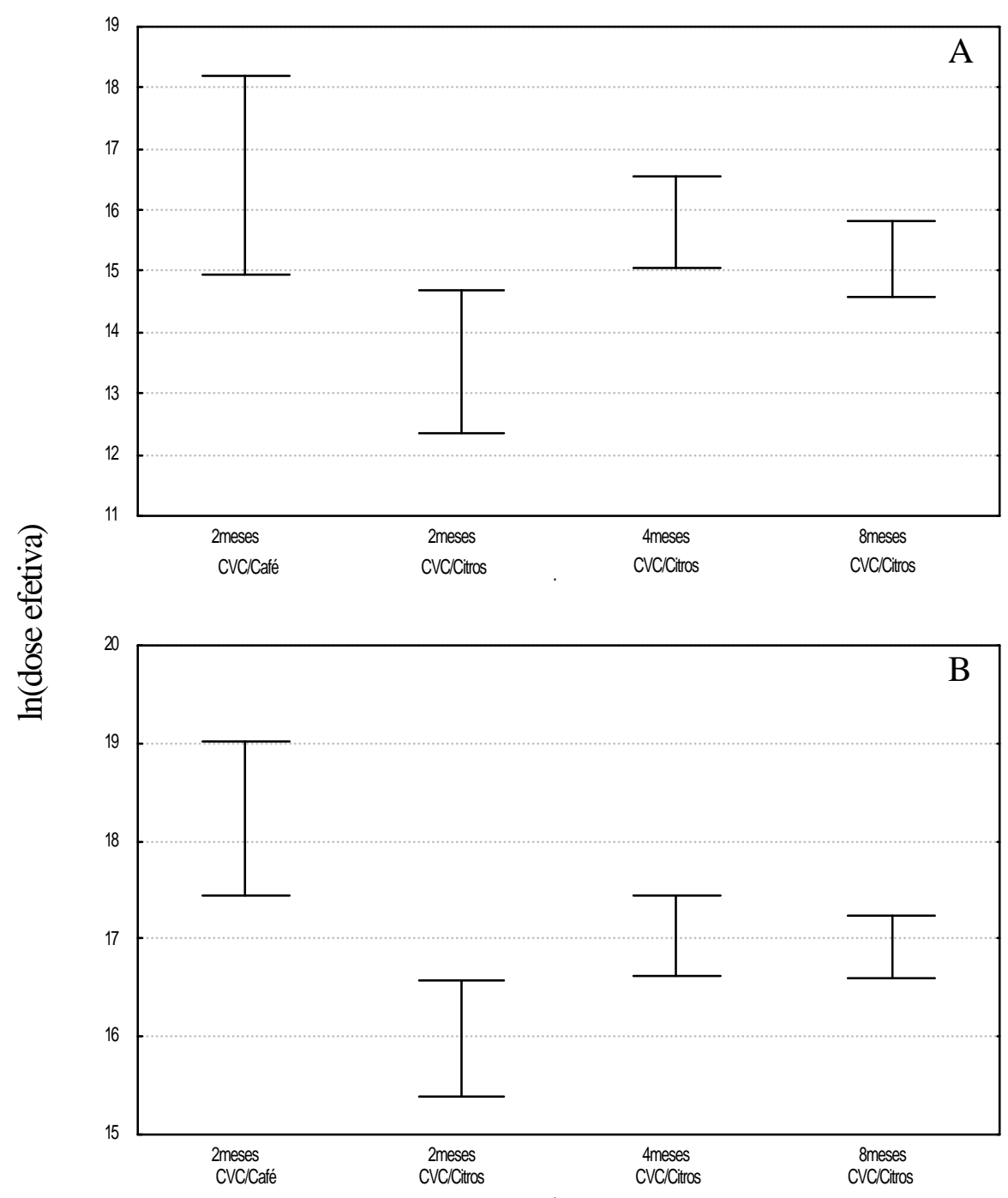

Figura 12 - Intervalos de confiança para $\mathrm{DE}_{5}(\mathrm{~A})$ e $\mathrm{DE}_{20}(\mathrm{~B})$ obtidos para a estirpe de citros (CVC) de Xylella fastidiosa em plantas de café e de citros aos 2, 4 e 8 meses após a inoculação 


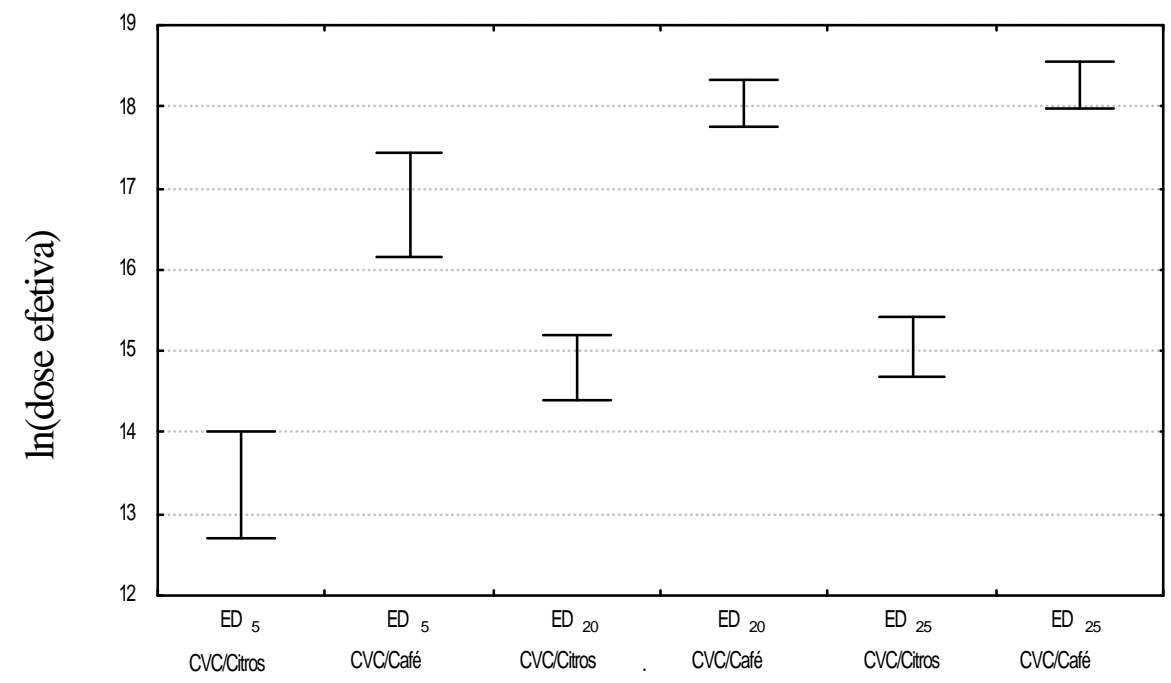

Figura 13 - Intervalos de confiança para $\mathrm{DE}_{5,20}$ e 25 obtidos para a estirpe de citros (CVC) de Xylella fastidiosa em plantas de citros e de café, baseados em dados cumulativos de infecção após 8 meses da inoculação

Através da determinação das curvas de titulação e da dose efetiva pode-se observar que a estirpe de cafeeiro demanda concentrações de inóculo mais baixas que a estirpe de citros para a obtenção de proporções mais elevadas de infecção de plantas em combinações homólogas. Isto sugere que o cafeeiro seja um hospedeiro mais facilmente colonizável, talvez devido a diferentes fatores químicos, fisiológicos ou mesmo morfológicos existentes nas plantas, que possam facilitar a translocação de $X$. fastidiosa no interior deste hospedeiro (Alves, 2003). Barbosa (2003) levantou a hipótese de que $X$. fastidiosa seja um organismo endofítico em cafeeiro, mas que pode causar danos e provocar sintomas em condição de estresse da planta. Esta hipótese é reforçada pelo fato de que nos dois experimentos de inoculação (4.2 e 4.3) as plantas de café infectadas não apresentaram nenhum sintoma típico relatado para a doença $\mathrm{ARC}$, enquanto que várias plantas da combinação CVC/citros apresentaram sintomas de CVC. 
O método de isolamento em meio de cultura permitiu não só a detecção, mas também a quantificação bacteriana presente no interior da planta. Para a combinação ARC/cafeeiro, não houve diferença significativa em população bacteriana entre as concentrações de inóculo $\left(10^{9}, 10^{7}\right.$ e $\left.10^{6} \mathrm{UFC} / \mathrm{mL}\right)$ aos $2(\mathrm{~F}=2,70 ; \mathrm{P}=0,093), 4$ ( $\mathrm{F}=$ $1,14 ; \mathrm{P}=0,330)$ e 8 meses $(\mathrm{F}=1,86 ; \mathrm{P}=0,172)$ após a inoculação (Tabela 10). Para a combinação CVC/citros, também não ocorreu diferença significativa na população bacteriana entre as concentrações $\left(10^{8}\right.$ e $\left.10^{7} \mathrm{UFC} / \mathrm{mL}\right)$ aos $2(\mathrm{~F}=4,08 ; \mathrm{P}=0,049), 4(\mathrm{~F}=$ $0,43 ; \mathrm{P}=0,522)$ e 8 meses $(\mathrm{F}=0,73 ; \mathrm{P}=0,594)$.

A população bacteriana na combinação ARC/cafeeiro foi mais baixa aos 2 meses após a inoculação, atingindo picos aos 4 meses para as concentrações de inoculo de $10^{9}$ $(\mathrm{F}=8,81 ; \mathrm{P}<0,001), 10^{7}$ (F = 4,66; $\left.\mathrm{P}=0,016\right)$ e $10^{6}$ (F=12,24; $\left.\mathrm{P}<0,001\right) \mathrm{UFC} / \mathrm{mL}$. Para a combinação CVC/citros, a população bacteriana foi semelhante aos 2 e 4 meses, apresentando uma redução aos 8 meses, na concentração de $10^{8} \mathrm{UFC} / \mathrm{mL}(\mathrm{F}=7,02 ; \mathrm{P}=$ 0,002). Na concentração de $10^{7} \mathrm{UFC} / \mathrm{mL}$, a população não diferiu significativamente ao longo dos meses $(\mathrm{F}=1,34 ; \mathrm{P}=0,29)$ (Tabela 10), embora seja perceptível uma tendência de queda aos 8 meses. Constratando-se os dois hospedeiros, observa-se que a população cultivável de $X$. fastidiosa mantém-se estável em citros entre 2 e 4 meses após a inoculação, enquanto que em cafeeiro ainda ocorre crescimento neste mesmo período.

Analisando-se as populações de $X$. fastidiosa nas infecções homólogas (ARC/cafeeiro e CVC/citros) durante um período de até 12 meses, observou-se uma flutuação populacional de células cultiváveis semelhante em ambos os hospedeiros, com tendência de aumento aos 4 e 12 meses após a inoculação (Figura 14), que coincidiram com os períodos de outono (junho/julho) e verão (fevereiro/março), respectivamente, e de queda aos 8 meses na primavera (outubro/novembro). A partir dos 4 meses após a inoculação, a população bacteriana em cafeeiro apresentou-se superior à observada em citros. 
Tabela 10. População cultivável de Xylella fastidiosa em plantas de café e de citros, após vários meses da inoculação de suspensões de células das estirpes de citros (CVC) e de cafeeiro (ARC), respectivamente

\begin{tabular}{|c|c|c|c|c|}
\hline \multirow[t]{2}{*}{ Estirpe/planta } & \multirow{2}{*}{$\begin{array}{l}\text { Concentrações } \\
\text { de inoculo } \\
(\mathrm{UFC} / \mathrm{mL})^{1}\end{array}$} & \multicolumn{3}{|c|}{$\begin{array}{c}\text { População bacteriana média } \\
\left(\mathrm{Log}_{\mathrm{UFC}} \mathrm{g} \text { de tecido }\right. \\
2 \\
\left. \pm \mathrm{EPM}^{3}\right)\end{array}$} \\
\hline & & 2 meses & 4 meses & 8 meses \\
\hline \multirow{3}{*}{$\begin{array}{c}\text { ARC/cafeeiro } \\
\text { (Experimento 1) }\end{array}$} & $10^{9}$ & $5,25 \pm 0,2 \mathrm{aB}^{4}$ & $5,86 \pm 0,1 \mathrm{aA}$ & $5,01 \pm 0,2 \mathrm{aB}$ \\
\hline & $10^{7}$ & $5,56 \pm 0,3 \mathrm{aAB}$ & $5,99 \pm 0,1 \mathrm{aA}$ & $5,37 \pm 0,2 \mathrm{aB}$ \\
\hline & $10^{6}$ & $4,66 \pm 0,2 \mathrm{aB}$ & $5,63 \pm 0,2 \mathrm{aA}$ & $5,58 \pm 0,1 \mathrm{aA}$ \\
\hline CVC/citros & $10^{8}$ & $5,36 \pm 0,1 \mathrm{aA}$ & $5,50 \pm 0,2 \mathrm{aA}$ & $4,77 \pm 0,1 \mathrm{aB}$ \\
\hline (Experimento 2) & $10^{7}$ & $4,98 \pm 0,1 \mathrm{aA}$ & $5,14 \pm 0,3 \mathrm{aA}$ & $4,54 \pm 0,2 \mathrm{aA}$ \\
\hline \multicolumn{5}{|c|}{$\begin{array}{l}\text { ' Número de unidades formadoras de colônias por mL de tampão fosfato salino; } \\
2 \text { Número de unidades formadoras de colônias após isolamento primário em meio de } \\
\text { cultura PWG; }\end{array}$} \\
\hline \multicolumn{5}{|c|}{${ }^{3}$ Erro padrão da média; } \\
\hline
\end{tabular}




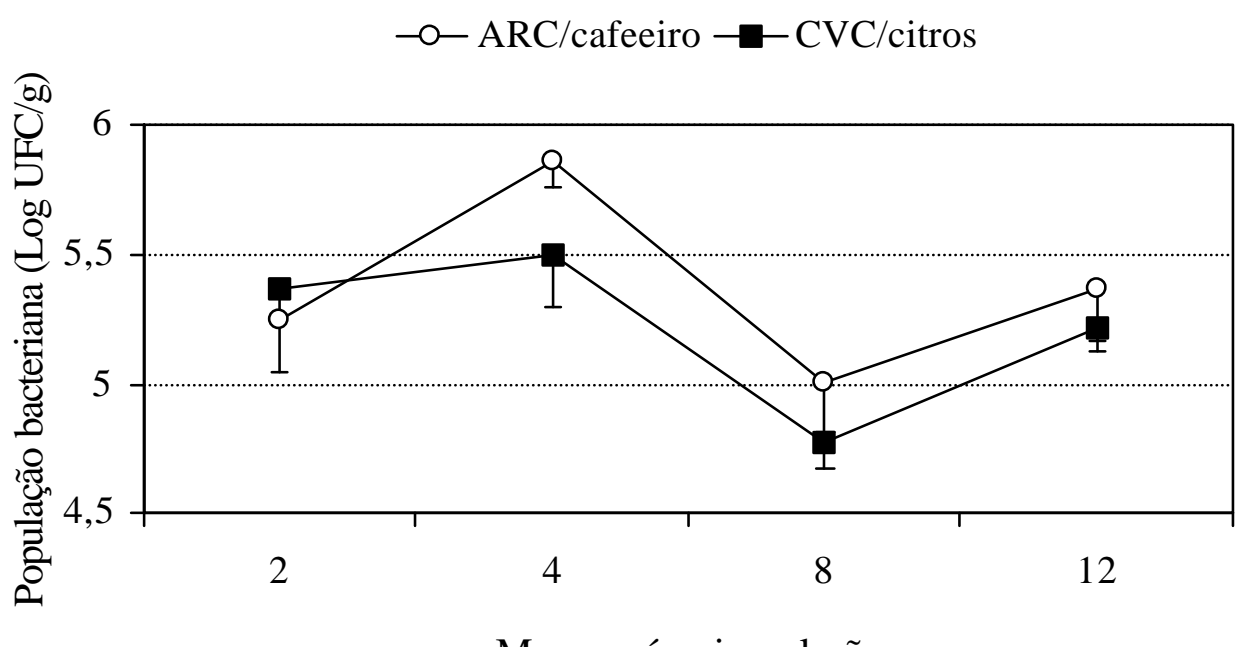

Meses após a inoculação

Figura 14 - População média ( \pm EPM) de Xylella fastidiosa em plantas de café e de citros, em períodos sucessivos após a inoculação de uma suspensão de células das estirpes de cafeeiro (ARC; $\left.10^{9} \mathrm{UFC} / \mathrm{mL}\right)$ e de citros (CVC; $10^{8}$ $\mathrm{UFC} / \mathrm{mL})$ 
A comparação da estirpe de citros em plantas de citros e de cafeeiro, na maior concentração de inóculo $\left(10^{8} \mathrm{UFC} / \mathrm{mL}\right)$, demonstrou que a população bacteriana atinge níveis mais altos em citros do que em cafeeiro. Isto ocorreu em todas as épocas de avaliação, embora a diferença tenha sido significativa apenas aos 2 meses $(F=17,3 ; P=$ 0,001) (Tabela 11). Estes resultados diferem dos obtid os no item 4.2, em que a população bacteriana na combinação homóloga foi significativamente superior à obtida na combinação heteróloga, também aos 4 meses após a inoculação.

Tabela 11. População cultivável de Xylella fastidiosa em plantas de citros e de café após vários meses da inoculação de uma suspensão de células $\left(10^{8} \mathrm{UFC} / \mathrm{mL}\right)$ da estirpe de citros

\begin{tabular}{cccc}
\hline \multirow{2}{*}{ Estirpe/planta } & \multicolumn{3}{c}{ População bacteriana média $\left(\right.$ Log UFC $1 / \mathrm{g}$ de tecido $\left.\pm \mathrm{EPM}^{2}\right)$} \\
\cline { 2 - 4 } & 2 meses & 4 meses & 8 meses \\
\hline CVC/citros & $5,36 \pm 0,1 \mathrm{aA}^{3}$ & $5,50 \pm 0,2 \mathrm{aA}$ & $4,77 \pm 0,1 \mathrm{aB}$ \\
CVC/cafeeiro & $4,51 \pm 0,2 \mathrm{bA}$ & $4,89 \pm 0,2 \mathrm{aA}$ & $4,59 \pm 0,4 \mathrm{aA}$
\end{tabular}

\footnotetext{
' Número de unidades formadoras de colônias após isolamento primário em meio de cultura PWG;

${ }^{2}$ Erro padrão da média;

3 Médias seguidas de mesma letra minúscula na coluna ou maiúscula na linha, não diferem entre si pelo teste Tukey $(\alpha<0,05)$.
}

De um modo geral, a população bacteriana das estirpes de cafeeiro e de citros nas plantas variou de $10^{4}$ a $10^{6} \mathrm{UFC} / g$ de tecido. Essas médias populacionais são semelhantes às obtidas por Almeida et al. (2001) em citros, que inocularam o mesmo isolado (CCT6570) da estirpe de citros nas concentrações de $10^{6}$ e $10^{8} \mathrm{UFC} / \mathrm{mL}$.

Os resultados dos experimentos de inoculação cruzada de citros e de cafeeiro com diferentes concentrações de inóculo de X. fastidiosa demonstram que esta metodologia é adequada para avaliar a virulência das estirpes, a susceptibilidade das plantas hospedeiras e sua relação com a bactéria, conforme constatado para outros fitopatógenos (Ercolani, 1984; Lopes et al., 2001). 
A bactéria $X$. fastidiosa é patogênica a algumas espécies de plantas, em geral frutíferas, mas possui uma vasta gama de hospedeiros alternativos, que podem servir também como fonte de inóculo para a transmissão de $X$. fastidiosa pelos insetos vetores (Lopes et al., 2003). Algumas estirpes da bactéria podem provocar doenças em mais de um hospedeiro, como a estirpe de videira que causa a doença de Pierce ("Pierce's disease" - PD) em videira e escaldadura das folhas em amendoeira ("Almond leaf scorch" - ALS). Outras estirpes causam doenças somente nos hospedeiros de origem, como a estirpe de olmo e de plátano (Sherald, 1993).

Com relação à epidemiologia da CVC, é importante levar em consideração o fato de pomares cítricos estarem plantados em áreas adjacentes a cafezais que podem apresentar a bactéria X. fastidiosa endofiticamente (Barbosa, 2003). Devido à presença de insetos vetores comuns transitando em pomares cítricos e cafezais (Lopes et al., 1998; Marucci, 2003), há a possibilidade dos cafezais estarem servindo tanto de fonte de inóculo para a cigarrinhas adquirirem o patógeno e transmiti-lo para as plantas cítricas (ou vice versa), como de reservatório onde a bactéria pode se multiplicar e sobreviver na ausência de citros. Entretanto, a partir dos resultados apresentados neste trabalho, pôdese observar que as combinações heterólogas (CVC/cafeeiro e ARC/citros) resultam em infectividade baixa ou nula. O estudo de infectividade através das inoculações cruzadas mostrou que a estirpe de citros de $X$. fastidiosa coloniza as plantas de café, mas depois de 12 meses não é mais detectada por cultura ou PCR, o que sugere uma baixa sobrevivência neste hospedeiro após as infecções primárias. Assim, é possível que o cafeeiro sirva como fonte de inóculo para aquisição e transmissão da estirpe de citros pelas cigarrinhas vetoras, mas talvez por um período de tempo limitado.

Deve-se salientar que, em outro estudo, a estirpe de citros mostrou-se patogênica ao cafeeiro, causando sintomas semelhantes aos da doença ARC (Li et al., 2001). Neste estudo, verificou-se que a taxa inicial de multiplicação da estirpe de citros na planta cítrica foi maior do que na de café, o que pode reduzir a eficiência de aquisição e subseqüente transmissão desta estirpe por vetores a partir do cafeeiro. Hill \& Purcell (1997) mostraram que baixas populações de células cultiváveis em plantas-fonte reduzem a eficiência de transmissão de $X$. fastidiosa por vetores para plantas-teste. Esses 
autores não observaram transmissão por vetores quando a população bacteriana nas plantas-fonte foram menores que $10^{4} \mathrm{UFC} / \mathrm{g}$ de tecido.

$X$. fastidiosa não foi detectada em nenhuma planta cítrica inoculada com a estirpe de cafeeiro. Assim, cafezais infectados com a estirpe de cafeeiro provavelmente não servem como fonte de inóculo para a disseminação primária da CVC em pomares de laranja, a não ser que o cafezal esteja infectado com a estirpe de citros. Estudos de inoculação cruzada utilizando-se insetos vetores devem ser realizados para sustentar melhor estas previsões, considerando-se que até o momento foram usados apenas métodos artificiais de inoculação, com resultados variáveis.

Alguns autores especulam que a associação de X. fastidiosa com o cafeeiro, causando a doença ARC, pode ser mais antiga que a CVC em citros, pelo fato dos cafezais serem plantados há mais tempo que citros e pela bactéria já estar amplamente disseminada em cafezais no Brasil (Paradela et al., 1995; Li et al., 2001). Postula-se que a estirpe de cafeeiro de $X$. fastidiosa teria sofrido recombinações gênicas, dando origem a uma estirpe que $\mathbf{e}$ adaptou a citros. Esta hipótese poderia explicar a não detecção da estirpe de cafeeiro nas plantas de citros, uma vez que esta estirpe não estaria adaptada e, portanto, não conseguiria se desenvolver nas plantas de citros. Segundo Fry \& Milholland, (1990), a inibição da multiplicação e translocação bacteriana em algumas plantas pode ser atribuída a barreiras estruturais, inibidores ou substâncias químicas presentes nas plantas, que interferem nos graus de virulência.

\subsection{Variações em morfologia e crescimento de colônias em meio de cultura entre estirpes de $X$.fastidiosa de citros e de cafeeiro}

O período de incubação das colônias de $X$. fastidiosa no primeiro experimento variou de 5 a 7 dias para os isolados de citros e de 7 a 8 dias para os isolados de cafeeiro (Tabela 12). No segundo experimento, os períodos foram de 5 a 8 dias para os isolados de citros e de 6 a 7 dias para os isolados de cafeeiro (Tabela 13). Estes valores são próximos aos obtidos por Chang et al. (1993), que obtiveram colônias da estirpe de citros de X. fastidiosa no meio PW em 5 dias, e em PD2 ou CS20 após 7 a 10 dias. Em 
isolamento primário, Almeida et al. (2001) observaram um período de incubação de 7 a 8 dias para o isolado de citros CCT6570 nos meios PW e PWG e de 14 a 15 dias no meio BCYE.

Tabela 12. Período de incubação, diâmetro de colônias e coloração do meio de cultura PWG para três isolados de Xylella fastidiosa provenientes de citros e três de cafeeiro

\begin{tabular}{cccccc}
\hline $\begin{array}{c}\text { Hospedeiro } \\
\text { de origem }\end{array}$ & Isolado & $\begin{array}{c}\text { Período de } \\
\text { incubação } \\
\text { (dias) }\end{array}$ & $\begin{array}{c}\text { Diâmetro médio } \\
\text { de colônias } \pm \\
\text { EPM }^{1}\end{array}$ & $\begin{array}{c}\text { Intervalo de } \\
\text { variação } \\
\text { (mm) }\end{array}$ & $\begin{array}{c}\text { Coloração do } \\
\text { meio após } 30 \\
\text { dias }\end{array}$ \\
\hline \multirow{2}{*}{ Citros } & CCT6570 & 5 & $0,90 \pm 0,03 \mathrm{a}^{2}$ & $0,36-1,70$ & $\begin{array}{c}\text { Avermelhado } \\
\end{array}$ \\
& 18 & 7 & $0,61 \pm 0,05 \mathrm{c}$ & $0,20-0,89$ & $\begin{array}{c}\text { Avermelhado } \\
\text { Cafeeiro }\end{array}$ \\
& CCT6756 & $5-6$ & $0,61 \pm 0,02 \mathrm{c}$ & $0,37-0,78$ & Avermelhado \\
\hline \multirow{3}{*}{ C. } & 32 & 8 & $0,54 \pm 0,04 \mathrm{c}$ & $0,23-0,97$ & Alaranjado \\
& 33 & 7 & $0,72 \pm 0,07 \mathrm{~b}$ & $0,35-1,17$ & Alaranjado \\
\hline
\end{tabular}

${ }^{1}$ Erro padrão da média;

${ }^{2}$ Médias seguidas de mesma letra não diferem entre si pelo teste de Tukey (á < 0,05). 
Tabela 13. Período de incubação, diâmetro de colônias e coloração do meio de cultura PWG, para seis isolados de Xylella fastidiosa, provenientes de citros e seis de cafeeiro

\begin{tabular}{|c|c|c|c|c|c|}
\hline $\begin{array}{c}\text { Hospedeiro } \\
\text { de origem }\end{array}$ & Isolado & $\begin{array}{l}\text { Período de } \\
\text { incubação } \\
\text { (dias) }\end{array}$ & $\begin{array}{c}\text { Diâmetro médio } \\
\text { de colônias } \pm \\
\text { EPM }^{1}\end{array}$ & $\begin{array}{l}\text { Intervalo de } \\
\text { variação } \\
\text { (mm) }\end{array}$ & $\begin{array}{c}\text { Coloração do } \\
\text { meio após } 30 \\
\text { dias }\end{array}$ \\
\hline \multirow{6}{*}{ Cafeeiro } & 29 & 7 & $2,64 \pm 0,07 a^{2}$ & $1,38-4,18$ & Alaranjado \\
\hline & 1 & 7 & $2,17 \pm 0,05 b$ & $0,89-3,00$ & Avermelhado \\
\hline & 17 & 6 & $2,17 \pm 0,05 b$ & $1,30-2,99$ & Avermelhado \\
\hline & ССТ6756 & 6 & $1,94 \pm 0,05 \mathrm{c}$ & $1,00-3,72$ & Avermelhado \\
\hline & 32 & 7 & $1,18 \pm 0,02 d$ & $0,77-1,57$ & Alaranjado \\
\hline & 33 & 7 & $1,01 \pm 0,03 \quad \mathrm{e}$ & $0,51-1,54$ & Alaranjado \\
\hline \multirow{6}{*}{ Citros } & 34 & 8 & $1,26 \pm 0,02 d$ & $0,81-1,63$ & Avermelhado \\
\hline & 35 & 8 & $1,13 \pm 0,02 \mathrm{de}$ & $0,74-1,56$ & Avermelhado \\
\hline & 18 & 5 & $1,12 \pm 0,02 \mathrm{de}$ & $0,59-1,68$ & Avermelhado \\
\hline & 10 & 7 & $0,85 \pm 0,02$ & $0,57-1,16$ & Avermelhado \\
\hline & 37 & $5-6$ & $0,76 \pm 0,01$ & $0,57-1,08$ & Avermelhado \\
\hline & ССТ6570 & 5 & $0,73 \pm 0,02$ & $0,43-1,07$ & Avermelhado \\
\hline
\end{tabular}

${ }^{1}$ Erro padrão da média;

${ }^{2}$ Médias seguidas de mesma letra não diferem entre si, pelo teste Tukey $(\alpha<0,05)$.

No primeiro experimento, o isolado de citros CCT6570 apresentou o maior diâmetro médio de colônia $(0,90 \mathrm{~mm})$, seguido pelo isolado de cafeeiro $32(0,72 \mathrm{~mm})(\mathrm{F}$ = 7,64; $\mathrm{P}=$ 0,001) (Tabela 12). O diâmetro médio de colônias dos isolados de citros variou de 0,61 a $0,90 \mathrm{~mm}$ e dos isolados de cafeeiro, de 0,54 a 0,72 $\mathrm{mm}$.

No segundo experimento, ocorreu diferença significativa $(F=4,95 ; P=0,001)$ entre os isolados de cafeeiro, que em geral apresentaram os maiores diâmetros médios de colônia (1,01 a 2,64 mm) e os isolados de citros, que apresentaram diâmetros menores $(0,73$ a $1,26 \mathrm{~mm})$ (Tabela 13$)$.

Esses resultados mostram que tamanho de colônia é uma característica bastante variável entre experimentos com X. fastidiosa, mesmo padronizando-se os isolados, meio de cultura, número de passagens, tempo de crescimento e temperatura $\left(28^{\circ} \mathrm{C}\right)$, como foi feito neste estudo. O isolado CCT6756 (cafeeiro), por exemplo, apresentou diâmetro médio de colônia três vezes maior no $2^{\circ}$ experimento (Tabela 13) em relação ao $1^{\circ}$ (Tabela 12). Além disso, os intervalos de variação em diâmetro de colônias para 
cada isolado foram bastante elevados. Almeida et al. (2001) observaram que o diâmetro de colônia do isolado CCT6570 variou substancialmente $(0,46$ a 1,40 mm) dependendo do meio de cultura utilizado e do tempo de crescimento, sendo maior no PWG $(1,39$ $\mathrm{mm})$ em relação ao meio $\operatorname{BCYE}(0,43 \mathrm{~mm})$. $\mathrm{O}$ diâmetro de colônias da estirpe de cafeeiro, isoladas em meio SPW, variou de 0,50 a 1,50 mm (Lima et al., 1998).

Nos dois experimentos, o exame ao microscópio ótico (40 e 100 vezes) de colônias de isolados de citros, após 20 dias do plaqueamento, revelou a presença de filamentos semelhantes a exopolissacarídeos nos bordos das colônias (Figuras 15 e 16). As colônias dos isolados de cafeeiro, no primeiro e segundo experimentos (Figuras 17 e 18), apresentaram os bordos lisos. As colônias dos isolados de citros foram mais espessas e convexas, reduzindo a passagem de luz emitida pelo microscópio, principalmente as colônias do isolado 37 , cujos centros não puderam ser observados por serem escuros (Figura 15E). De um modo geral, as colônias dos isolados de cafeeiro foram mais facilmente focalizadas e observadas ao microscópio, por permitirem maior passagem de luz, apresentando formas mais abauladas com a coloração opalescente e margens lisas, enquanto que as de citros apresentaram-se mais convexas, com o centro áspero e margens finas e onduladas. Estas características dos isolados de citros e de cafeeiro são semelhantes às descritas originalmente para colônias de X. fastidiosa por Wells et al. (1987).

A presença de filamentos ao redor das colônias isoladas de citros pode ser uma influência do meio utilizado (PWG) (Purcell ${ }^{1}$ ), devendo ser investigada para um mesmo isolado em diferentes meios de cultura. Entretanto este é um aspecto fenotípico que deve ser levado em consideração para a caracterização das estirpes de $X$. fastidiosa, e que parece distinguir as estirpes de citros e cafeeiro. Tais filamentos foram observados em todos os isolados de citros e estiveram ausentes nos vários isolados de cafeeiro analisados no meio PWG.

\footnotetext{
${ }^{1}$ PURCELL, A.H. (Universidade da Califórnia). Comunicação pessoal, 2003.
} 
No primeiro experimento, somente para os isolados de citros, observou-se mudança na coloração do meio de cultura para um tom avermelhado, após 30 dias do plaqueamento (Figura 19). No segundo experimento, que incluiu um maior número de isolados, a mudança na coloração também foi observada em certos isolados de cafeeiro, indicando não ser esta uma característica específica dos isolados de X. fastidiosa de citros (Figura 20).

Deve-se salientar a necessidade de outros estudos com estes isolados, para verificar se as diferenças morfológicas observadas entre eles apresentam uma base genética (diferenças moleculares) e se têm implicações na virulência e na capacidade da bactéria em colonizar citros (estudos de patogenicidade). 


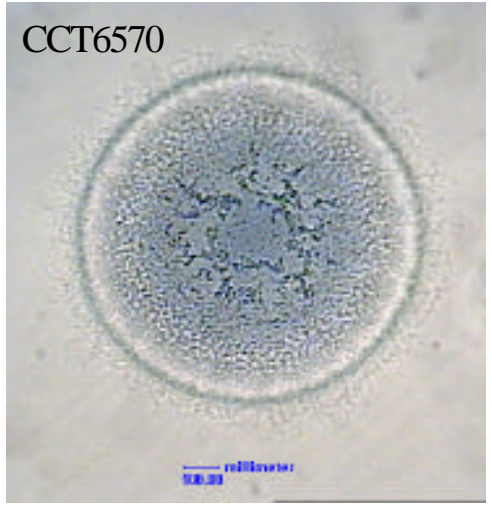

A

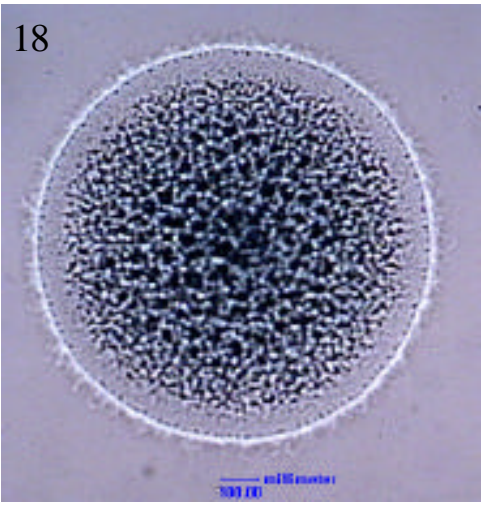

$\mathrm{C}$

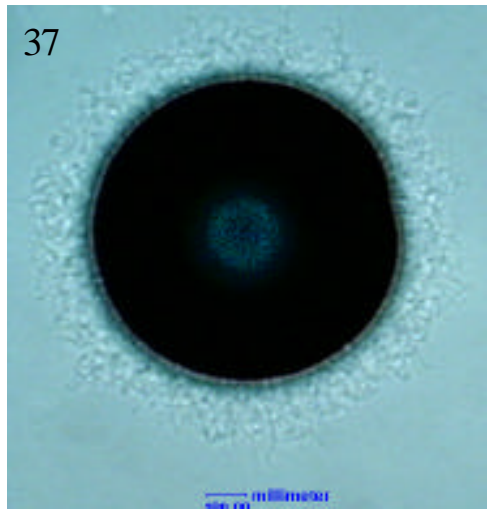

$\mathrm{E}$

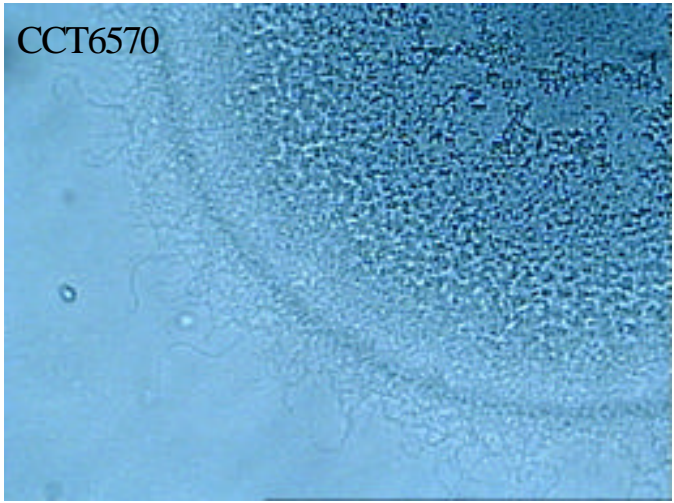

B

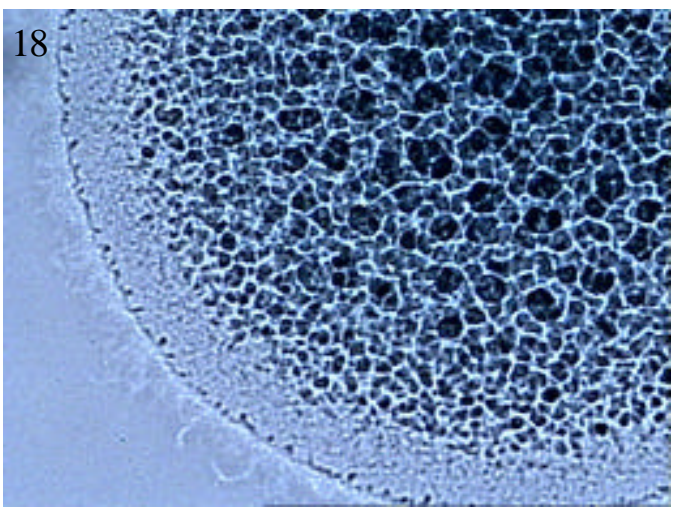

$\mathrm{D}$

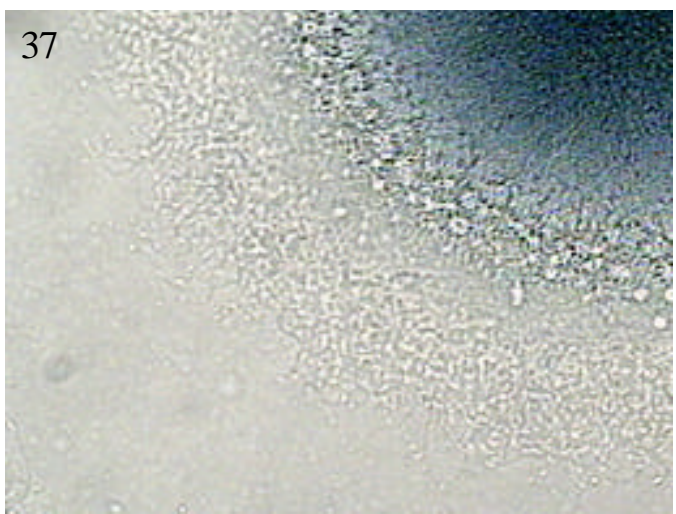

F

Figura 15 - Visualização através do microscópio ótico de uma unidade formadora de colônia da estirpe de citros de Xylella fastidiosa. Isolado CCT6570: aumento de 40X (A), e 100X (B); isolado 18: aumento de 40X (C), e 100X (D); e isolado 37: aumento de 40X (E) e 100X (F) 


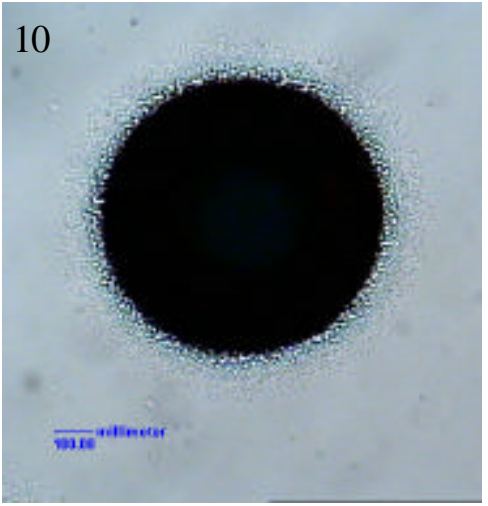

A

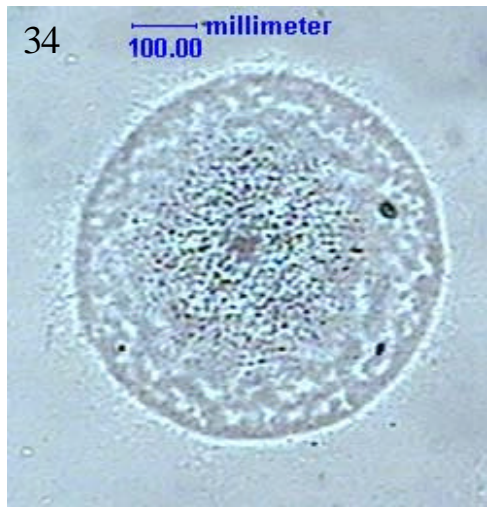

$\mathrm{C}$

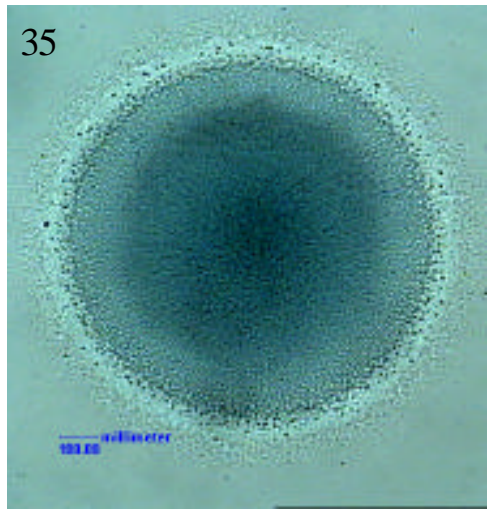

E

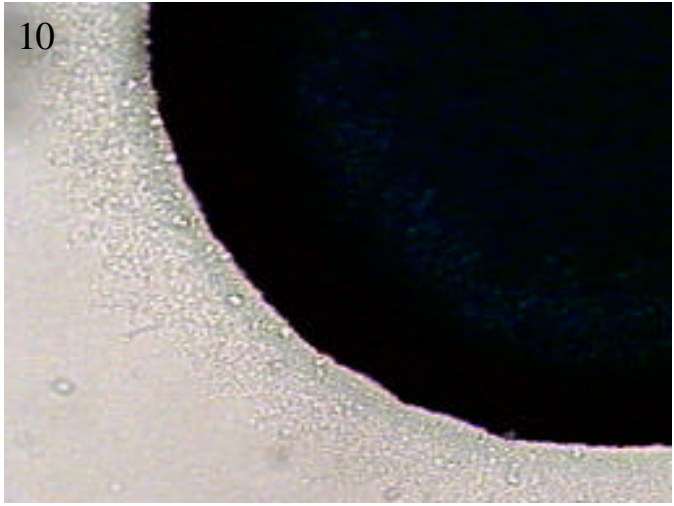

B

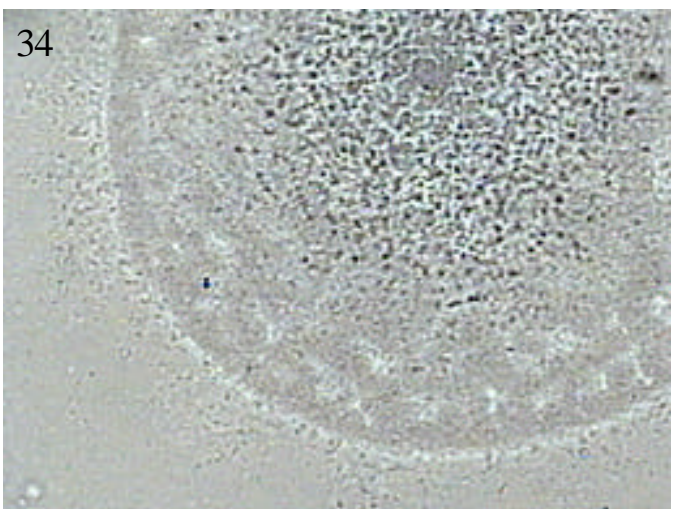

$\mathrm{D}$

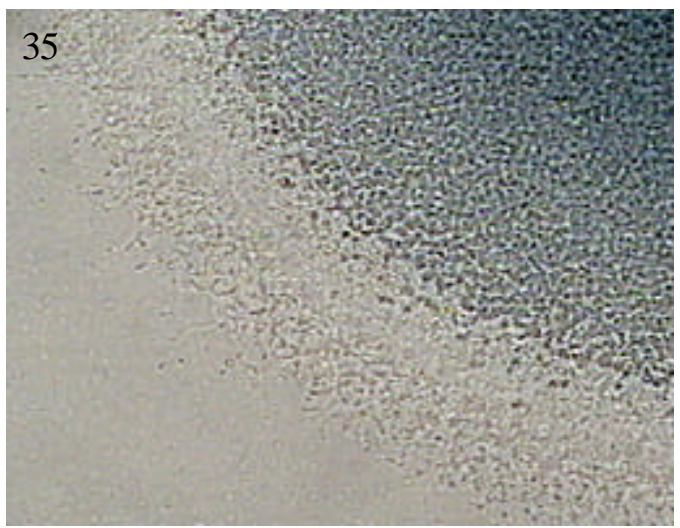

$\mathrm{F}$

Figura 16 - Visualização através do microscópio ótico de uma unidade formadora de colônia da estirpe de citros de Xylella fastidiosa. Isolado 10: aumento de 40X (A), e 100X (B); isolado 34: aumento de 40X (C), e 100X (D); e isolado 35: aumento de 40X (E) e 100X (F) 


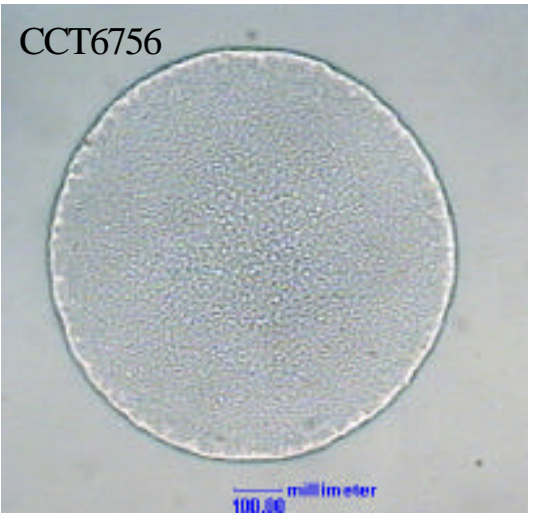

A

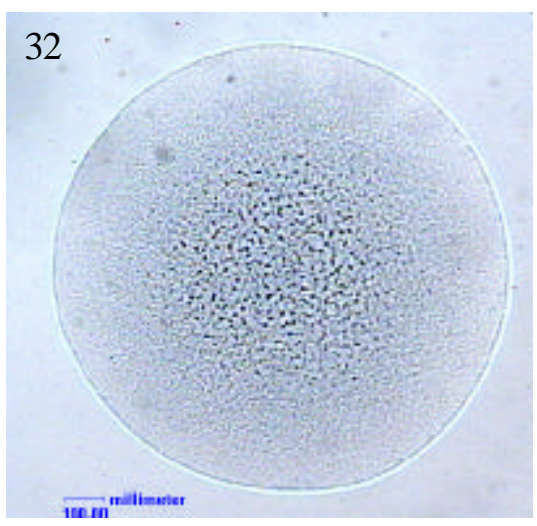

$\mathrm{C}$

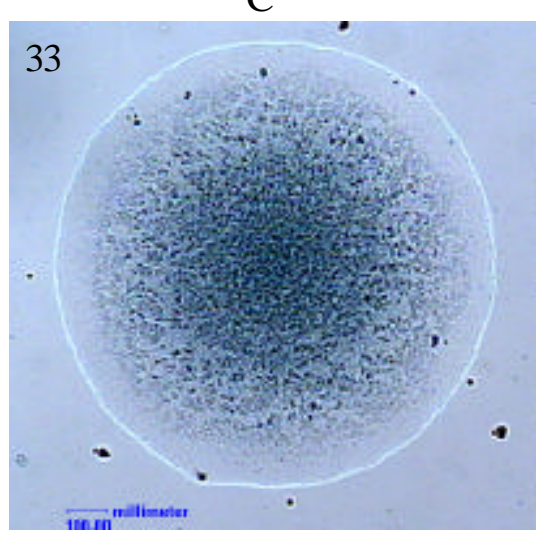

$\mathrm{E}$

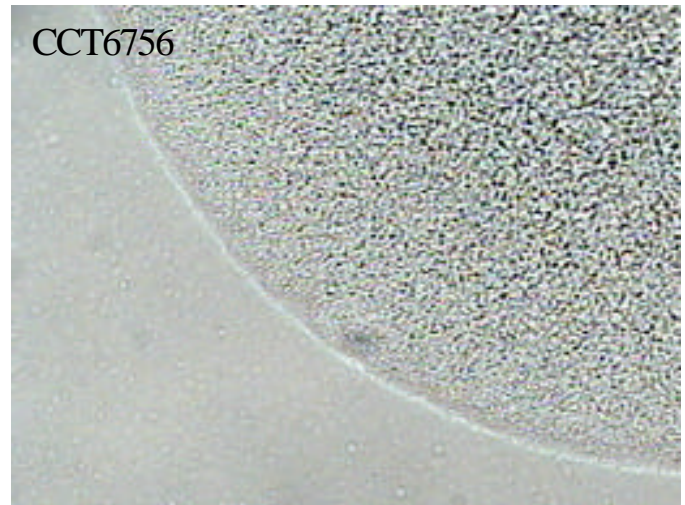

B

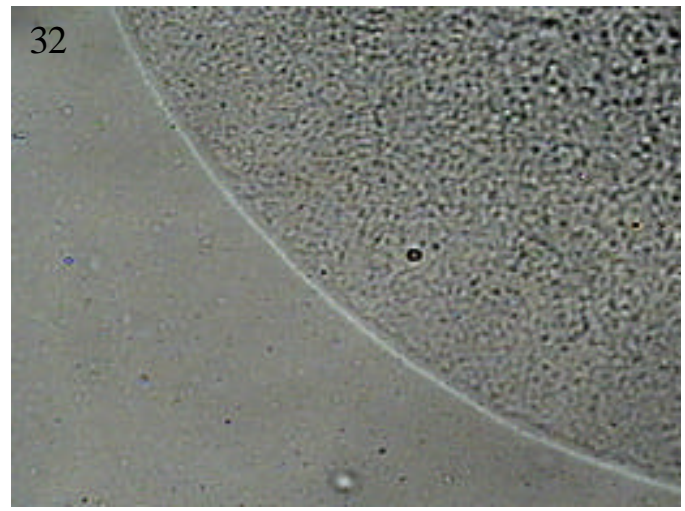

D

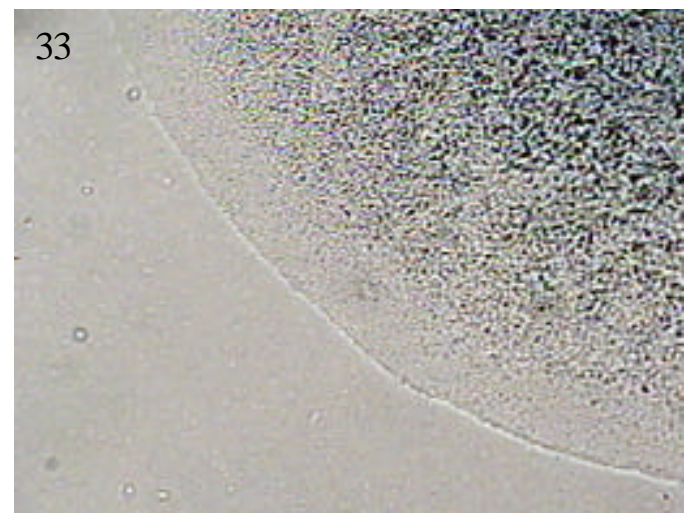

$\mathrm{F}$

Figura 17 - Visualização através do microscópio ótico de uma unidade formadora de colônia da estirpe de cafeeiro de Xylella fastidiosa. Isolado CCT6756: aumento de 40X (A), e 100X (B); isolado 32: aumento de 40X (C), e 100X (D); e isolado 33: aumento de 40X(E), e 100X (F) 


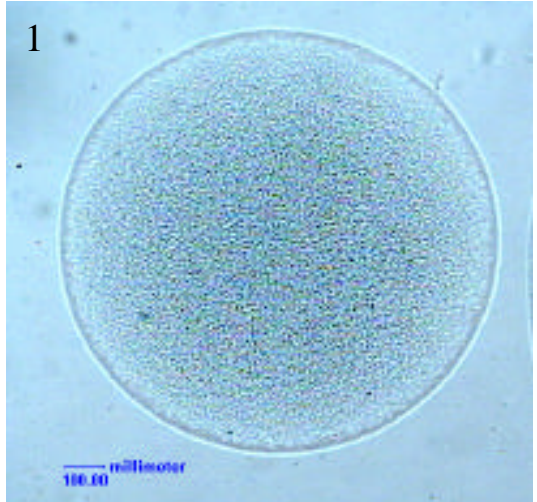

A

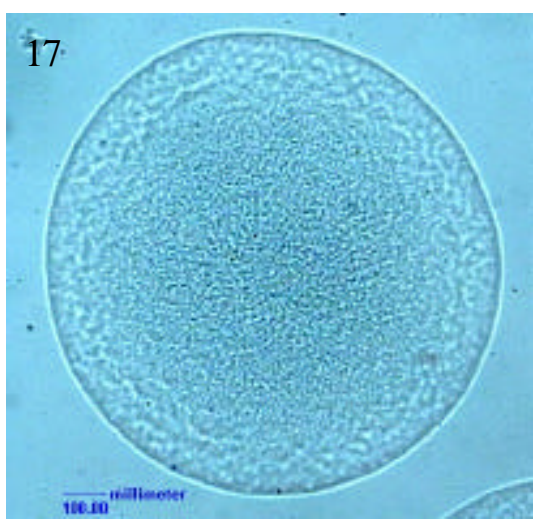

$\mathrm{C}$

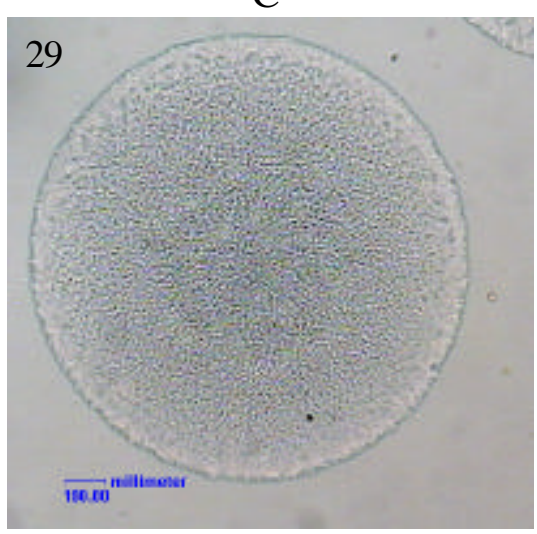

$\mathrm{E}$

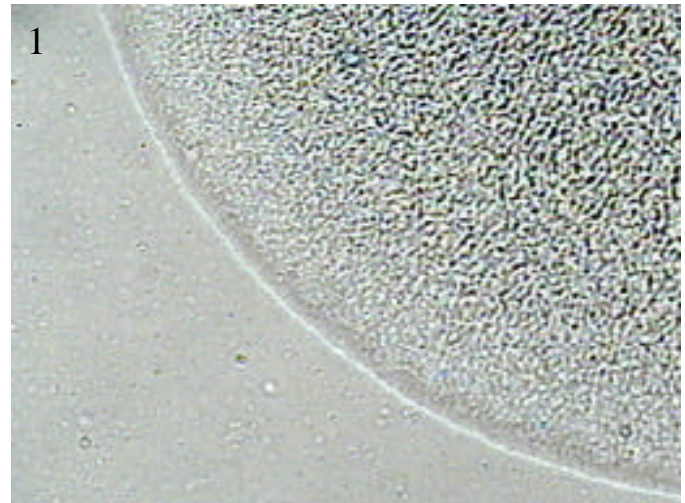

B

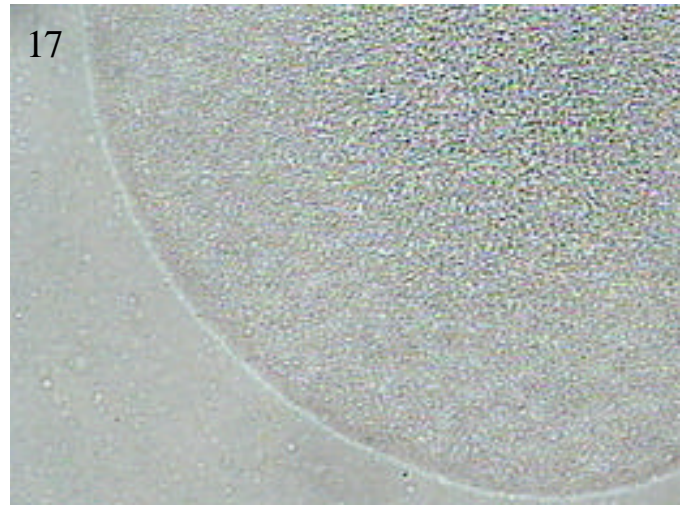

D

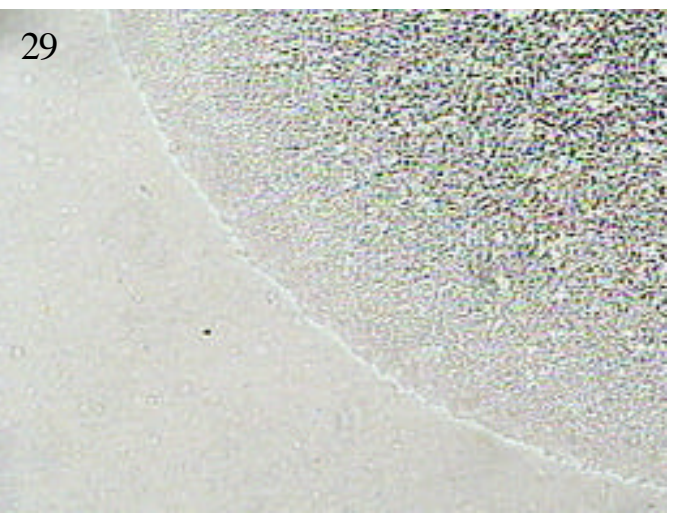

F

Figura 18 - Visualização através do microscópio ótico de uma unidade formadora de colônia da estirpe de cafeeiro de Xylella fastidiosa. Isolado 1: aumento de 40X (A), e 100X (B); isolado 17: aumento de 40X (C), e 100X (D); e isolado 29: aumento de 40X (E), e 100X (F) 


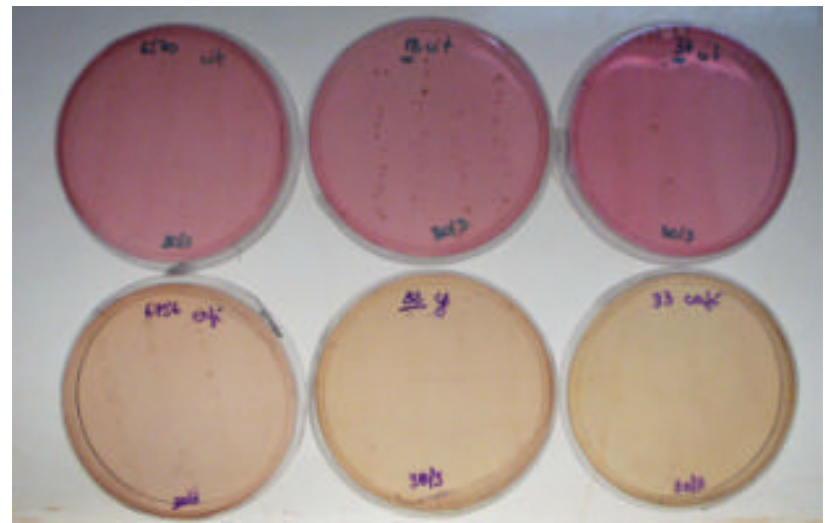

Figura 19 - Coloração do meio de cultura dos isolados de citros CCT6570, 18 e 37 após 30 dias do plaqueamento

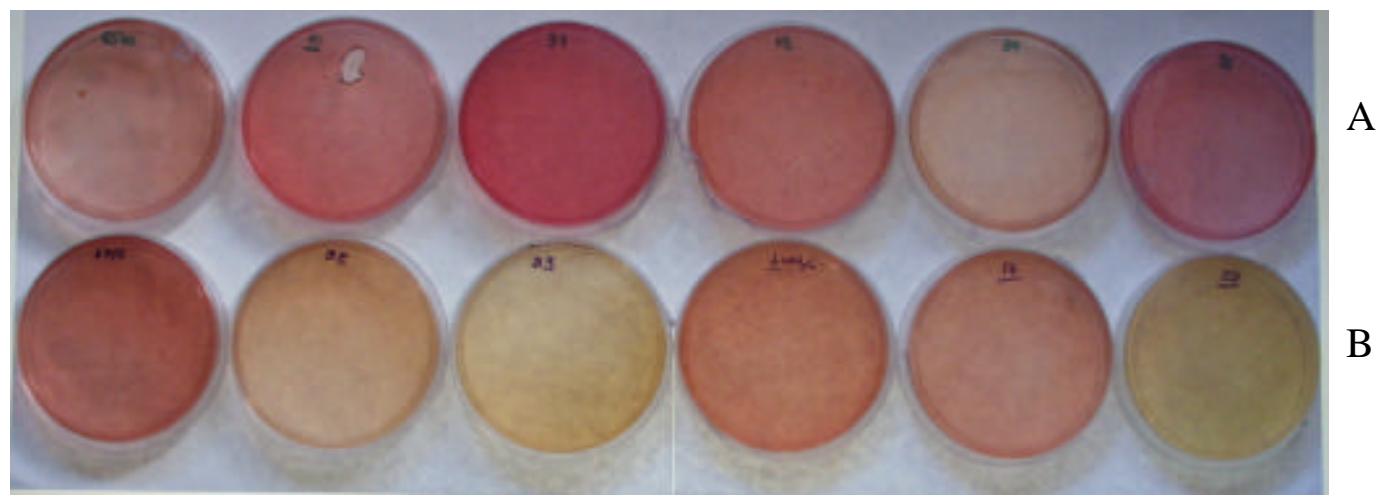

Figura 20 - Coloração do meio de cultura dos isolados de citros CCT 6570, 10, 37, 18, 34, 35 (A) e isolados de cafeeiro CCT 6756, 32, 33, 1, 17 e 29 (B) após 30 dias do plaqueamento 


\section{CONCLUSÕES}

$\checkmark$ Tecido de cafeeiro, quando homogeneizado com suspensão de células da estirpe de cafeeiro de Xylella fastidiosa, não inibiu o crescimento bacteriano após o plaqueamento da suspensão resultante em meio de cultura;

$\checkmark$ A estirpe de cafeeiro de X. fastidiosa não colonizou plantas de citros após inoculação por agulha, nas concentrações de inóculo avaliadas;

A inoculação por agulha da estirpe de citros de X. fastidiosa em cafeeiro result ou em baixas taxas de infecção, exigindo uma concentração de inóculo cerca de 10 vezes mais alta do que a necessária para a mesma taxa de infecção (25\%) em citros;

$\checkmark$ A estirpe de citros produziu maior concentração de células bacterianas cultiváveis em citros do que em cafeeiro;

$\checkmark$ No hospedeiro homólogo, a estirpe de cafeeiro apresentou doses efetivas mais baixas do que a estirpe de citros;

$\checkmark$ Não houve relação entre o diâmetro médio das colônias e o hospedeiro de origem dos isolados de $X$. fastidiosa;

$\checkmark$ Em meio de cultura PWG, os isolados de X. fastidiosa de citros distinguiram-se dos isolados de cafeeiro por apresentarem filamentos nos bordos das colônias. 


\section{REVISÃO BIBLIOGRÁFICA}

ALMEIDA, R.P.P.; PEREIRA, E.F.; PURCELL, A.H. et al. Multiplication and movement of a citrus strain of Xylella fastiosa within sweet orange. Plant Disease, v.85, n.4, p.382-386, 2001.

ALVES, E. Xylella fastidiosa adesão e colonização em vasos do xilema de laranjeira doce, cafeeiro, ameixeira, fumo e espécies de cigarrinhas vetoras e formação de biofilme sobre pelicula de poliestireno. Piracicaba, 2003. 122p. Tese (Doutorado) Escola Superior de Agricultura 'Luiz de Queiroz”, Universidade de São Paulo.

BANKS, D.; ALBIBI, R.; CHEN, J. Specific detection of Xylella fastidiosa Pierce's disease strains. Current Microbiology, v.39, p.85-88, 1999.

BARBOSA, J.F. Ocorrência e padrão espacial da atrofia dos ramos do cafeeiro (Xylella fastidiosa) nas regiões Sul e Zona da Mata de Minas Gerais. Lavras, 2003. 88p. Dissertação (Mestrado) - Universidade Federal de Lavras.

BERETTA, M.J.G.; LEE, R.F.; BARTHE, G.A. et al. Detection of Xylella fastidiosa in symptomless trees. In: CONFERENCE OF INTERNATIONAL ORGANIZATION OF CITRUS VIROLOGISTS, 12., New Delhi, 1993. Proceedings. New Delhi: IOCV, 1993. p.306-310.

BERETTA, M.J.G.; BARTHE, G.A.; CECCARDI, T.L. et al. A survey for strains of Xylella fastidiosa in citrus affected by citrus variegated chlorosis and citrus blight in Brazil. Plant Disease, v.81, n.10, p.1196-1198, 1997.

BERISHA, B.; CHEN, Y.D.; ZHANG, G.Y. et al. Isolation of Pierce's disease bacteria from grapevines in Europe. European Journal of Plant Pathology, v.104, p.427433, 1998.

CAMPANHARO, J.C.; LEMOS, M.V.F.; LEMOS, E.G.M. Growth optimization procedures for the phytopathogen Xylella fastidiosa. Current Microbiology, v.46, p.99-102, 2003. 
CARLOS, E.F.; CABRITA, J.R.M.; RODAS, V.Z. et al. Uso da poda em pomares com C.V.C. In: DONADIO, L.C.; MOREIRA, C.S. (Ed.). Clorose variegada dos citros. Bebedouro: Fundecitros, 1997. p.113-122.

CARVALHO, F.M.S.; MENEGUIM, L.; LEITE, R.P. Levantamento da distribuição de Xylella fastidiosa associada a Coffea spp, em regiões cafeeiras do Paraná. In: SIMPÓSIO DE PESQUISA DOS CAFÉS DO BRASIL, 1., Poços de Caldas, 2000. Resumos expandidos. Brasília: Embrapa, 2000. p.287-290.

CHAGAS, C.M.; ROSSETTI, V.; BERETTA, M.J.G. Electron-microscopy studies of a xylem-limited bacterium in sweet orange affected with citrus variegated chlorosis disease in Brazil. Journal of Phytopathology, v.134, p.306-312, 1992.

CHANG, C.J.; WALKER, J.T. Bacterial leaf scorch of northern red oak: isolation, cultivation and pathogenicity of a xylem-limited bacteria. Plant Disease, v.72, p.730-733, 1988.

CHANG, C.J.; DONALDSON, R.C. Xylella fastidiosa: Cultivation in chemically defined medium Phytopathology, v.83, n.2, p.192-194, 1993.

CHANG, C.J.; GARNIER, M.; ZREIK, L. et al. Culture and serological detection of the xylem-limited bacterium causing citrus variegated chlorosis and its identification as a strain of Xylella fastidiosa. Current Microbiology, v.27, p.137-142, 1993.

CHEN, J.; CHANG, C.J.; JARRET, R.L. et al. Genetic variation among Xylella fastidiosa strains. Phytopathology, v.82, n.9, p.973-977, 1992.

CHEN, J.; LAMIKANRA, O.; CHANG, C.J. et al. Randomly amplified polymorphic DNA analysis of Xylella fastidiosa Pierce's disease and oak leaf scorch pathotypes. Applied and Environmental Microbiology, v.61, p.1688-1690, 1995.

CHEN, J.; BANKS, D.; JARRET, R.L. et al. Use of 16S rDNA sequences as signature characters to identify Xylella fastidiosa. Current Microbiology, v.40, p.29-33, 2000 .

CHEN, J.; HARTUNG, J.S.; CHANG, C. et al. An evolutionary perspectiva of Pierce's disease of grapevine, citrus variegated clorosis, and mulberry leaf scorch diseases. Current Microbiology, v.45, p.423-428, 2002.

COLETTA FILHO, H.D. Diagnóstico molecular da bacteria Xylella fastidiosa. Biológico, v.61, n.2, p.51-53, 1999.

COLETTA FILHO, H.D.; MACHADO, M.A. Hospedeiros, transmissão e técnicas de diagnóstico da bactéria Xylella fastidiosa. Laranja, v.22, n.1, p.121-132, 2001. 
COLETTA FILHO, H.D.; MACHADO, M.A. Evaluation of the genetic structure of Xylella fastidiosa populations from different Citrus sinensis varieties. Applied and Environmental Microbiology, v.68, n.8, p.3731-3736, 2002.

COLETTA FILHO, H.D.; TAKITA, M.A.; SOUZA, A.A. et al. Differentiation of strains of Xylella fastidiosa by a variable number of tandem repeat analysis. Applied and Environmental Microbiology, v.67, n.9, p.4091-4095, 2001.

CONTRERAS, J. V. Pecosita ou falsa mancha grasienta na Argentina. Laranja \& Cia, v.31, p.6, 1992.

COSTA, P.I.; FRANCO, C.F.; MIRANDA, V.S. et al. Strains of Xylella fastidiosa rapidly distinguished by arbitrarily primed-PCR. Current Microbiology, v.40, p.279-282, 2000 .

DAVIS, M.J.; PURCELL, A.H.; THOMSON, S.V. Pierce's disease of grapevines: isolation of the causal bacterium. Science, v.199, p.75-77, 1978.

DAVIS, M.J.; THOMSON, S.V.; PURCELL, A.H. Etiological role of the xylem-limited bacterium causing Pierce's disease in almond leaf scorch. Phytopathology, v.70, n.6, p.472-475, 1980.

DAVIS, M.J.; FRENCH, W.J.; SCHAAD, N.W. Axenic culture of the bacteria associated with phony disease of peach and plum leaf scald. Current Microbiology, v.6, p.309-314, 1981.

DAVIS, M.J.; RAJU, B.C.; BRLANSKY, R.H. et al. Periwinkle wilt bacterium: axenic culture, pathogenicity, and relationships to other gram-negative, xylem-inhabiting bacteria. Phytopathology, v.73, p.1510-1515, 1983.

ERCOLANI, G.L. Infectivity titration with bacterial plant pathogens. Annual Review of Phytopathology, v.22, p.35-52, 1984.

FNP CONSULTORIA \& COMÉRCIO. Agrianual 2003: anuário da agricultura brasileira. São Paulo, 2003. p. 295-332: citrus.

FRAZIER, N.W. Xylem viruses and their insect vectors. In: INTERNATIONAL CONFERENCE ON VIRUS AND VECTOR ON PERENIAL HOSTS, WITH SPECIAL REFERENCE TO VITIS, Davis, 1965. Proceedings. Davis: University of California, 1965. p.91-99.

FREITAG, J.H. Host range of Pierce's disease virus of grapes as determined by insect transmission. Phytopathology, v. 41, p.920-934, 1951. 
FRY, S.M.; MILHOLLAND, R.D. Multiplication and translocation of Xylella fastidiosa in petioles and stems of grapevine resistant, tolerant, and susceptible to Pierce's disease. Phytopathology, v.80, n.1, p.61-65, 1990.

GOHEEN, A.C.; NYLAND, G.; LOWE, S.K. Association of a rickettsia-like organism with Pierce's disease of grapevines and alfafa dwarf and heat therapy of the disease in grapevines. Phytopathology, v.63, p.341-345, 1973.

HARRISON, N.A.; DAVIS, MJ. Infectivity titrations of Clavibacter xyli subsp. xyli and sugarcane cultivars differing in susceptibility to ratoon stunting disease. Plant Disease, v.70, n.6, p.556-558, 1986.

HARTUNG, J.S.; BERETTA, M.J.G.; BRLANSKY, R.H. et al. Citrus variegated chlorosis bacterium: axenic culture, pathogenicity, and serological relationships with other strains of Xylella fastidiosa. Phytopathology, v.84, n.6, p.591-597, 1994.

HEARON, S.S.; SHERALD, J.L.; KOSTKA, S.J. Association of xylem-limited bacteria with elm, sycamore, and oak leaf scorch. Canadian Journal of Botany, v.58, p.1986-1993, 1980.

HENDSON, M.; PURCELL, A.H.; CHEN, D. et al. Genetic diversity of Pierce's disease strains and other pathotypes of Xylella fastidiosa. Apllied and Environmental Microbiology, v.67, n.2, p.895-903, 2001.

HENSON, J.M.; FRENCH, R. The polymerase chain reaction and plant disease diagnosis. Annual Revie w of Phytopathology, v.31, p.81-109, 1993.

HEWITT, W.B.; HOUSTON, B.R. Association of Piere's disease and alfafa dwarf in California. Plant Disease Reporter, v.25, p.475-476, 1941.

HILL, B.L.; PURCELL, A.H. Acquisition and retention of Xylella fastidiosa by an efficient vector, Graphocephala atropunctata. Phytopathology, v.85, n.2, p.209212, 1995a.

HILL, B.L.; PURCELL, A.H. Multiplication and movement of Xylella fastidiosa within grape and four other plants. Phytopathology, v.85, n.11, p.1368-1372, $1995 \mathrm{~b}$.

HILL, B.L.; PURCELL, A.H. Populations of Xylella fastidiosa in plants required for transmission by efficient vector. Phytopathology, v.87, n.12, p.1197-1201, 1997.

HOLBEN, W.E.; JANSSON, J.K.; CHELM, B.K. DNA probe method for the detection of specific microorganisms in the soil bacterial community. Applied and Environmental Microbiology, v.54, n.3, p.703-711, 1988. 
HOPKINS, D.L. Physiological and pathological characteristics of virulent and avirulent strains of the bacterium that causes Pierce's disease of grapevine. Phytopathology, v.75, p.713-717, 1985.

HOPKINS, D.L. Xylella fastidiosa: xylem-limited bacterial pathogen of plants. Annual Review of Phytopathology, v.27, p.271-290, 1989.

HOPKINS, D.L.; ADLERZ, W.C. Natural hosts of Xylella fastidiosa in Florida. Plant Disease, v.72, n.5, p.429-431, 1988.

HOPKINS, D.L.; MOLLENHAUER, H.H. Rickettsia-like bacterium associated with Pierce's disease of grapes. Science, v.179, p.298-300, 1973.

HOPKINS, D.L.; PURCELL, A.H. Xylella fastidiosa: cause of Pierce's disease of grapevine and other emergent diseases. Plant Disease, v.86, n.10, p.1056-1066, 2002.

HOPKINS, D.L.; BISTLINE, F.W.; RUSSO, L.W. et al. Seasonal fluctuation in the occurrence of Xylella-Fastidiosa in root and stem extracts from citrus with blight. Plant Disease, v.75, n.2, p.145-147, 1991.

HUANG, G.F.; CHIARADIA, L.A. Clorose variegada dos citros: caracterização e alternativas no manejo da doença. Agropecuária Catarinense, v.11, n.4, p.52-55, 1998.

JINDAL, K.K.; SHARMA, R.C. Outbreaks and new records: India almond leaf scorch a new disease from India. FAO Plant Protection Bulletin, v.35, p.64-65, 1987.

KAMPER, S.M.; FRENCH, W.J.; DE KLOET, S.R. Genetic relationships of some fastidius xylem-limited bacteria. International Journal of Systematic Bacteriology, v.35, p.185-188, 1985.

KITAJIMA, E.W.; BAKARCIC, M.; FERNANDEZ-VALIEGA, M.V. Association of rickettsia like bacteria with plum leaf scald disease. Phytopathology, v.65, p.476479, 1975.

KITAJIMA, E.W.; MOHAN, S.K.; TSUNETA, M. et al. Ocorrência da escaldadura das folhas da ameixa nos Estados do Paraná e Santa Catarina. Fitopatologia Brasileira, v.6, n.2. p.285-292, 1981.

KRÜGNER, R.; LOPES, M.T.V. de C.; SANTOS, J. S. et al. Transmission efficiency of Xylella fastidiosa to citrus by sharpshooters and identification of two new vector species. In: CONFERENCE OF INTERNATIONAL ORGANIZATION OF CITRUS VIROLOGISTS, 14., Campinas, 2000. Proceedings. Riverside: IOCV, 2000. p. 423. 
LACAVA, P.T. Isolamento, caracterização genética por RAPD e resistência a antibióticos em Xylella fastidiosa. Piracicaba, 2000. 108p. Dissertação (Mestrado) Escola Superior de Agricultura 'Luiz de Queiroz”, Universidade de São Paulo.

LARANJEIRA, F.F. Dinâmica espacial e temporal da clorose variegada dos citros. Piracicaba, 1997. 144p. Dissertação (Mestrado) - Escola Superior de Agricultura "Luiz de Queiroz", Universidade de São Paulo.

LARANJEIRA, F.F.; BERGAMIN FILHO, A.; AMORIM, L. et al. Aspectos práticos da epidemiologia da clorose variegada dos citros. Revista Laranja, v.19, n.1, p.79-90, 1998.

LEE, R.F.; BERETTA, M.J.G.; HARTUNG, J.H. et al. Citrus variegated chlorosis: confirmation of Xylella fastidiosa as the causal agent. Summa Phytopathologica, v.19, n.2, p.123-125, 1993.

LEITE, R.M.V.B.C.; LEITE JÚNIOR, R.P.; CERESINI, P.C. Hospedeiros alternativos de Xylella fastidiosa entre plantas invasoras de pomares de ameixeira com escaldadura da folha. Fitopatologia Brasileira, v.22, n.1, p.54-57, 1997.

LEITE JÚNIOR, R.P.; LEITE, R.M.V.B.C. Associação de Xylella fastidiosa com clorose variegada do citros. Summa Phytopathologica, v.17, p.7, 1991.

LEITE JÚNIOR, R.P.; LEITE, R.M.V.B.C.; CERESINI, P.C. Ausência de patogenicidade de Xylella fastidiosa da escaldadura da folha da ameixeira na cultivar de pessegueiro Flordasun. Pesquisa Agropecuária Brasileira, v.33, n.10, p.1653-1660, 1998.

LEITE JÚNIOR, R.P.; SANTOS FILHO, H.P.; BARBOSA, C.J. et al. Constatação da clorose variegada dos citros causada por Xylella fastidiosa no Estado do Sergipe. Summa Phytopathologica, v.22, n.1, p.65, 1996.

LEU, L.S.; SU, C.C. Isolation, cultivation and pathogenicity of Xylella fastidiosa, the causal bacterium of pear leaf scorch disease in Taiwan. Plant Disease, v.77, n.6, p.642-646, 1993.

LI, W.B.; PRIA JÚNIOR, W.D.; TEIXEIRA, D.C. et al. Coffee leaf scorch caused by a strain of Xylella fastidiosa from citros. Plant Disease, v.85, n.5, p.501-505. 2001.

LI, W.B.; ZHOU, C.H.; PRIA JÚNIOR, W.D. et al. Citrus and coffee strains of Xylella fastidiosa induce Pierce's disease in grapevine. Plant Disease, v.86, n.11, p.12061210, 2002. 
LIMA, J. E. O.; MIRANDA, V.S.; COUTINHO, A. et al. Distribuição de Xylella fastidiosa no cafeeiro, nas regiões cafeeiras, $\mathrm{e}$ seu isolamento in vitro. Fitopatologia Brasileira, v.21, n.3, p.392-393, 1996.

LIMA, J.E.O.; MIRANDA, V.S.; HARTUNG, J.S. et al. Coffee leaf scorch bacterium: axenic culture, pathogeniticy, and comparison with Xylella fastidiosa of citrus. Plant Disease, v.82, n.1, p. 94-97, 1998.

LOPES, J.R.S. Mecanismos de transmissão de Xylella fastidiosa por cigarrinhas. Revista Laranja, v.17, p.79-92, 1996.

LOPES, J.R.S.; BERETTA, M.J.G.; HARAKAVA, R. et al. Confirmação da transmissão por cigarrinhas do agente causal da clorose variegada dos citros, Xylella fastidiosa. Fitopatologia Brasileira, v.21, p.343, 1996. Suplemento./Apresentado ao 29. Congresso Brasileiro de Fitopatologia, Campo Grande, 1996 - Resumo/

LOPES, J.R.S.; GIUSTOLIN, T.A.; MARUCCI, R.C. et al. Composição de espécies de cigarrinhas (Hemiptera, Auchenorrhyncha) em café e citros na região de Bebedouro, SP. In: CONGRESSO BRASILEIRO DE ENTOMOLOGIA, 17., Rio de Janeiro, 1998. Resumos. Rio de Janeiro: UFRJ, 1998. p.615.

LOPES, S.A.; DAMANN, K.E.; HOY, J.W. et al. Infectivity titration for assessing resistance to leaf scald among sugarcane aultivars. Plant Disease, v.85, n.6, p.592596, 2001.

LOPES, S.A.; MARCUSSI, S.; TORRES, S.C.Z. et al. Weeds as alternative hosts of the citrus, coffee, and plum strains of Xylella fastidiosa in Brazil. Plant Disease, v.87, n.5, p.544-549, 2003.

LOPES, S.A.; RIBEIRO, D.M.; ROBERTO, P.G. et al. Nicotiana tabacum as an experimental host for the study of plant - Xylella fastidiosa interactions. Plant Disease, v.84, n.8, p.827-830, 2000.

MAGALHÃES, M.N.; LIMA, A.C.P. de. Noções de probabilidade e estatística. São Paulo: EDUSP, 2002. 392p.

MARUCCI, R.C. Eficiência de transmissão de Xylella fastidiosa por cigarrinhas (Hemiptera, Cicadellidae) em Citrus sinensis (L.) Osbeck e Coffea arabica L. Piracicaba, 2003. 139p. Tese (Doutorado) - Escola Superior de Agricultura "Luiz de Queiroz", Universidade de São Paulo.

MARUCCI, R.C; GIUSTOLIN T.A.; MIRANDA, M.P. et al. Identification of a nonhost plant of Xylella fastidiosa to rear healthy sharpshooter vectors. Scientia Agricola, v.60, n.4, Oct/Dec. 2003. / No prelo 
MATIELLO, J.B.; ALMEIDA, S.R.; GARCIA, A.W.R. et al. Levantamento da ocorrência do amarelinho em regiões cafeeira do Brasil e primeira constatação em cafeeiros Conillon. In: CONGRESSO BRASILEIRO DE CAFEICULTURA, 23., Poços de Caldas, 1998. Resumos . Poços de Caldas: Embrapa, 1998. p.2.

MEHTA, A.; ROSATO, Y.B. Phylogenetic relationships of Xylella fastidiosa strains from different hosts, based on 16S rDNA and 16S-23S intergenic spacer sequence. International Journal of Systematic and Evolutionary Microbiology, v.51, p.311-318, 2001.

MILLER, S.A.; JOAQUIM, T.R. Diagnostic techniques for plant pathogens. In: CHET, I. (Ed.). Biotechnology in plant disease control. New York: Wiley-Liss, 1993. p.321-339.

MINSAVAGE, G.V.; THOMPSON, C.M.; HOPKINS, D.L. et al. Development of a polymerase chain reaction protocol for detection of Xylella fastidiosa in plant tissue. Phytopathology, v.84, p.456-461, 1994.

MIRCETICH, S.M.; LOWE, S.K.; MOLLER, W.J. et al. Etiology of almond leaf scorch disease and transmission of the causal agent. Phytopathology, v.66, p.17-24, 1976.

MIZUBUTI, E.S.G.; MATSUOKA, K.; PARIZZI, P. Associação de bactéria do tipo Xylella em laranjeiras com sintomas de clorose variegada na região da Zona da Mata de Minas Gerais. Fitopatologia Brasileira, v.19, n., p.241-244, 1994.

MOLLENHAUER, H.H.; HOPKINS, D.L. Xylem morphology of Pierce's diseaseinfected grapevines with different levels of tolerance. Physiological Plant Pathology, v.9, p.95-100, 1976.

MONTEIRO, P.B.; RENAUDIN, J.; JAGOUEIX-EVEILLARD, S. et al. Catharanthus roseus, an experimental host plant for the citrus strain of Xylella fastidiosa. Plant Disease, v.85, n.3, p.246-251, 2001.

NELDER, J.A.; WEDDERBURN, R.W.M. Generalized linear models. Journal of the Royal Statistical Society, Series A, v.135, p.370-384, 1972.

PAIÃO, F.G.; LEITE JÚNIOR., R.P. Otimização da técnica de PCR para detecção de Xylella fastidiosa em insetos vetores associados a cafeeiro. In: SIMPÓSIO DE PESQUISA DOS CAFÉS DO BRASIL, 2., Vitória, 2001. Resumos. Vitória: Embrapa, 2001. p.82.

PAIÃO, F.G.; MENEGUIM, A.M.; CASAGRANDE, E.C. et al. Envolvimento de cigarras (Homoptera, Cicadidae) na transmissão de Xylella fastidiosa em cafeeiro. Fitopatologia Brasileira, v.27, p.67, 2002. Suplemento./Apresentado ao 35. Congresso Brasileiro de Fitopatologia, Recife, 2002 - Resumo/ 
PARADELA FILHO, O.; SUGIMORI, M.H.; RIBEIRO, I.J.A. et al. Primeira constatação em cafeeiro no Brasil da Xylella fastidiosa causadora da clorose variegada dos citros. Laranja, v.16, n.2, p.135-136, 1995.

PARADELA FILHO, O.; SUGIMORI, M.H.; RIBEIRO, I.J.A. et al. Constatação de Xylella fastidiosa em cafeeiro no Brasil. Summa Phytopathologica, v. 23, n.1, p.46-49, 1997.

PEREIRA, E.F. Estudo de fatores sazonais relacionados à transmissão de Xylella fastiodiosa em pomares de citros. Piracicaba, 2000. 82p. Dissertação (Mestrado) Escola Superior de Agricultura 'Luiz de Queiroz”, Universidade de São Paulo.

PINTO, F.G.S.; LEITE JÚNIOR, R.P. Detecção de Xylella fastidiosa em Coffea spp através da técnica de PCR. Fitopatologia Brasileira, v.24, p.254, 1999. Suplemento./Apresentado ao 32. Congresso Brasileiro de Fitopatologia, Curitiba, 1999 - Resumo/

POOLER, M.R.; HARTUNG, J.S. Specific PCR detection and identification of Xylella fastidiosa strains causing citrus variegated chlorosis. Current Microbiology, v.31, p.377-381, 1995.

POOLER, M.R.; HARTUNG, J.S.; FENTON, R.G. Genetic relationships among strains of Xylella fastidiosa from RAPD-PCR data. Current Microbiology, v.31, p.134 137, 1995.

POOLER, M.R.; MYUNG, I.S.; BENTZ, J. et al. Detection of Xylella fastidiosa in potencial insect vectors by immunomagnetic separation and nested polymerase chain reaction. Letters in Applied Microbiology, v.25, p.123-126, 1997.

PRADO, J.R.A. Sanidade vegetal: quem diria, Xylella fastidiosa sempre esteve no café. A Granja, v.56, n.614, p.40-43, 2000.

PURCELL, A.H. Cigarrinhas na cultura de citros. In: SEMINÁRIO INTERNACIONAL DE CITROS, 3., Bebedouro, 1994. Anais. Campinas: Fundação Cargill, 1994. p.195-209.

PURCELL, A.H.; FINLAY, A.H. Evidence for noncirculative transmission of Pierce's disease bacterium by sharpshooter leafhoppers. Phytopathology, v.69, p.393-395, 1979.

PURCELL, A.H.; HOPKINS, D.L. Fastidious xylem-limited bacterial plant pathogens. Annual Review of Phytopathology, v.34, p.131-151, 1996. 
PURCELL, A.H.; SAUNDERS, S.R. Fate of Pierce's disease strains of Xylella fastidiosa in common riparian plants in California. Plant Disease, v.83, p.825-830, 1999.

PURCELL, A.H.; SAUNDERS, S.R.; HENDSON, M. et al. Causal role of Xylella fastidiosa in oleander leaf scorch disease. Phytopathology, v.89, n.1, p.53-58, 1999.

QIN, X.; MIRANDA, V.S.; MACHADO, M.A. et al. An evaluation of the genetic diversity of Xylella fastidiosa isolated from diseased citrus and coffee in São Paulo, Brazil. Phytopathology, v.91, n.6, p.599-605, 2001.

RAIO X da citricultura. Revista do Fundecitrus, v.11, n.110, p.10-11, maio/jun. 2002.

RAJU, B.C.; WELLS, J.M.; NYLAND, G. et al. Plum leaf scald: isolation, culture, and pathogenicity of the causal agent. Phytopathology, v.72, n.11, p.1460-1466, 1982.

RAJU, B.C.; GOHEEN, A.C.; FRAZIER, N.W. Occurrence of Pierce's disease bacteria in plants and vectors in California. Phytopathology, v.73, p.1309-1313, 1983.

ROBERTO, S.R.; COUTINHO, A.; LIMA. et al. Transmissão de Xylella fastidiosa pelas cigarrinhas Dilobopterus costalimai, Acrogonia terminalis e Oncometopia facialis em citros. Fitopatologia Brasileira, v.21, n.4, p.517-518, 1996.

RODRÍGUEZ, C.M.; OBANDO, J.J.; VILLALOBOS, W. et al. First report of Xylella fastidiosa infecting coffee in Costa Rica. Plant Disease, v.85, p.1027. 2001.

ROSATO, Y.E; NETO, J.R.; MIRANDA, V.S. et al. Diversity of a Xylella fastidiosa population isolated from Citrus sinensis affected by citrus variegated chlorosis in Brazil. Sys tematic Applied Microbiology, v.21, p.593-598, 1998.

ROSSETTI, V.; GARNIER, M.B.; BOVÉ, J.M. et al. Présence de bactéries dans le xylème d'orangers atteints de chlorose variégée, une nouvelle maladie des agrumes au Brésil. Comptés Rendus de I' Académie des Sciences. Series 3 Sciences de la Vie, v.310, p.345-349, 1990.

SANDERLIN, R.S.; HEYDERICH-ALGER, K.I. Evidence that Xylella fastidiosa can cause leaf scorch disease of pecan. Plant Disease, v.84, n.12, p.1282-1286, 2000.

SANTOS FILHO, H.P.; BARBOSA, C.J.; MATRANGOLO, W.J.R. et al. Ocorrência da clorose variegada dos citros (CVC) no estado da Bahia. Fitopatologia Brasileira, v.24, n.2, p.190, 1999. 
SEMPIONATO, O.R.; GIROTTO, L.F.; STUCHI, E.S. Produção de mudas sadias. In: DONADIO, L.C.; MOREIRA, C.S. (Ed.). Clorose variegada dos citros. Bebedouro: Fundecitros, 1997. cap.5, p.75-92.

SEVERIN, H.H.P. Transmission of the virus of Pierce's disease by leafhoppers. Hilgardia, v.19, p.190-202, 1949.

SHERALD, J.L. Pathogenicity of Xylella fastidiosa in american elm and failure of reciprocal transmission between strains from elm and sycamore. Plant Disease, v.77, n.2, p.190-193, 1993.

TAKATSU, A.; SANTOS, M.R.; MALUF, R.C. Xylella fastidiosa do cafeeiro no Triângulo Mineiro e Alto Paranaíba. In: SIMPÓSIO DE PESQUISA DOS CAFÉS DO BRASIL, 2., Vitória, 2001. Resumos. Vitória: Embrapa, 2001. p.1234-1241.

TURNER, W. F.; POLLARD, H.N. Life histories and behavior of five insect vectors of phony peach disease. Washington: USDA, 1959. 28p. (USDA. Technical Bulletin, 1188).

UCHIBABA, E.Y.; LEITE JÚNIOR, R.P.; LEITE, R.M.V.B.C. Avaliação de meios de cultura gerais e específicos para cultivo de Xylella fastidiosa isolada de ameixeira com escaldadura da folha. Fitopatologia brasileira, v.17, p.252-257, 1992.

WELLS, J.M.; RAJU, B.C.; NYLAND, G. et al. Medium for isolation and growth of bacteria associated with plum leaf scald and phony peach diseases. Applied and Environmental Microbiology, v.42, p.357-363, 1981a.

WELLS, J.M.; RAJU, B.C.; THOMSON, J.M. et al. Evidence of the common etiology of phony peach and plum leaf scald diseases. Phytopathology, v.71, p.1156-1161, $1981 b$.

WELLS, J.M.; RAJU, B.C.; NYLAND, G. Isolation, culture, and pathogenicity of the bacterium causing phony disease of peach. Phytopathology, v.73, n.6, p.859-862, 1983.

WELLS, J.M.; RAJU, B.C.; HUNG, H.Y. et al. Xylella fastidiosa gen. nov., sp. nov: Gram-negative, xylem-limited fastidious plant bacteria related to Xanthomonas spp. International Journal of Systematic Bacteriology, v.37, n.2, p.136-143, 1987.

WICHMAN, R.L.; HOPKINS, D.L. Differentiation of pathogenic groups of Xylella fastidiosa strains with whole-cell protein profiles. Plant Disease, v.86, n.8, p.875879, 2002. 
YAMAMOTO, P.T.; ROBERTO, S.R.; PRIA JÚNIOR, W.D. et al. Transmissão de Xylella fastidiosa por cigarrinhas Acrogonia virescens e Homalodisca ignorata (Hemiptera:Cicadellidae) em plantas cítricas. Summa Phytopathologica, v.28, n.2, p.178-181, 2002. 